\title{
إسهام جائزة التعليم للتميز في التنمية الذاتية لدى طلاب المرحلة الثانوية من وجهة نظر المحلمين بمحافظتي حوطة بني تمييم والحريق التئي
}

\section{سعر بن مباره بن سعر القريني}

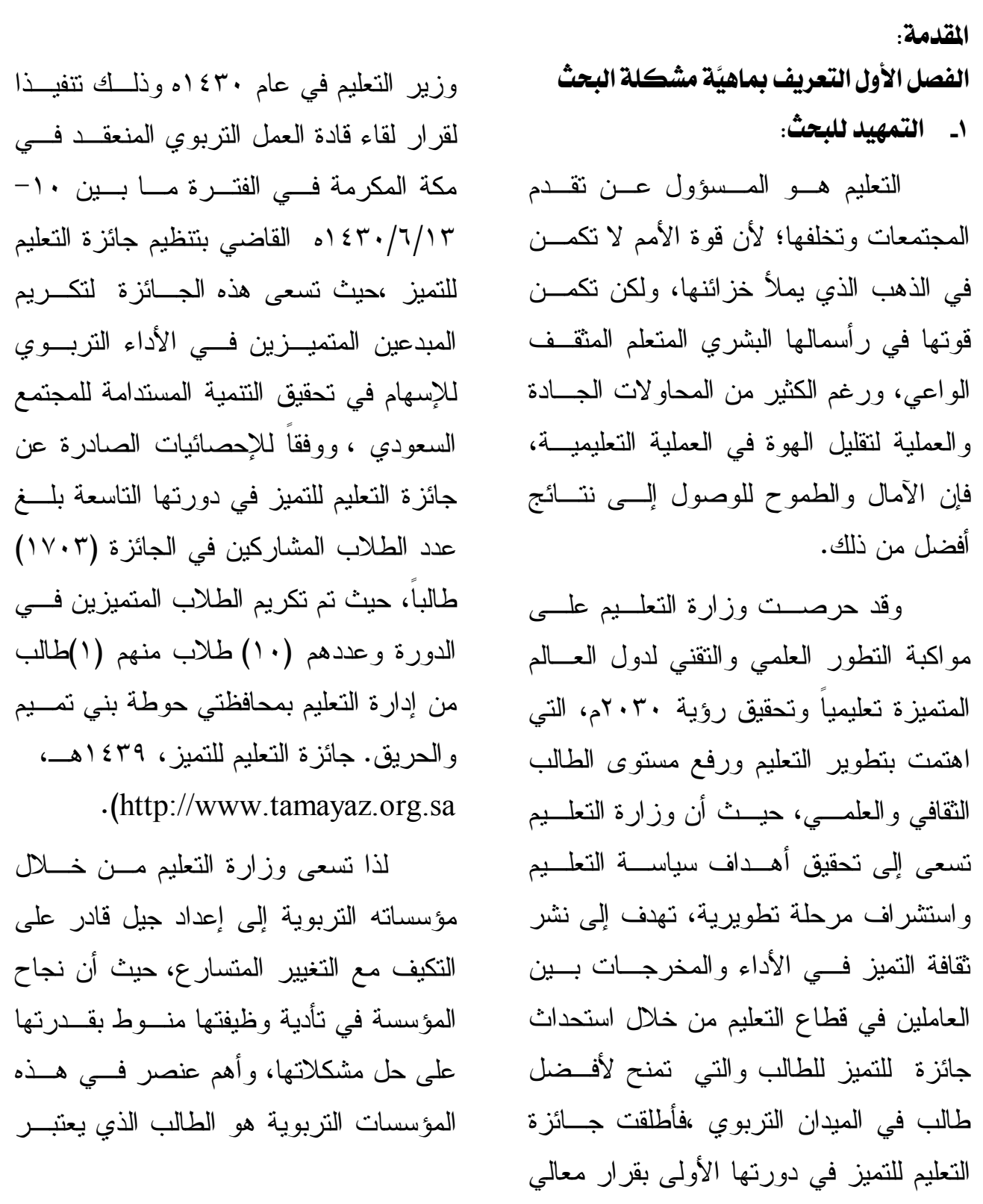




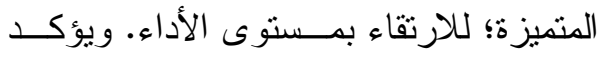

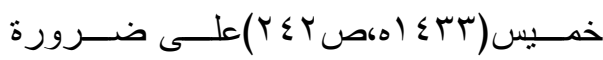

تحفيز المـتـعلم و ودفعه للتفكير مــن خــلهل

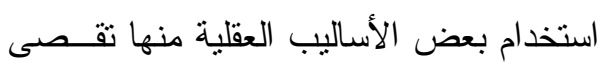

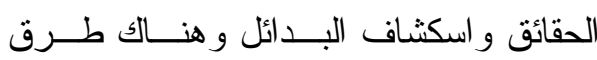
للتعلم التي اثتتت فاعلية كبيرة فى نتمية كثير

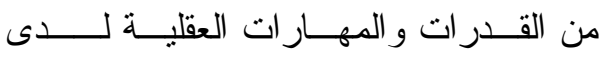

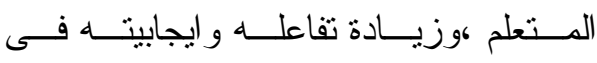

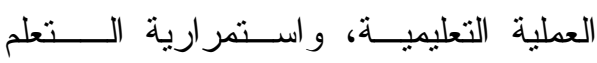

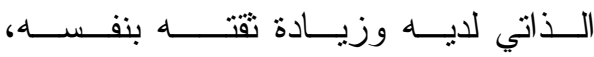

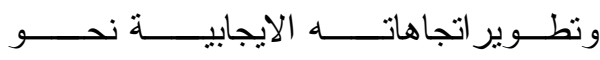

(Quintana, Krajcik موضــوع الــتعلم \& Soloway, 2013, p.118) وبما أن جائزة وزارة التعليم للتميـز

تهذف إلى تحفيز الطالب لتحقيــق المعرفــة

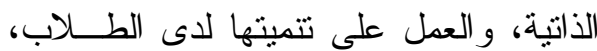
فمن المهم التعرف على إسهام هذه الجـائزة

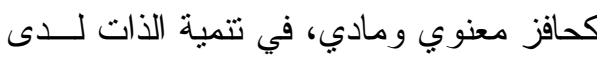

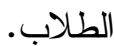

وتأكيداً على ما سبق تكمـن مــشكلة

الدراسة في الكثف عن إسهام جائزة التعليم للتميز في التتمية الذاتية لدى طلاب المرحلة الثانوية من وجهة نظر المعلمين بمحسـافظتي حوطة بني تميم و الحريق.

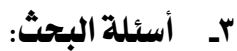

السؤال الرئيس: ما إبـــهام جـائزة

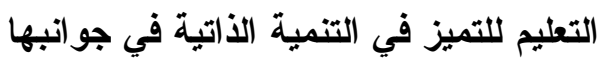

ركيزة أساسية في العملية التعليمية (خـاطر،

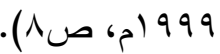

وتؤكد التربية الحديثة على الاهتـــام بتتمية شخصية الفرد مــن جميــع جوانبــه الجسدية، و العقلية، و الروحية، و الاجتماعية،

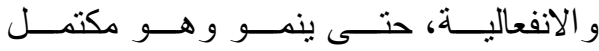
الثخصية، لذا بجب على المربي أن يتعرف وله

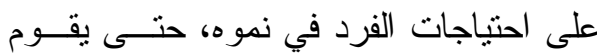

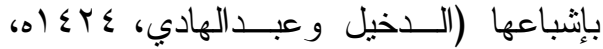

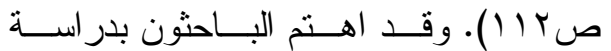
احتياجات الفرد في نموه ومن هذه الدراسات

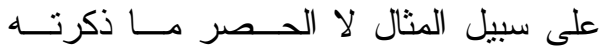

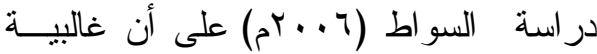

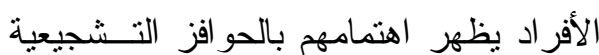
بدرجة عالية. r - التعريف بمشكلة البحث: لتسارع العصر المعلوماتي وتطـــوره و التغير الاجتماعي وحاجة الطالب لمواكبته، و لأهمية الطالب ودوره في العملية التعليمية،

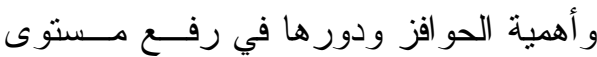
الطالب، سعت وزارة التعليم بالمملكة العربية

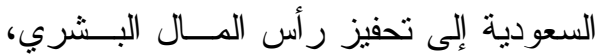
وتحسين وتطوير الأداء من خــله مر اكــز

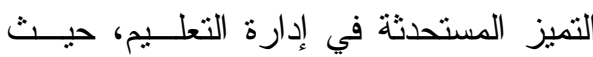

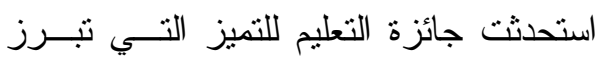
روح التتافس الإيجابي بين الطلاب؛ لتحقيــق

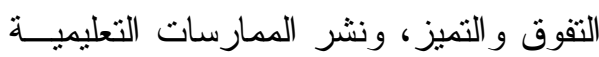




$$
\begin{aligned}
& \text { r- الوقوف على إسهام جـائزة التعلـــم } \\
& \text { الثلاث لاى طلاب المرحلة الثانويــة مسن } \\
& \text { للتميز في تتمية (التطلعات المهنيــة) } \\
& \text { لدى طلاب المرحلة الثانوية. } \\
& \text { ه- أهمية البحث: - n } \\
& \text { تكمن أهمية البحث فيما يلي: } \\
& \text { ا ـ ما إسهام جائزة التعليم للتمبز في تتمية أ) الأهميَّة العلميَّة (النظريَّة): }
\end{aligned}
$$

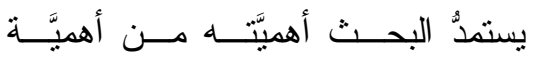

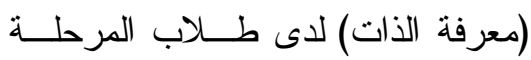

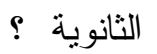

$$
\begin{aligned}
& \text { مساهمة جائزة التعليم للتميز، لتحفيـز } \\
& \text { جميع الطلاب في تنمية ذواتهم، الــذي }
\end{aligned}
$$

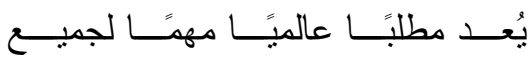

$$
\begin{aligned}
& \text { المؤسسات التعليمية للنطوير و التحسين. } \\
& \text { إلقائه الضوء على الطالب، ليكون قادراً }
\end{aligned}
$$

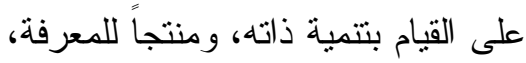

$$
\begin{aligned}
& \text { ومتعلماً مدى الحياة. }
\end{aligned}
$$

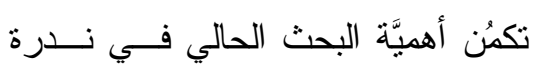

$$
\begin{aligned}
& \text { البحوث و الدّر استات، التي تناولت نتمية } \\
& \text { الذات لاى طلاب المرحلة الثانوية. }
\end{aligned}
$$

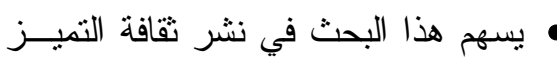

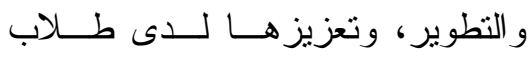

$$
\begin{aligned}
& \text { المرحلة الثانوية. } \\
& \text { ب) الأهميَّة العمليَّة (التطبيقيَّة): }
\end{aligned}
$$

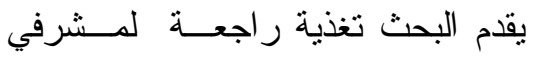

$$
\begin{aligned}
& \text { التوجيه و الإرشاد على الواقع الفعلـيـي لئي }
\end{aligned}
$$

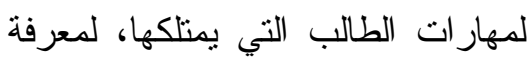

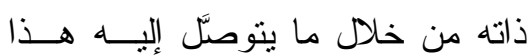

$$
\begin{aligned}
& \text { البحث من نتائج وتوصيات. } \\
& \text { وجهة نظر المعلمين بمحافظتي حوطة بني } \\
& \text { تميم و الحريث؟ } \\
& \text { وللإجابة عن السؤال الرئيس لابد من الإجابة } \\
& \text { عن الأسئلة الفرعية الآتية: } \\
& \text { r. ما إسهام جائزة التعليم للتميز في تتمية } \\
& \text { (تطوير الذات) لدى طـــلاب المرحلـــــة }
\end{aligned}
$$

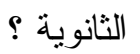

$$
\begin{aligned}
& \text { الثانوية؟ }
\end{aligned}
$$

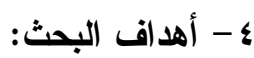


الممارسات المتميـزةة، و التفـــوق العلدــي،

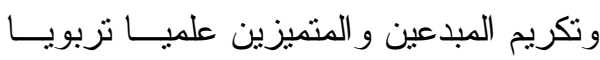

وإداريا، ونشر نقافة التميز و العمل للإتقــان"

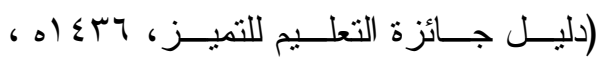

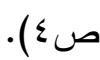

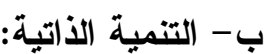

التعريف الإجرائي للتنمية الذاتيــة:

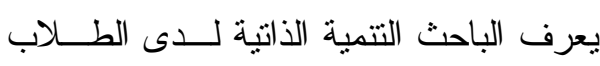

على أنها تطبيق لمجموعـــة مــن العناصــر

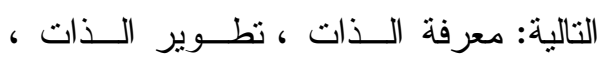

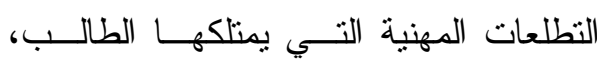

و العمل على تتميتها بأساليب منتوعة، ليكون

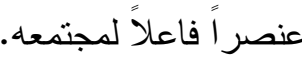

ج- معرفة الذات:

التعريف الإجر ائي لمعرفة الذات:

يعرف الباحث معرفة الــذات لــدى

الطلاب إجر ائياً بأنه ما يملكه الطالــب مــن لــن

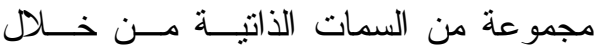

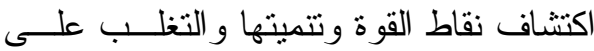

نقاط الضعف وتعزيز الثقة بالنفس وتتميتها.

د - تظوير الذات:

التعريف الإجر ائي لتطوير الذات:

يعرف الباحث تطوير الذات إجرائياً

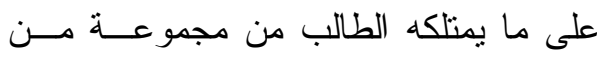

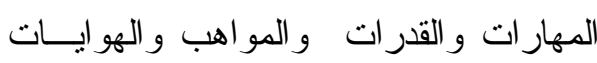

الإيجابية و العمل على تتميتها وتطوير ها.
يسهم البحث في دعم متخذي القــرار

للوقوف على جوانب القصور للجائزة،

كما قد يُسهم في تحسين الممارسات من جن خلال اكتشاف الذات لدى الطلاب.

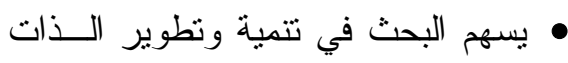

لجميع طلاب التعليم العام.

• يسهم البحث في نمو المعرفة والمهارة

و الخبرة المهنية لدى الطلاب.

$$
\text { 4 - حدود البحث: }
$$

أ - الحدود الموضوعية: اقتصر البحــث

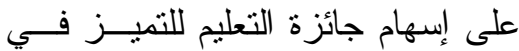

مجال التتمية الذاتيــة لــدى الطـــلاب

لتحقيق تمكن الطالب من معرفة ذاتـهـ

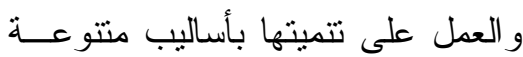

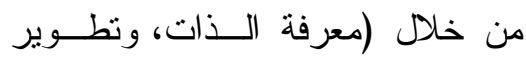

الذات، و التطلعات المهنية).

ب - الحدود المكانية: اقتصر البحث على

المرحلة الثانوية في محافظتي حوطـــة

$$
\text { بني تميم و الحريق (بنين). }
$$

ج- الحدود الزمانية: تم تطبيــق البحــث خلص الفصل الدراسي الأول من العام

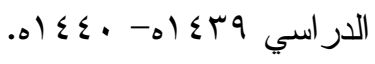

$$
\text { - V - Vصطلحات البحث: - V }
$$$$
\text { أ - أ - جائزة التعليم للتميز: }
$$

هي "منحة تحفيزيه للميدان التعليهـي

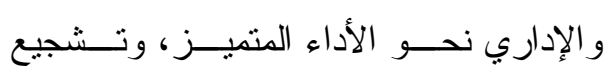


وزير التربية و التعليم سابقا (وزارة التعلــيم)

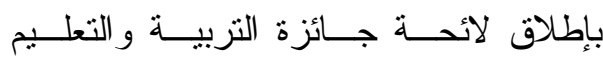

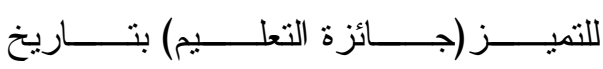
 وظهرت الجائزة نتيجة تعاون وشر اكة وطنية فكرية ومعرفية بين وزارة التعليم من جهة ، و الجمعية السعودية للعلوم التزبويــة و النفسية (جستن) من جهة أخرى.

وللجائزة دورة سنوية تبدأ مع بدايــة العام الدراسي وتتتهي قبل نهايته.

أنطلقت هذه الجائزة لتحقق مزيداً من عملية التحفيز ، حيث تعد هذه الحوافز مـن

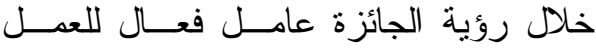
المؤسسي ، و الطريقة التي تعبر بها المؤسسة

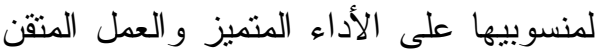

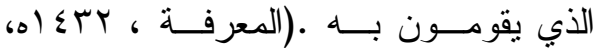

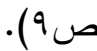
روئية الجائزة : الريادة العالمية لجوائز التميز التربوي

$$
\text { في عصر المعرفة . }
$$

الالرسالة:

تسعى الجائزة لتكــــيم لائــق لكــل

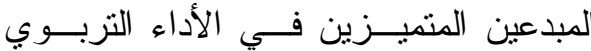
،لإسهام في تحقيق التتمية المستدامة للمجتمع لردين

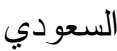

ه- التطلعات المهنية:

التعريف الإجرائي لتطلعات المهنية: يعرف الباحث التطلعات المهنية لدى الطلاب إجرائياً بأنها تعني ما بمتلكه الطالب من ميول نحو مهنة المستقبل وتحديد أهدافه المسنقبلية لتحقيقها.

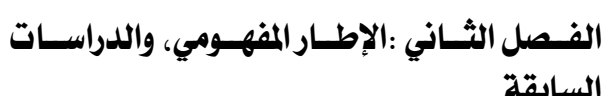

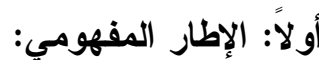
1- جائزة التعليم للتميز:

عرفت وزارة التعليم جائزة التعليم للتميز في دليل مطبوع اثتنمل على عدد من العناصــر هي: مقدمة: - مقي فــي إطــار الـسعي نحسـو تطـــوير المؤسسات التربوية في إحداث تتمية وطنية ،

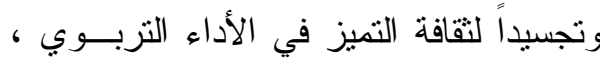
جاء إعلان وزارة التعليم في المملكة العربية السعودية عن تأسيس جائزة ســنوية للتميـز التربوي لجميع عناصر المنظومة التزبويــة و التعليمية .

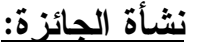

جاءت فكرة الجائزة بعد التوصية التي اتخذها قادة العمل التربوي في لقائهم الــذي عقد بمكة المكرمة عام •بـ اه ، ثم تحولت هذه التوصية إلى و اقع عندما صــدر قــرار 
Qawasmeh, ويعرفــهـ قو اســـمه

أهداف الجائزة:

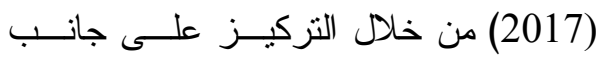

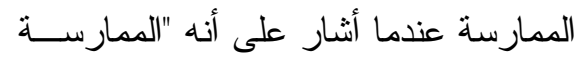

الباهرة في إدارة المنظمة و تحقيــق النتــائج المرجوة"(صنامة (10).

و عرفه السكارنه (ب ع اه) على أنــه

"فريد في النوع، وبديع و رائع، ووحيد مسن

شاكلته ويكون الأول" (صل VI (1).

ومن خلال ما أثنير إليه من المفاهيم

السابقة يتضح أن التميز بدل على أن الثيء

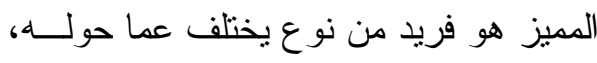

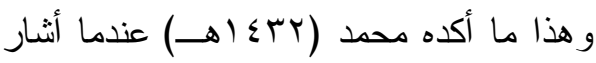

بأن الطالب يسعى دائهاً للأفضلية بين أقرانه،

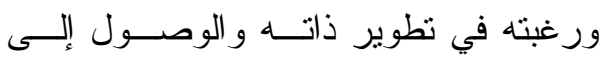

الهدف الذي يريد تحقيقه. (ص 9 (1).

ويضيف باثـــيوة (דrع 10) إلــى أن

ليس كل ما يفعله الآخرون اتباعه فقط، بـلـ

فعل أنثياء مختلفة ومفضلة، بحيث لا يكــون

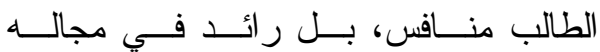

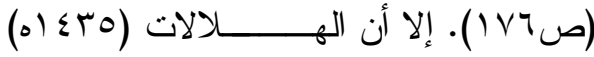
أضاف من خلال التزكيز على ما يكتـسبه الطالب ويحققه، عندما أثنار إلى أن "التميـز لإنز

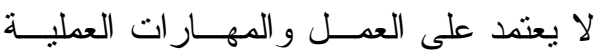

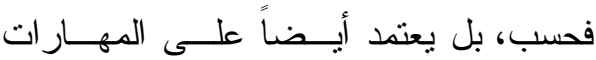

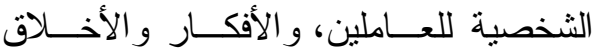
و المرونة....، وقدرتهم على التخطيط واتخاذ القرارات وتتفيذها". حيث أن التميز لا يعني وني ونهي

الهذف العام للجــائزة هــــ تـشجيع

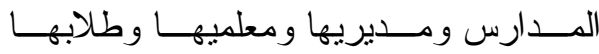
ومن لهم علاقة بالعملية التربويــة و إبــراز

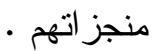

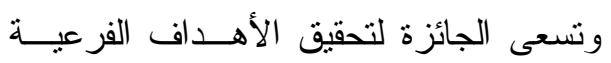

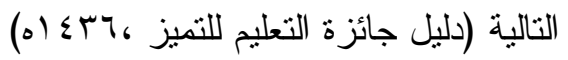
1- تشجيع التميز في التعليم العام. r- تقدير جميع فئات العمل التربوي . r- نشر ثقافة التميز ،و الإبداع ، و الإلتز ام ، و الإتقان.

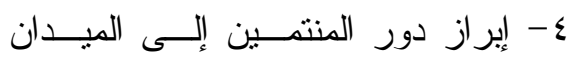

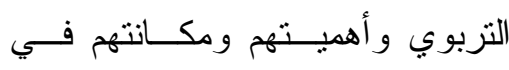
المجتمع.

ه- تطوير الممارسات التزبوية والإدارية و الارتقاء بمستوى الأداء. r - مفهوم التميز:

ومفهوم التميز من المفاهيم التي نالت اهتمام الباحثنين، ويمكن توضحيه من خــلدل

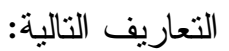

المعنى اللغوي للتميز فــي اللغـــة: عرف فـي المعجــم الوســيط علــى أنـــه "ميز القوم ساروا فــي خاصــية و انفــردو ا،

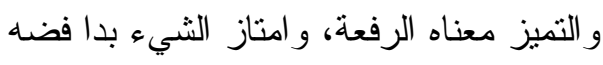

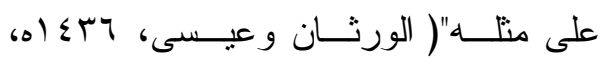
ص (79 (79) 
عدم الفشل أبداً، بل هناك إخفاقــات يحولهــا أ- عوامل التميز:

يعد التميز مطلباً وحاجة ضــرورية

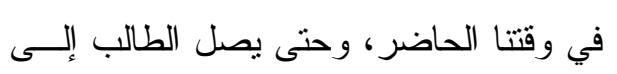

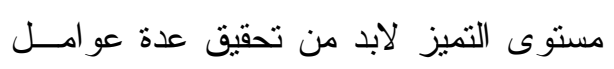
للنجاح.

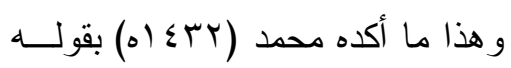

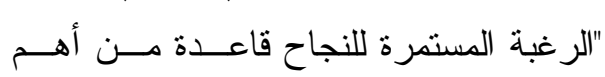

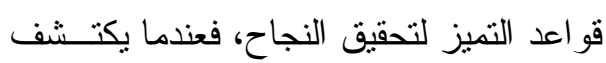

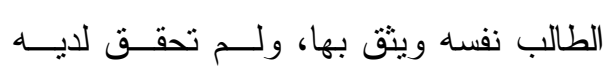

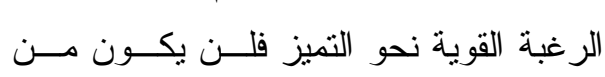

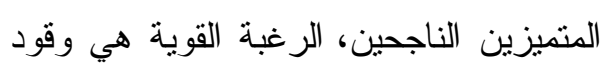

$$
\text { النجاح". (صسז). }
$$

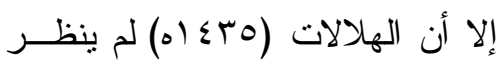

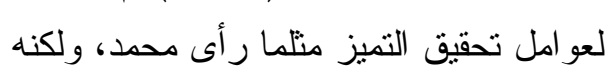

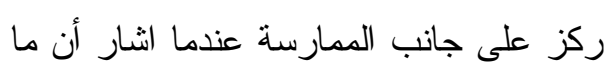
يسعى إليـــه الإنــسان باســتخدام إمكانياتـــه

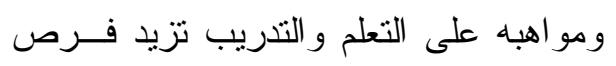

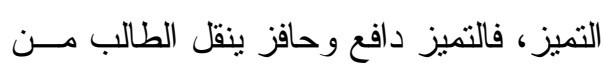

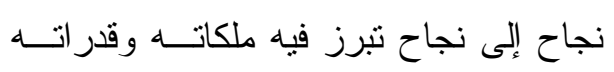

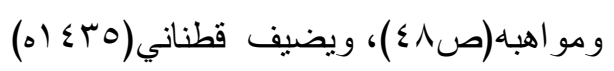
على ماذكره الهلالات في عو امل التمبز بأنها

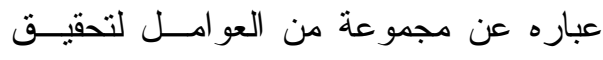

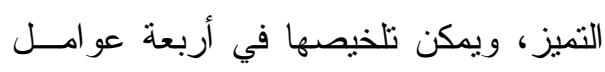
ومنها: الثقة بتحديد الهدف، والمرونة لأنهــا

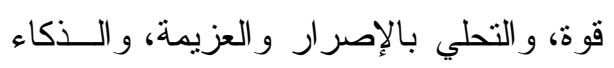

$$
\text { و التفكر بعمق.(صن ولنحي بالاصنر). }
$$

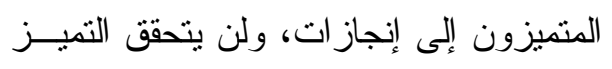

إلا من خلال الإدارة ذو الكفاءة العالية التـي لئي

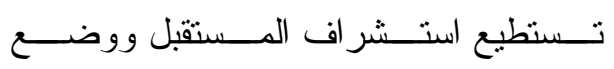

الاستر اتيجيات و البر امج و الخطط، لمو اجهـــة

التغير ات، وأن أي منظمة لا تـسعى للـتـعلم

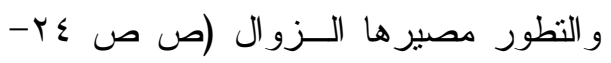

( T V

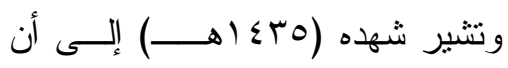

تحقيق التميز لدى الطلاب لن يأتي إلى مـن

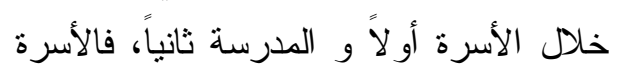
كما هو معروف تعد المؤسسة الاجتماعيــة

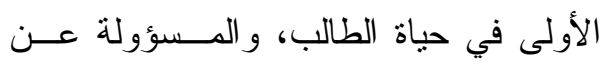
تتمية الابداع و الابتكار لديه بما يساعده على ولى

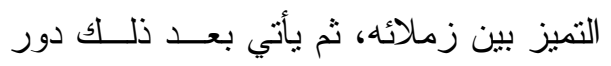

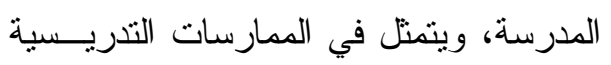

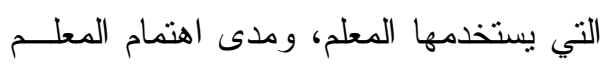

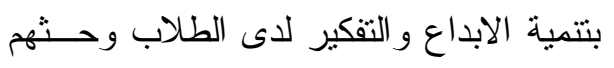
على التميز (صع ب).

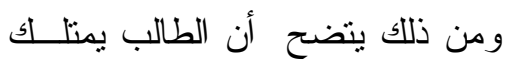

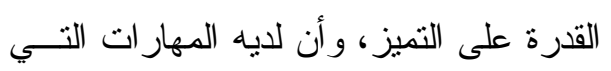
تميزه عن الآخرين، وتختلف اختلافاً إيجابيـاً

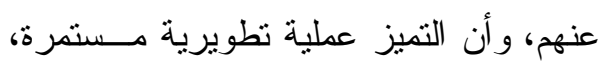
تحتاج إلى جهر ومواجهة لكل التحديز عمليه نطويربه التحديات التي

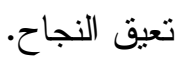


r- عوامل ذاتية شخصية: نتمثـل فـي

الاستعانة باله دوماً، و القابلية للتفكيــر

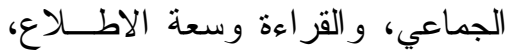

ووضوح الأهداف.

ب- عوامل تسريع: وتتمنل فــي تتظــيم

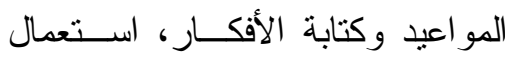

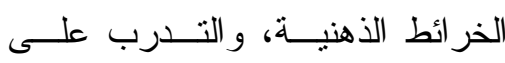

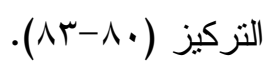

وتأتي أهمية العمل في الإسلام علـى

لسان النبي صلى الله عليه وسلم بقوله "إن الله

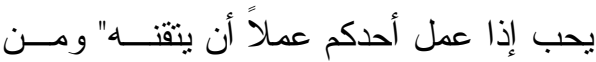
خلال ذلك يجب أن يكون العمل بر اعى فيــــ

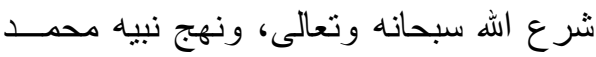

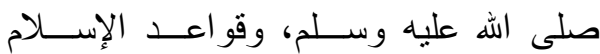

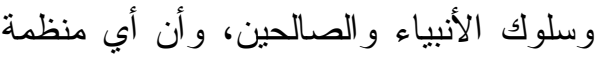
تسعى للعمل وفق إدارة متميزة لتحقيق قيمــة في سوق العمل لابد أن يتوفر لديها أمسـران

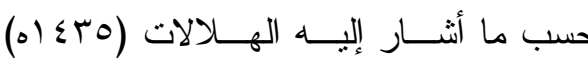
و وهما:

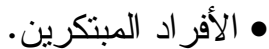

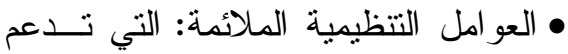
الابتكار و المبتكرين. ويمكن نوضيح أهمية عو امل التميـز من خلا الثكل رقم (r-1):
يعد التحفيز عامل اساسي للتميز فليس بوسع أي طالب القيام بأي عمل مــن غيـــر

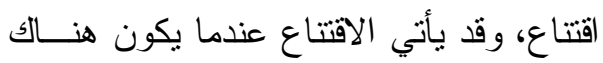

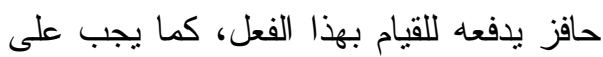

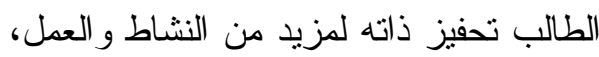
وأن لا يضخمها أو يحقرها و هذا ما أكده أبو

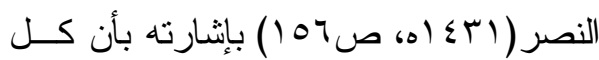

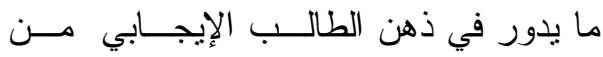

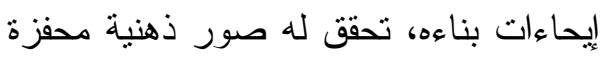
لذاته، ويساعد على اكتشافها وتتميتها. ووفقاً لهذا التعريف نجد أن كل طالب يمنلك من القدرة التي تجعله يستطيع تغييــر ما بذاته من برمجة سلبية إلى أخرى، تتمبز بالإيجابية وتحفيز ها. يؤدي ارتباط الحوافز بــالأداء إلـى

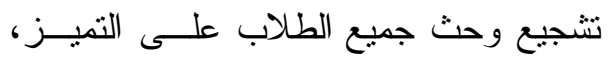
وربط الحوافز بالأداء المتميـز ضــــرورة؛ وهئ

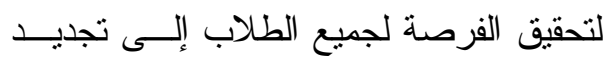

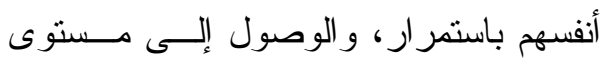
عالي من الإبداع في أعمالهم، وهذا ما يؤكده

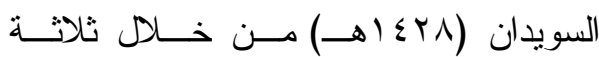
عو امل تساعد على تحفيز الإبداع: 1- عوامل بيئية داخلية: تتمنل في توفير

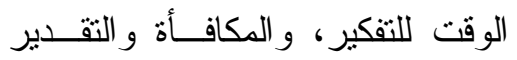

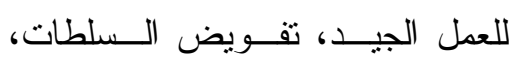
و الاتصال الجيد. 
الشكل رقم (r - 1 ) يوضح أهمية عوامل التميز (الهلالات، هب ؛ 1ه)

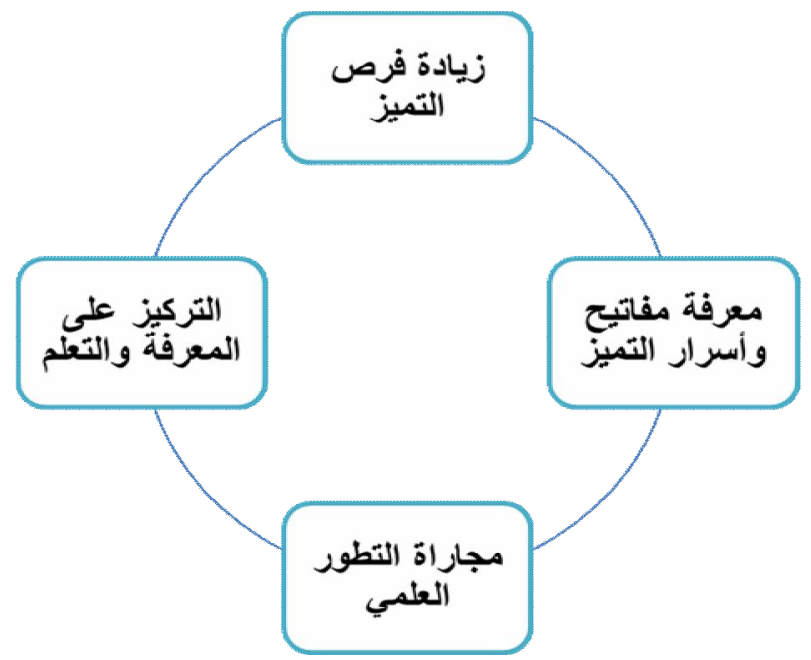

• المستوى التعبيري: ومحـور هــذا

المستوى هو التعبيــر المسـنقل فـي

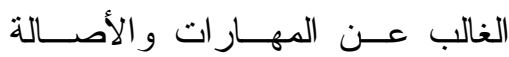

،ونوعية الإنتاج التـي تنكـون غيـر

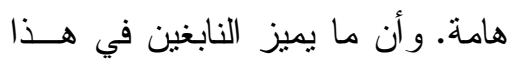

المستوى من الإبداع هو صفة التلقائية

$$
\text { وصفة الحرية. }
$$

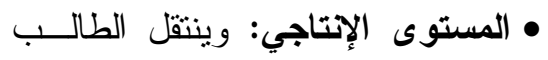

من المستوى التعبيري للإبـــداع إلـى لـى الإنى

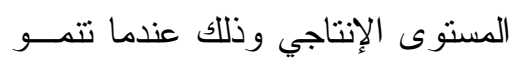

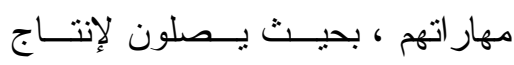

الأعمال الكاملـــة. ويكــــون الإنتـــاج

إبداعياً حينما يــصل الطالـب إلـى ولى الإنى
من خلال تتــاول مفهــوم التحفيـز

و أهمية عو امل التميز ، يتضح بأن المعرفة،

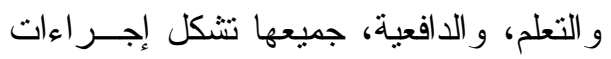

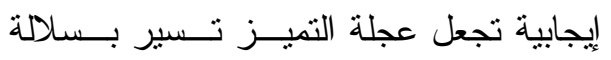

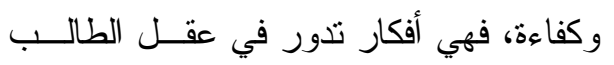

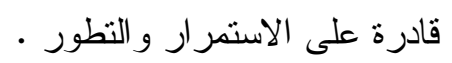

ب- مستويات التميز:

هناك مستويات متعددة للتميز وصل

إليها كالفن تايلور الذي قاد مؤتمرات جامعة

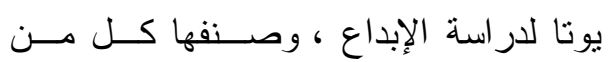

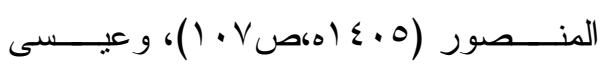

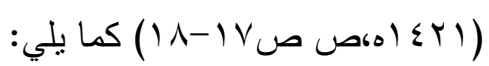




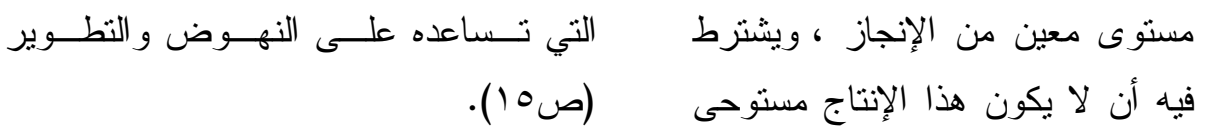

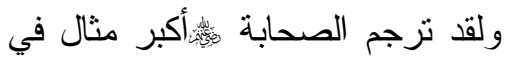

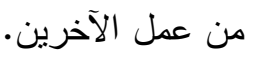

التتمية الذاتية، فعندما تغير عنـــدهم الكفــر

• المستوى الاختراعي: لا يتطلب هـــا

و الثرك إيماناً وتوحيداً ارتفع لديهم احتــرام

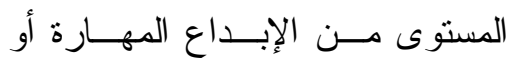

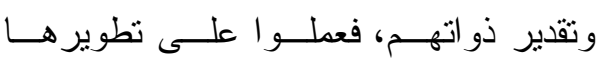

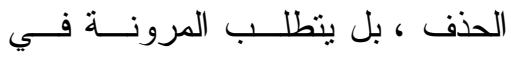

وتتميتها، إلى أن تبدلت عندهم القسوةُ رحمة،

إدرالك علاقات جديدة وغير مألوفـــة

و الجهل علماً، فارتقو ا بذلك إلى خيـــر أمســة

بين أجز اء منفصلة وموجودة من قبل.

أُخرجت للناس.

• المستوى البزوغـي: وفيــه بــصل

ومن ذلك يتضح أهمية تتميــة ذوات

الطالب إلى أعلى صورة من صــور

الطلاب وتحسينها وتطوير ها؛ لتحقيق الجودة

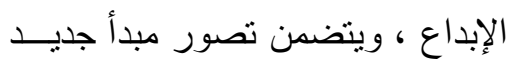

في المعرفة، و السلوك، و الفهم، و التو اصل مع وله

في أكثر المستويات و أعلاها تجريداً.

الآخرين، ولن يتحقق ذلـــــ إلا مــن خــله

ب- مفهوم التنمية الذاتية:

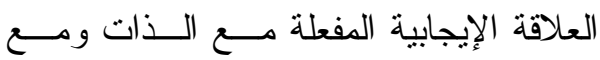

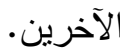

لقد سخر الله عز وجل قدرات لكـلـل

الطلاب، كل طالب لايه قــدرات بـستطيع

أ- خطوات تنمية الذات:

تغيير ما بذاته وتتميتها؛ لتحقيق ما هو أفضل

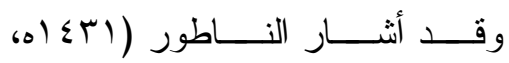

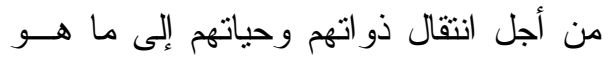

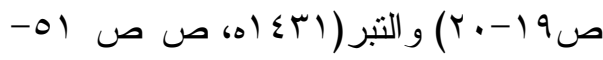

أفضل فيصنعو ا التنمية، ويـشير بــــادويلان

101) إلى مجمو عة من الخطو ات لتتمية الذات

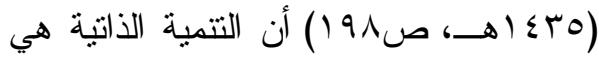
تتلخص في التالي:

"تحسين وتطوير وتفعيـلـل للــــات؛ لتحقيــق

1- اكتثاف حقيقة الـــات مــن خـلدل

$$
\text { الأهداف المرسومة". }
$$

التعرف على مو اضع القوة و الضعف.

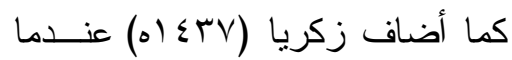

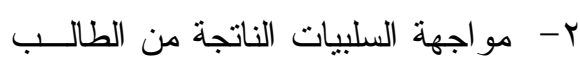

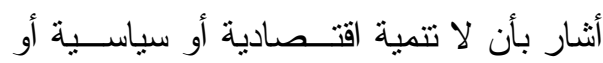

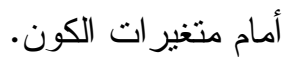

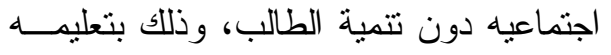

r- معرفة ما يمتلكه الطالب من مهار ات

وتتقيفه وتذريبه، على كل الفنون و المهار ات،

$$
\text { تحقق التقدم و النجاح. }
$$




\section{ع - مفهوم معرفة الذات:}

إن معرفة الذات هي مفتاح للتطـــور

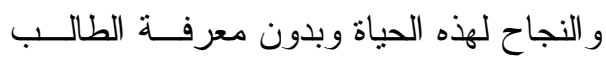

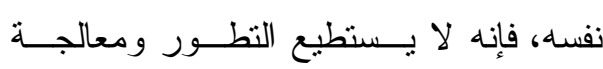
الضعف الني تمنع من أداء واجباته بـشكل

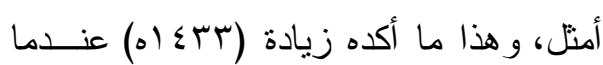

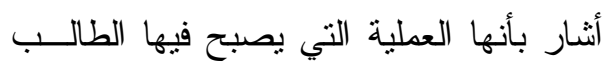

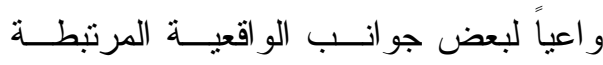

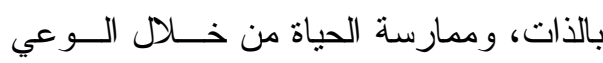

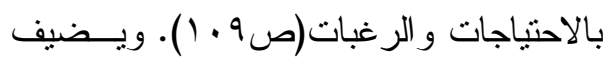

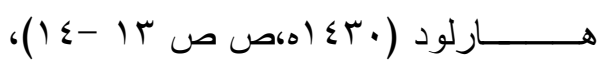

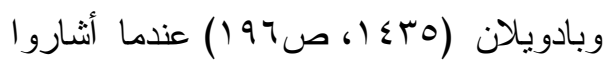

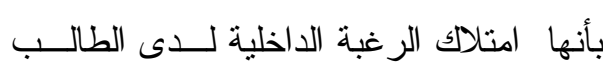
لاكتشاف ما يملكه، و اكتساب من الــصفات الجديدة ما يشاء، لكي يعيد بناء ذاته، ويصبح

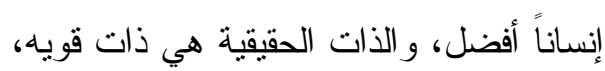
مثالية، وخالية من أي صفات شخصية غيــر

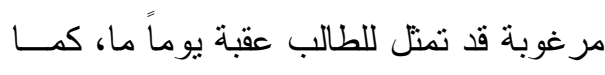
أنه خالية أيضاً من ثلاك الأفكار السلبية عـن فئن حقيقته.

إن معرفة الذات لدى الطالب تركــز

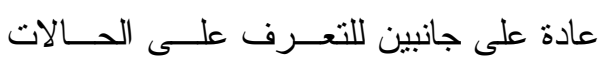
العقلية الخاصة به: الجانب الأول يتمنت فـي لئي

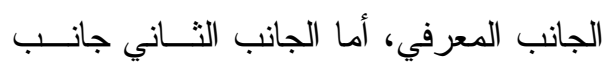

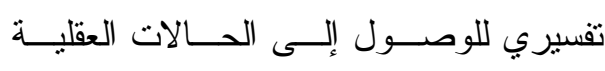

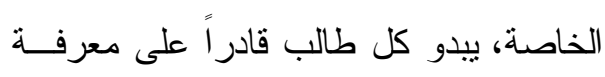
حالته العقلية الحالية، ولكن قد لا بستطيع فهم
ع - الحــوار الإيجــابي مـــع الآخــرين المتميزين. 0- البعد عن تأنيب الذات.

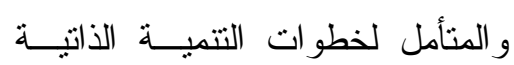

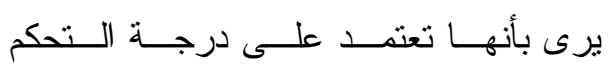

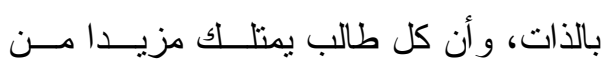
القدرات التي تمكنه من التطوير و النجاح في وني

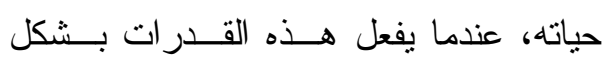
إيجابي. ب- العلاقة بــين جـائزة التعلـيم للتميـز والتنمية الذاتية: من خلال تتــاول مفهــوم الجـائزة

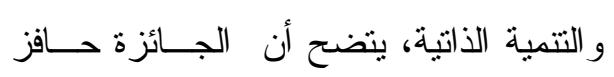

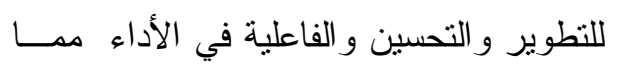

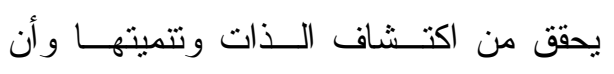

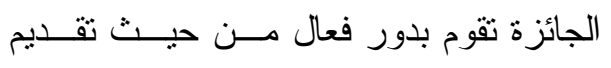

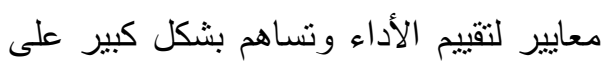
نشر نقافة التميز وتقود الطلاب نحو اكتساب مهارة جديده ،ووفقاً لمعايير جـائزة التعلــيم

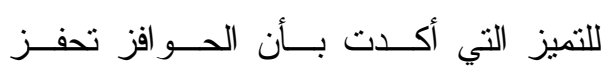

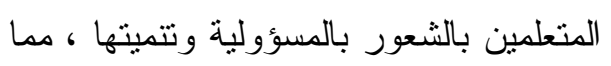

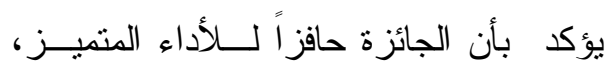

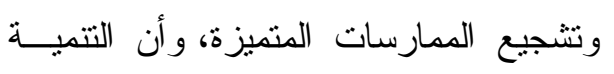
الذاتية ماهي إلا زيادة في التحسين و التطوير

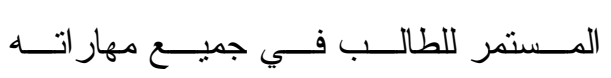
وقدر اته. 
الوعي المتز ايد بكيفية تعامل الطالب مع ميله

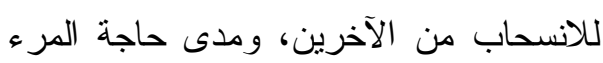
للمو افقــة، ودرجـــة الحاجــة إلـــى النظــــام

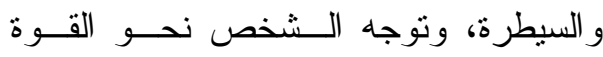
الشخصية و الاعتز اف بها كنقاط مهمة للتقييم الذاتي (Jensen،2010,pp.12:13). الثكل رقم (r-r

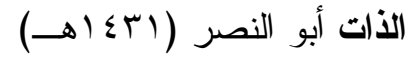

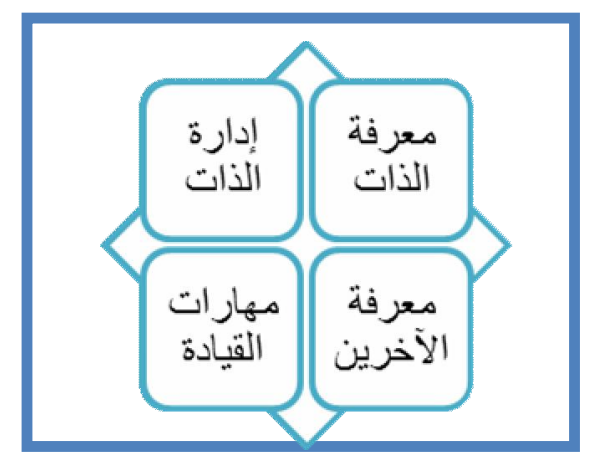

ب - العلاقة بين جـائزة التعلـيم للتميــز ومعرفة الذات:

من خلال تتاول مفهوم التميز ومفهوم

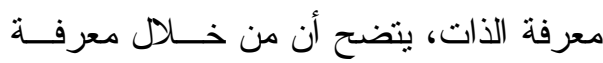

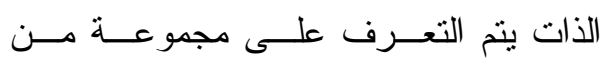
العناصر التي يمتلكها الطالب فمعرفة الــذات مجهوع

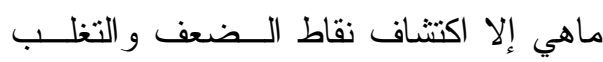
عليها، ونقاط القوة وتتميتها، وهذا ما يتضح

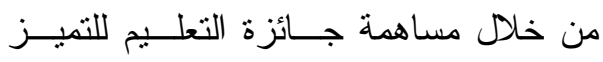
ودور ها المحفز في تحقيق الجانب الإيجابي لمعرفة الذات.

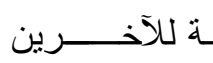
الحــــــالات العقليـ

.(Langland, 2015,p.227) كما تعرف على أنها "قدرة الطالــب

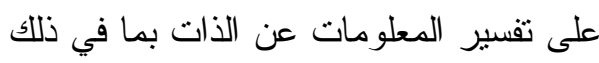
السلوك و الظروف، و التي يمكن ملاحظتهـــا

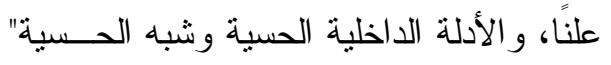
. (Knappik, 1435h, p184) ومن خلال ما أثنير إليه من المفاهيم

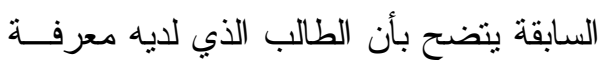

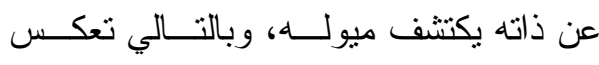

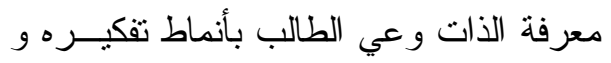
شعوره وسلوكه. أ- أهمية معرفة الذات:

إن معرفة الذات أهمية و اضحة تتمثل في أنها تساعد الطالب على اكتساب المعرفة

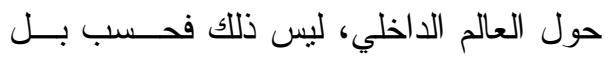

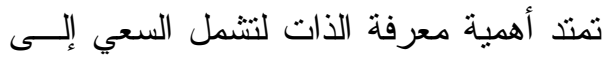
الوعي الذاتي وملاحظة التتاقضات بين القيم

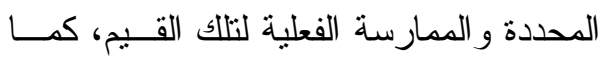
تؤثر معرفة الذات أيضًا على العلاقات بــين

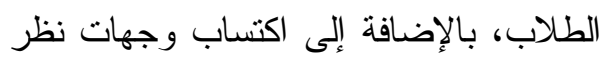

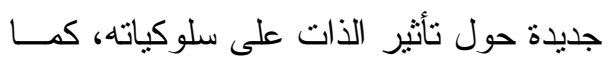
قد يمند الوعي إلى طبيعة وتأثير التفاعل بين الذات و الآخرين، فالقدرة علــى الحسـساسية

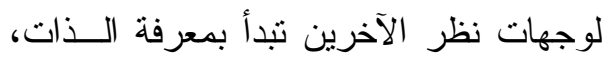

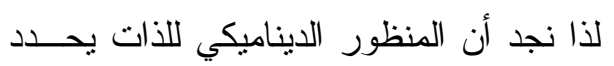


الطالب وذاته، من خلال الرغبة و العزيمــة

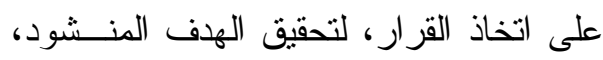
حيث كلما تأخر ، كلما بعد النجاح. أ - أهداف تطوير الذات:

يسعى دائماً الطالب لتحقيق الوصول

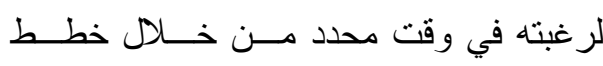

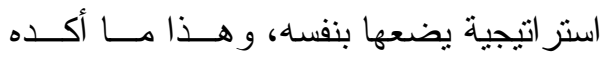
هيجان (9 (1) (0) عندما ركز على الجانسـب التدريبي في مجمو عة تتلخص فيما يلي:

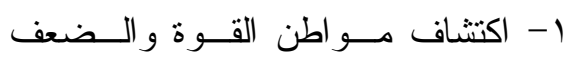
بنفسه. r- معرفة الكيفية التي يتدرب بها. r- التركيز على أساليب التدريب الحديثة بئة التي تتاسب الميول و الاهتمامات.

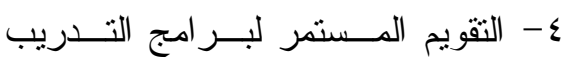

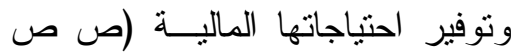
(roT-ror ب- أهمية تطوير الذات:

لتحقيق الوصول إلى حالـــة الرضــــا

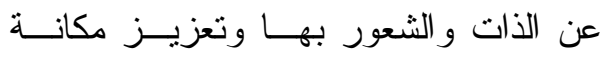
الطالب بين أقر انه، لابد من تطوير ها علــى لـى

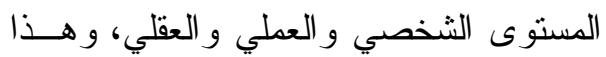

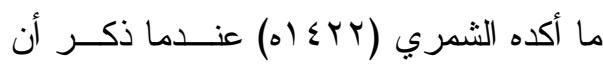
أهمية تطوير الذات تتطلق من خلال ارتباط حل المشكلات وابتكار طرق جديدة للعمـلـل فئل تسهم في زيادة الجودة، فتطوير الذات عملية

\section{0- مفهوم تطوير الذات:}

يسعى الطالب بصورة فطرية تحصيل

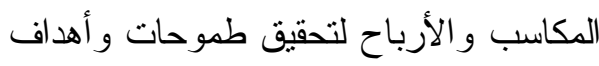

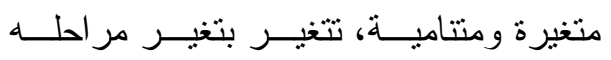

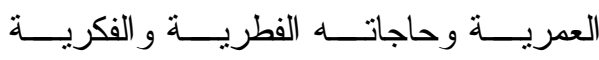

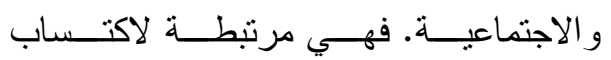

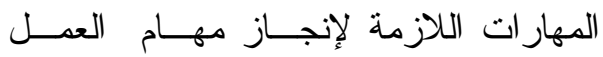
وتحسين الأداء.

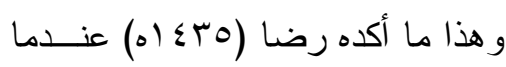

ذكر أن نطوير الذات له مـــلو لات كثيـــرة

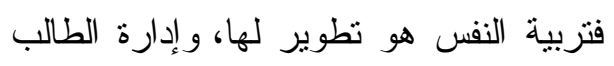

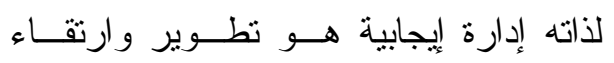
بالطالب، و لا يمكن أن يستقيم وضع الأســر

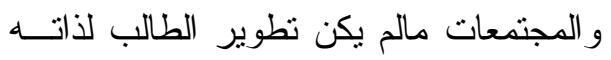
فعال ومستمر (ص (1) ) و (1).

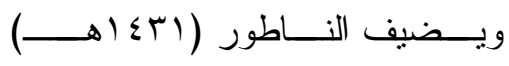
بطريقة أكثر شمولية بقوله "هو ذلك النــوع

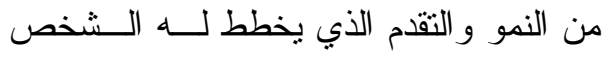

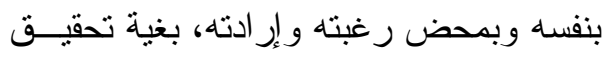

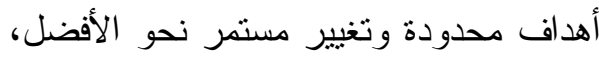

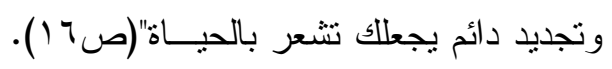
وتطوير الذات يتحقق من خلال المنهج الذي بادي بسعى إلى زيادة إمكانية ورغبة الطالب فـي مني

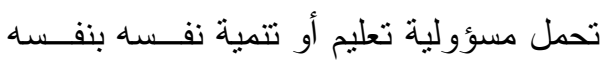
(peddler , 1988,p.2)

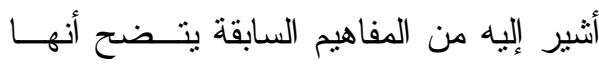

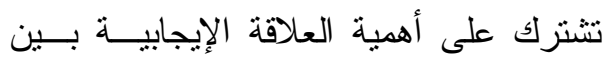




$$
\text { ع - التكيف مع الو اقع. }
$$

0- تحويل الإخفاق إلى نجاح.

$$
\text { 1- التحفيز للنفس(ص ص اسب-00). }
$$

وتتتوع مجالات تطوير الذات وتتعدد

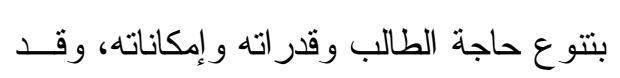

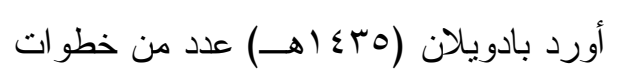

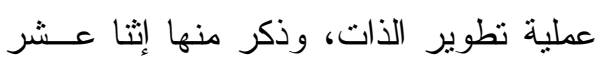

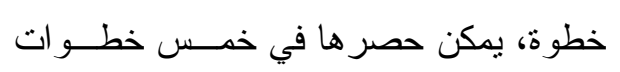

منها:

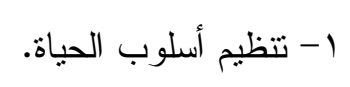

r- الاتصال الفعال مع الآخرين.

r- الثقة بالنفس.

$$
\text { ع - تحقيق التفوق. }
$$

0- و الجودة في العمل و الإنتاج و التخطيط

$$
\text { (ص ص (199-190-1). }
$$

ويضيف الباحث أن تطوير الذات مهر

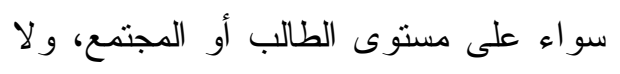

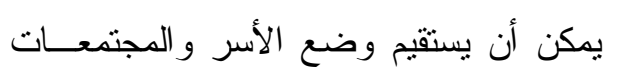

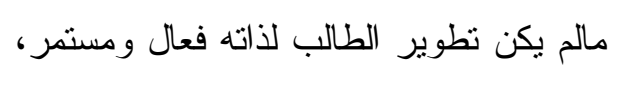

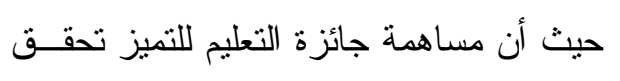

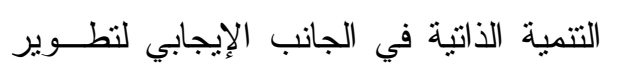

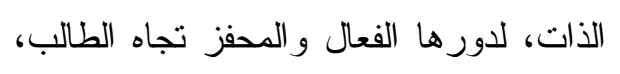
و لاثك أن الله سبحانه أودع في ذات الطالب مهار ات وقدرات يجعلها تساهم في تطــــير

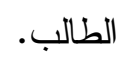

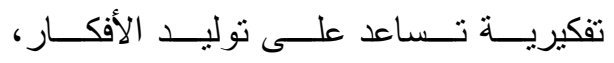

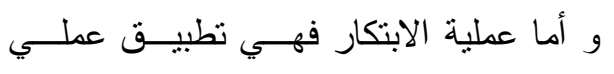
لهذه الافكار ؛ لتحقيق أهداف المنظمة بطريقة

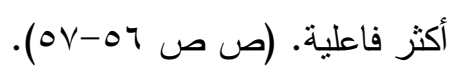

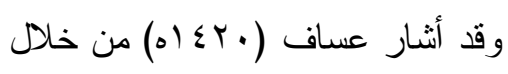
أهمية تطوير الذات للطلاب تتمنل من خلال

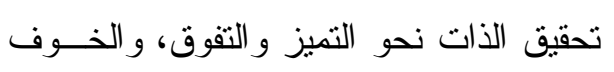

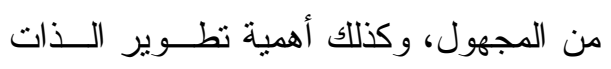
للجماعات و المنظمات تتمنل من خلال نوفير مقومات تطوير الذات للعاملين فيها كوســيلة

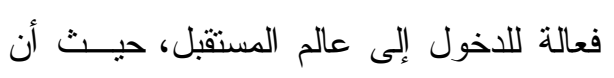
تجاهل ذلك المطلب من شأنه أن يؤدي إلـى على إلى التعجيل بانهيار المنظمة (ص.بr). ج- مراحل تطوير الذات: من الضروري أن نتعرف على طرق

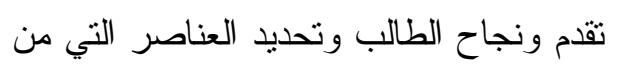

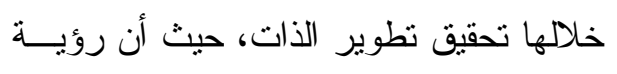
الطالب لتطوير ذاته من أحد العوامل المؤثرة في الأداء و التقوق.

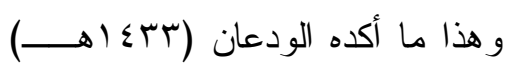

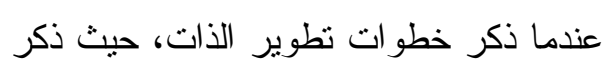
منها عشرون قاعدة، ويمكن حـصر هـا فــي

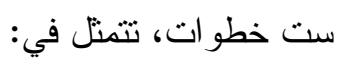
1- تحديد الأهداف. r- استثمار الوقت. r- التخطيط للمستقبل. 
أما المهنة فتعني مجموعـــة مــن الأعمــال المتشابهة التي تتنمي إلى عائلة مهنية و احدة بحيث يستطيع الطالب الذي مارس إحداها أن

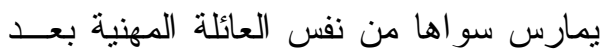
تدريب طفيف لتو اجد المعرفية التي نربط بين

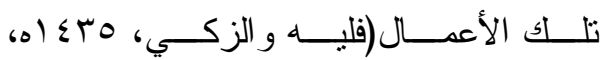
(ona, 2015, ص (ז). ويتقق كل من آونا

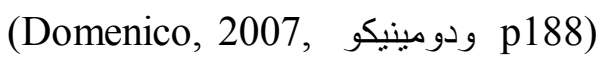
على أن الدو افع، و الطموحات الداخلية و القيم و الأهداف الثخصية لتوجيه السلوك الفــردي لـوني لكل طالب نحو تحقيق المهنـــة المطلوبـــة. ترجمة بو اسطة الباحث.

ومن خلال ما أثنير إليه من المفاهيم

السابقة بتضح أن التطلعات المهنية تعد بمثابة

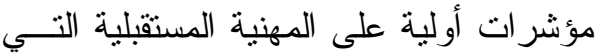
يرغب الطالب في العمل بها، ومن ثم يسعى

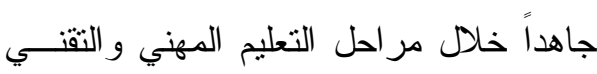
للوصول إليها، هذا وتلعب التطلعات المهنية

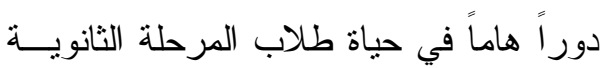

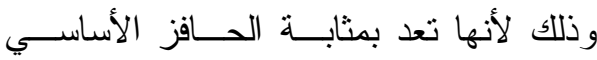

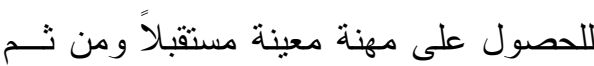
تزيد من اهنمام الطالب بمسستوى تحـصيله

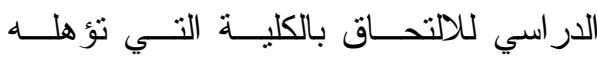
للحصول على المهنة التي يرغب فيها. أ - أهداف التطلعات المهنية:

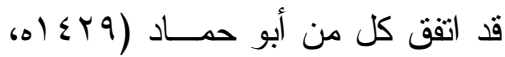

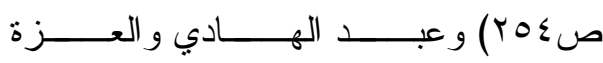

د - العلاقة بين جائزة التعليم للتميز وتطوير

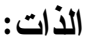

من خلال تتاول مفهوم التمبز ومفهوم

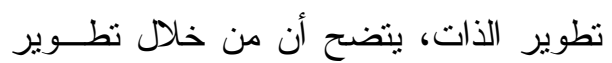

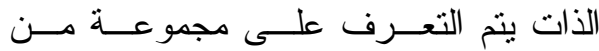
الخطو ات التي تحدد نجاح وتحـسين الـــات لدى الطالب، منها استثمار للوقت ، وتخطبط

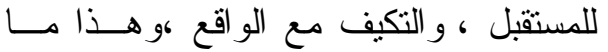
يتضح من خلال مساهمة جائزة التعليم للتميز ودور ها المحفز في تحقيق الجانب الإيجابي لتطوير الذات. 4- مفهوم التطلعات المهنية: التطلعات المهنية قد تكون مثاليــة أو و اقعية، فالتطلعات المهنية المثالية هي المهن التي يرغب الطالب في الحصول عليها إذا لم تكن هنالك قيود على الفــرص أو المـــوارد

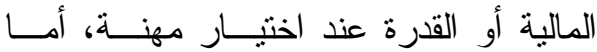
التطلعات الواقعية فتتير إلى المهـن التـي

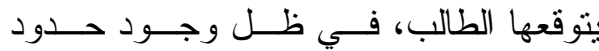

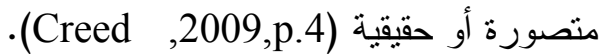

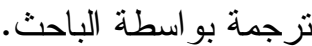
إن مصطلح التطلع المهني يتكون من مكونين هما التطلع و الذي يعرف على أنــهـ

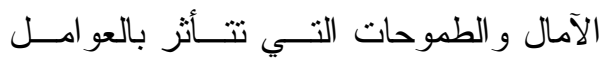
الذاتية و الثخصية Das and Bhagabati)

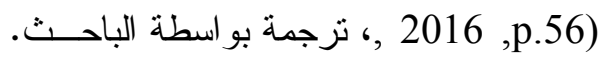


1 - تلبية حاجات الطالب: ليكون قادر اً على

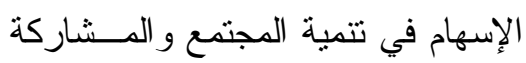

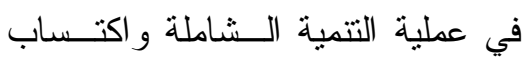

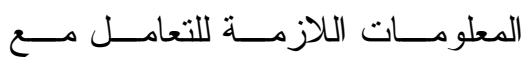

مستحدثات تكنولوجيا التعليح.

r- تلبية لحاجات المجتمع: وذلــك مــن

خلال مواجهة مطالب النمو الاقتصادي ودي

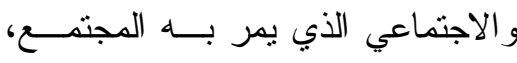

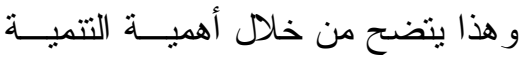

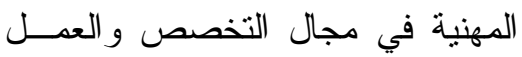

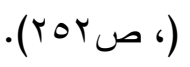

وفي ضوء ما سبق نتـضـح أهميــة

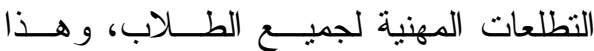

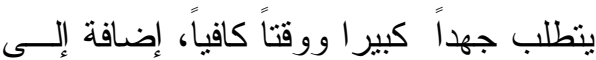
مساعدة الطالب المستمرة في تعلم الــسلوك

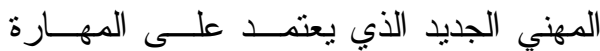
و الخبرة المهنية المنطورة.

ج- العوامل التي تــؤثر علــى التطلعـات

المهنية:

إن الطالب و هو يتوجه إلــى اختيــار

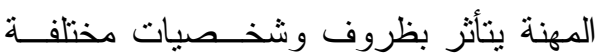
تلعب دورها في تحديد اختبار اتـهـه ويـشير

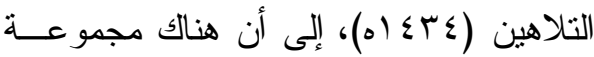

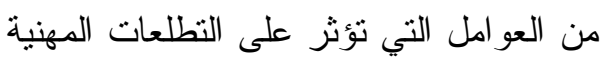
لدى الطالب ؛ تتمثل تلاك العو امل فيما يلي: ا ـ القدرات العقلية للطالب.

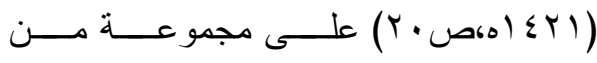

الأهداف التي تحــدد دور الطالــب بكفــــاءة وفاعلية يمكن تلخيصها من خلال الآتي: 1- مساعدة الطالب على فهم نفسه وتقويم ذاته.

ץ- مساعدة الطالب و إعداده علــى اتخــاذ

القرارات السليمة المتعلقـــة بمـستقبله

$$
\text { الأكاديمي أو المهني. }
$$

ب- تشجيع الطالب على تتميــة اتجاهـــات وقيم إيجابية نحو المهن المختلفة.

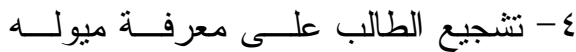

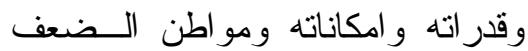
و القوة لديه.

0- مساعدة الطالب في التخطيط الدر اسـي ولي<smiles>C1=C[As][As]1</smiles>

צ- نزوود الطالب بمعلومات عـن المهـن

وعن الحاجة لها في البيئة المحلية.

و هذه الأهــــــ الإيجابيــة للطــلاب

تستلزم من الأسرة و المجتمع و القائمين علــى الإهى

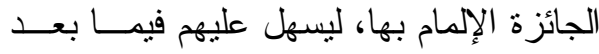
حسن التعامل مع هذه الميول و الــــات مــن حيث اكتشافها ور عايتها. ب- أهمية التطلعات المهنية: تبرز أهمية التطلعات المهنيــة فــي جانبين أساسيين من جو انب النظام التعليمـي لهي كما أثنار إليها أبو حماد (9 جـ (ه) و هما: 
ع- الميل الحصري: من خلال الاســنبانة

بحيث يكون لكل سؤال درجة معينــة

$$
\text { تقيس ميوله. }
$$

تتكل الميول سمة هامة من سـمات

الثخصية(التي اهتمت بها الدر اسات النفسية)

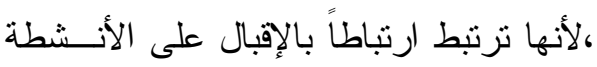

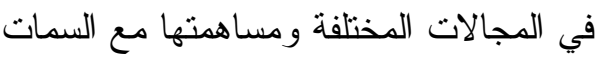

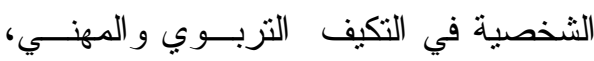
وأن الميول تحدد ما بفعله الطالب أكثر مـنـ أن تحدد الكيفية التي يتم بها العمل. إن الميل شعور عند الطالب يجعله بصورة مسستمرة نحو الاهتمام بموضوع معـين (عبــدالهادي

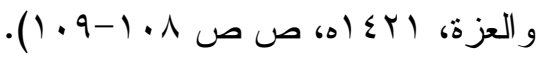
كما يرى الباحث من خلال اطلاعــه

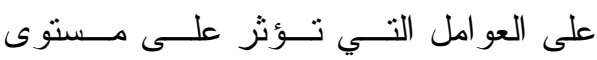

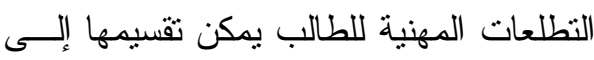
عو امل تتعلق بالطالب نفسه وعو امل محيطة بالطالب. فالعو امل التي تتعلق بالطالب نفسه

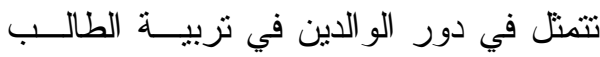

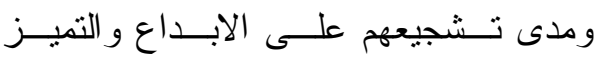

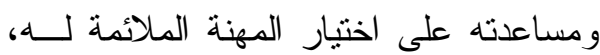

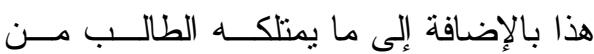

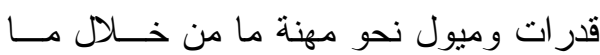
يمارسه ويكتسبه في حياته اليوميــة ومــدى استعداده للوصول إليها و العمل بها، وما يمر

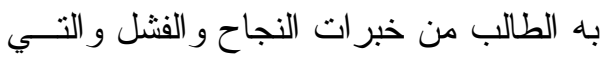

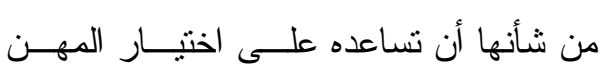

r. قدر ات الطالب الخاصة و التـي مـن

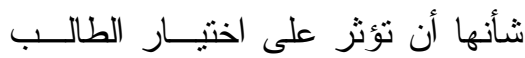

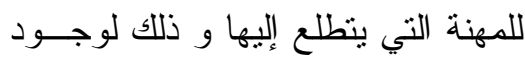
بعض المهن التي تتطلب قدرات خاصة

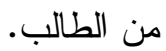

r. شخصية الطالب ؛ حيث تؤثز شخصية الفرد على اختيار للمهنة و ذلك لوجود بعض الثخصيات التي تتلاءم مع تلك المهن.

ع. الو اقعية: تؤثز العوامل الواقعية علــى

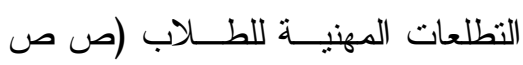

$$
\text { . }
$$

๑. ميول الطالب نحو المهن؛ حيث يرغب

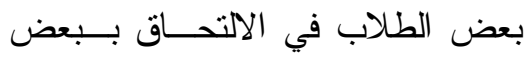

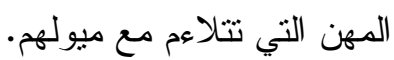

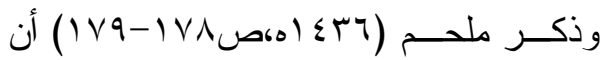
هناك أربعة أنو اع من الميول منها:

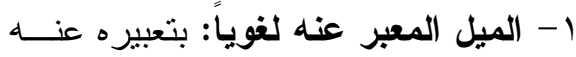

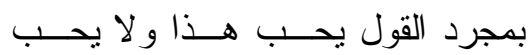
ذالك.

r- الميل الظاهر: عن طريــق الأنـشطة

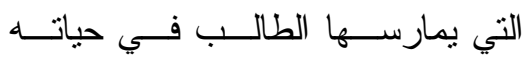

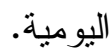

r- الميــل مـــن خـــلال الاختبـــــارات الموضوعية: الطلاب الذي لديه ميـلـل في أي مجال لديه معلومات و افيه عنه. 
وقد هدفت الدراسة إلى التعرف إلـى معرفة مدى تطبيق معلمي العلــوم لمعــايير

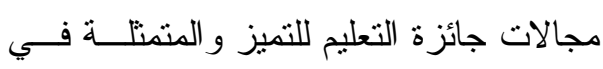
(مجال التمكن العلمـي، ومجــال تخطــيط

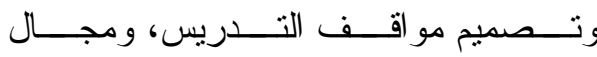
استر اتيجيات التدريس)، وقد استخدم الباحث أداتين لتحقيق أهداف الدر اسة و هما: بطاقــة

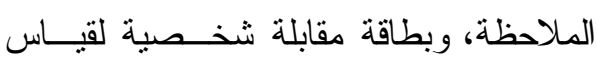
جــودة الأداء التذربــسـي لمعلمــي العلـــوم بالمرحلة الثانوية وفقاً لمعايير جائزة التعلــيم للتميز ، وقد اســتخدمت الدر اســـة المــــهج الوصفي (المسحي و التحليلي).لقد توصــلت هذه الار اسة إلى مجموعة من النتائج ومنها تحقيق إحدى معايير جائزة التعليم للتميز التي تتاسب الدر اسة الحالية معيار (إثارة دافعيــة المتعلمين وتفكير هم) وكان من أبرز النتائج ما بركز على جانب تعزيز الاتجاه الإيجــابي نحو مادة التخصص، وتحفيز المتعلمين على التفاعل الإيجابي فـي الموقــف التذريـسي، وتحديد الخبر ات السابقة للمتعلمـين، وربــــ المقرر ومفرداته بواقع المتعلمين وبيئـتنهم، وتتمية الثعور بالمسؤولية لدى المتعلمين.

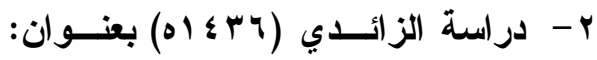
"مدى إسهام جائزة وزارة التربيــة والتعليم للتمبـز فـي تحسـين الأداء الإداري لمديري المدارس في محافظة
الملائمة له، بالإضافة إلى مفهوم الطالب عن

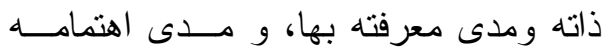
بتطوير ها كل ذلك من شأنه أن يؤثز علـى ولى التطلعات المهنية، أمـا العوامــلـ الخارجيـــة فتتمثل في ثقافة المجتمع المحيطة بالطالــب،

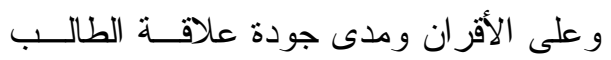
وتفاعله مع الآخرين، بالإضافة إلى متطلبات المجتمع كل ذلك أيضنا بساهم فـي تـشكيل التطلعات المهنية لدى الطالب. د- العلاقة بـين جــائزة التعلــيم للتميـز والتطلعات المهنية: من خلال تتاول مفهوم التمبز ومفهوم التطلعات المهنية، يتـــح أن مــن خــلال التطلعات المهنية يتم التعرف علــى الآمــال و الطموحات المستقبلية التي تتمــي الميــول المهنية لدى الطالب، و هذا ما يتـــح مــن خلال مساهمة جائزة التعليم للتميز ودورهـــا

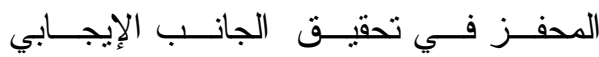
للتطلعات المهنية. ثانياً : الدراسات السابقة: أ - الدر اسات التي تناولت الحوافز وجائزة التعليم للتمبز :

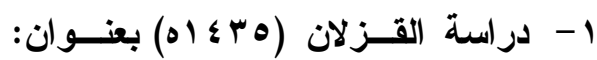
"مدى تحقيق معلمي العلوم بالمرحلــة الثانوية في مدينة الرس لجودة الأداء التدريسي وفقاً لمعاييز جائزة التربية 
ب - الدراسات التي تناولت معرفة الاتات:

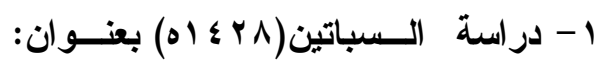

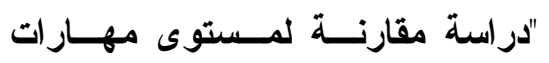

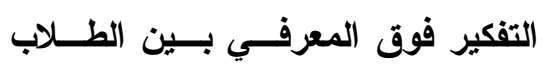
الموهوبين وأقرانهم العاديين بالمرحلة المتوسطة في مدارس مكة المكرمة". هدفت الدراسة إلى استقصاء الفروق مدأ مكه لمكرمه في مسنوى مهار ات التفكير فوق المعرفـي البي لهني

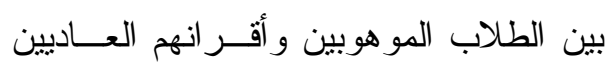

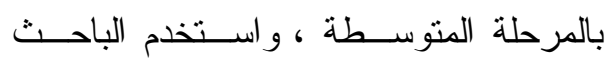
المــنهج الوصـــي الإرتبـــاطي، و اســـتخدم الاختبار أداة لجمع المعلومات. وكان من أهم الإرهم

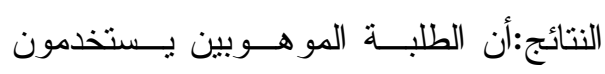

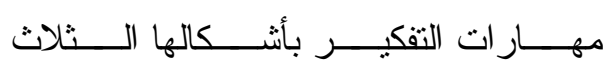

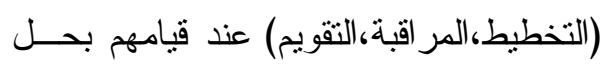

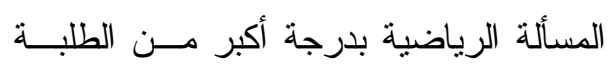

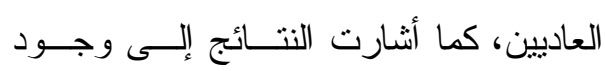
فروف على مستوى الصف الدراســي فــي وني استخدام مهار ات التفكير فوق المعرفي تزداد

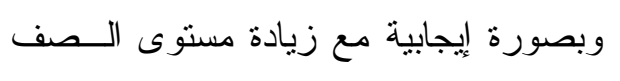
الدر اسي للطلبة .

ج- الاراسات التي تناولت تطوير الأت:

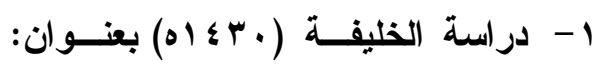

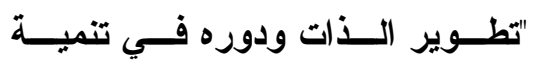
المهارات الأمنية":

هدفت الدراسة فـي التعــرف عالـى لـى

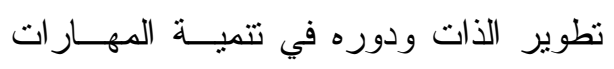

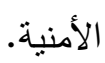

هدفت الدراسة إلى التعـرف علـى درجة تحقق معايير جائزة التعليم للتميز فـي لئي

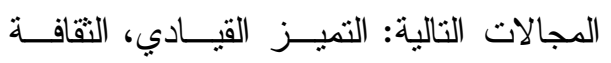
المؤسسية، الجودة، التتمية المؤسسية، إضافة إلى التعرف على درجة إسهام جائزة التعلــيم

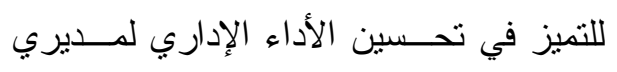
المدارس من وجهة نظر هم. وقد تم اســتخدام المــنهج الوصــفي المسحي، وقد نم استخدام الاسـتنبانة كــأداة للار اسة.

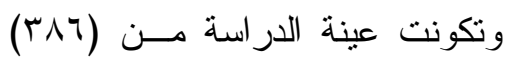

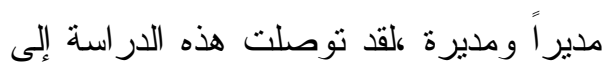

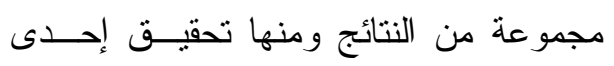

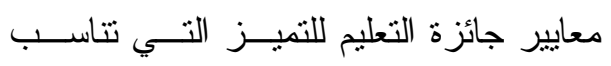

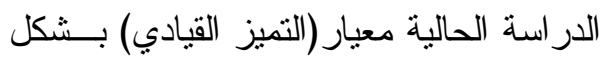
كبير جداً، من قبل مديري المدارس وكــان من أبرز النتائج ما يركز على جانب التشجيع

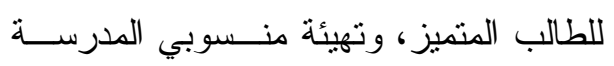
على التغيير ، وكذللك تحقيق معيــار (التقافـــة المؤسسية) بدرجة ممارسة بشكل كبير جـــاً من قبل مديري المدرسة، وكان مــن أبــرز

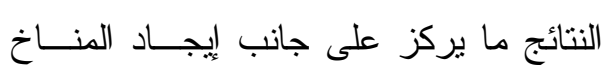

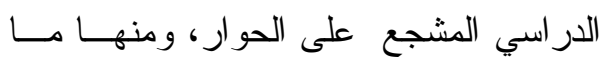

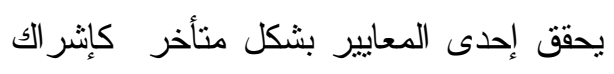

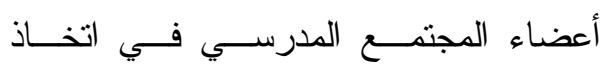

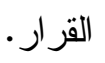


اختيار تخصصاتهم المهنية المختلفــة التــي تتاسب قدر اتهم، وقد تكونت عينة الدراســـة من طلاب كلية بارك في المملكة المتحـــدة،

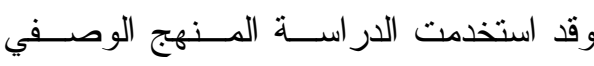
المسحي.

واستخدمت المقابلة أداة للار اسة. لقد

توصلت هذه الدراسة إلى مجموعــة مسـن النتائج ومنها أهمية نوجيه الطلاب و إرشادهم إلى التخصصات المهنية التي تتاسب قدر اتهم

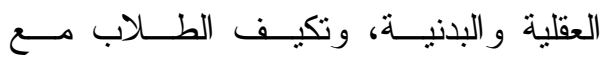

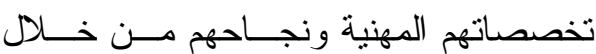
التوجيه من قبل المختصين بالإرشاد المهني. ترجمة بو اسطة الباحث. أوجه الاستفادة من الاراسات السابقة: اســـتفادت الدر اســـة الحاليـــة مـــن الدر اسات السابقة في الوقوف على الكتــبـ و

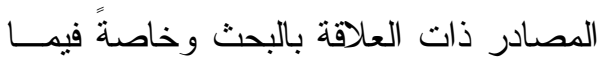

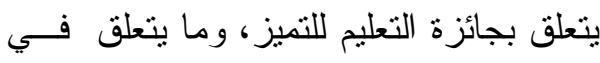
مجال تتمية الميول المهنية، وتطوير الذات. و استفادة الدر اسة الحاليــة مــن الدراســات

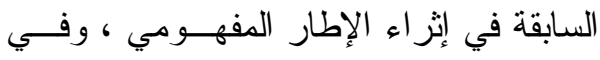

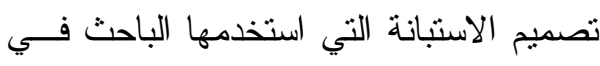

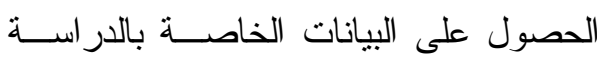

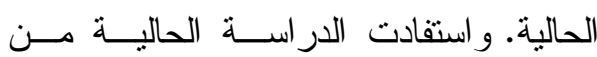
الدراسات السابقة في اختيار المنهج المناسب للار اسة، و الأسلوب العلمي في البحث مسنـ حيث تسلسل الأفكار وتتظيمها.
وقــــــــتخدمت الدر اســـة المــنهج

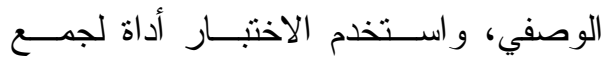

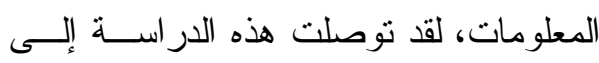

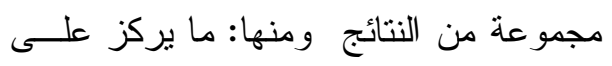

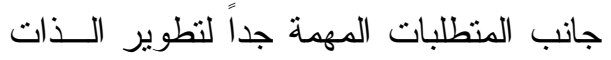

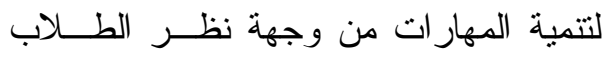
و المعلمين من خلال تهيئة المتدربين نفـسياً

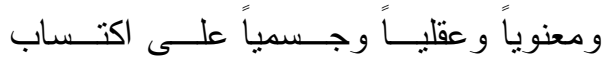
المهار ات الملائمة لطبيعة العمل ، وتـــوفير

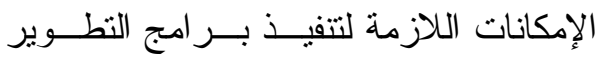
الذاتي ،ومساندة القيادة العليا لبر امج التطوير

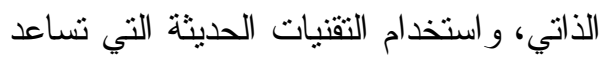
على سرعة إعــداد المتــدربين لاكتــساب

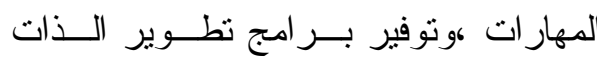

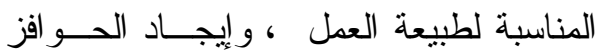

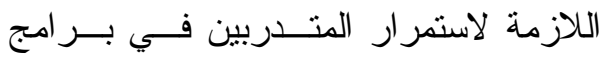
تطوير الذات، وقلة الكو ادر البشرية المؤهلة لتطبيق برامج تطوير الذات ،وقلة البــر امج لئه

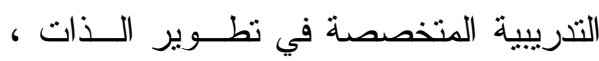
و عدم تو افر الحو افز المادية التي تشجع على التحاق منسوبي العمل ببر امج تطوير الذات. د - الدراسات التي تناولت التطلعات المهنية:

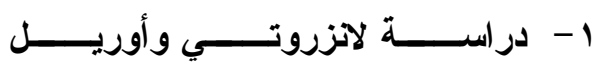
(Lanzerotti \& orr e] 11،2006) بعنوان: "الإرشاد والتطوير المهني": هدفت الدر اسة إلى الكثف عـن دور الإرشاد المهني في دعم وتوجيه الطلاب في 
مجتمع البحث، ويقصد بمجتمع البحث فـي البحث العلمي بأنه "ما تعدـــم عليـــه نتــائج

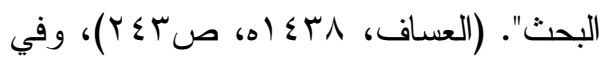
ضو ء ذلك حُدَ مجتمع البحث بجميع معلمي المرحلة الثانوية بمحافظتي حوطة بني تمــيم

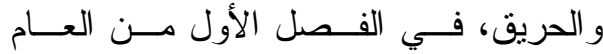

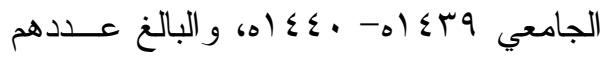

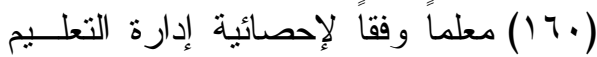

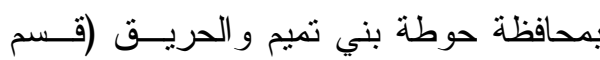

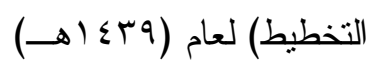
-

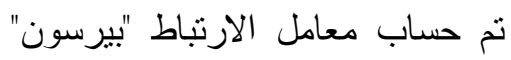

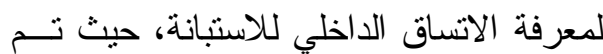
حساب معامل الارنباط بين درجة كل عبارة من عبار ات الاستبانة بالدرجة الكلية للمحور الذي تتنمي إليه العبارة كما يلي:

\section{الفصل الثالث :منهجية البحث وإجرائاتها} ا - منهج البحث:

بما أن هذا البحث يستهدف استطلاع

وجهات النظر حول الكثف عن إسهام جائزة

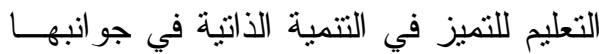

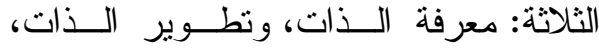

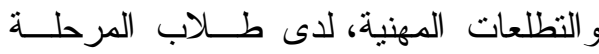

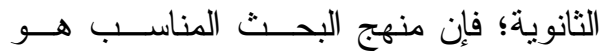
الوصفي في نمطه (المسحي)، والذي يعرفه

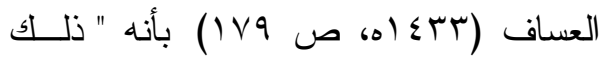
النوع من البحث الذي يتم بو اسطته استجو اب إناب

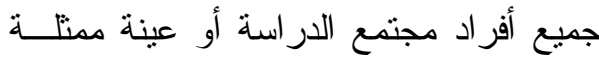
منهم، وذلك بقصد وصف الظاهرة المدروسة الته من حيث طبيعتها أو درجة وجودها ". وهن

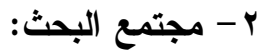

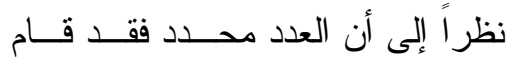

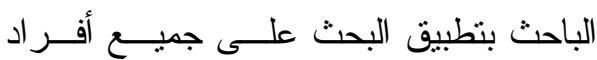
جدول (r-r) معامل (ارتباط بيرسون) لكل عبارة من عبارات محاور الاستبانة

\begin{tabular}{|c|c|c|c|c|c|c|c|}
\hline \multicolumn{2}{|c|}{ المحاور الثلاثة } & \multicolumn{2}{|c|}{ المحور الثالث } & \multicolumn{2}{|c|}{ المحور الثاتي } & \multicolumn{2}{|c|}{ المحور الأول } \\
\hline معامل الارتباط & العبارة & معامل الارتباط & العبارة & معامل الارتباط & العبارة & معامل الارتباط & العبارة \\
\hline$* *, \mathrm{~V} \circ \mathrm{V}$ & 1 & $* *, \vee \neg \wedge$ & 1 & $* *, \leqslant \circ V$ & 1 & $* *, 77 \mathrm{~V}$ & 1 \\
\hline$* *, 790$ & r & $* *, \wedge,$. & $r$ & $* *, 0 V Y$ & r & **, & r \\
\hline **. • T & $\mu$ & $* *, \vee \curlyvee \curlyvee \wedge$ & $r$ & $* * ., 0 \vee q$ & $r$ & $* *, \leqslant \wedge q$ & $\mu$ \\
\hline$* *, \wedge \vee V$ & $\varepsilon$ & $* *, 79 \leq$ & $\varepsilon$ & $* *, \vee, q$ & $\varepsilon$ & $* *, 0 \ldots$ & $\varepsilon$ \\
\hline- & - & $* *, 790$ & 0 & $* *, T \vee V$ & 0 & * * OY T & 0 \\
\hline - & - & $* *$, vor & 7 & $* *, \vee \wedge$. & 9 & $* *$, or. & 7 \\
\hline- & - & $* *, 0 \leqslant 7$ & V & $* *, \vee>9$ & V & **,or. & V \\
\hline- & - & $* 0,0 \wedge 9$ & $\wedge$ & $* *, \vee q$. & $\wedge$ & $* *, \vee \vee 99$ & $\wedge$ \\
\hline- & - & - & - & $* *, \vee \vee$. & 9 & $* *, 0 \vee 7$ & 9 \\
\hline - & - & - & - & & 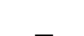 & - & - \\
\hline - & - & - & - & & 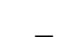 & - & - \\
\hline
\end{tabular}


بأنه يفيد في ترنيب المحاور حسب أعلى متو سط حسابي.

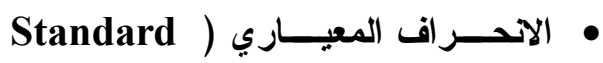

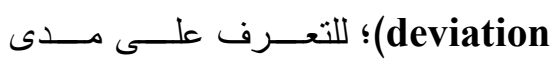
انحر اف استجابات أفر اد عينة البحث لكل عبارة من عبار ات متغيـر ات البحــث،

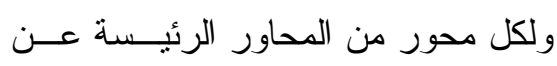

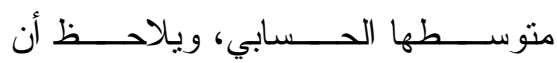
الانحر اف المعياري يوضح النشتت فـي استجابات أفراد عينة البحث لكل عبـارة من عبارات متغيرات البحث، إلى جانب المحاور الرئيسة، فكلما اقتربت قيمته من لفي

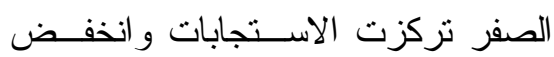
تشتتها بين المقياس.

الفصل الرابع:عرض نتائج البحث ومناقشتها إجابة السؤال الأول: ما إسهام جائزة التعليم للتميّز في تتمية (معرفة الذات) لدى طــلاب الابه المرحلة الثانوية؟ percentages الخصائص الثخصية والوظيفية لأفــر اد عينة البحث، وتحديد اســتجاباتهم تجــاه عبار ات المحاور الرئيسية التي تتضمنها

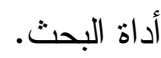
• المتوسط الحسابي الموزون (المـرجح) "Weighted Mean" مدى ارتفــاع أو انخفــاض اســتجابات

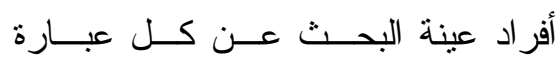
من عبار ات متغير ات البحث الأساســـة،

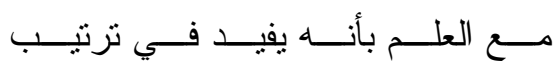
العبار ات حسب أعلى منوســ حس حسـابي

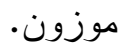
• المتوسط الحسابي (Mean)؛ للتعـرف

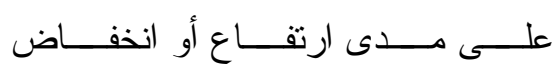

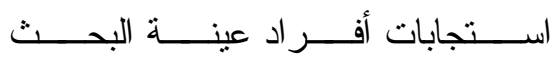

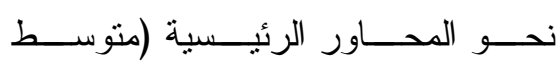

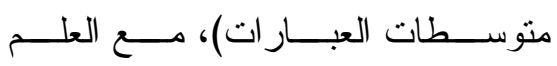


جدول (ع - 1) يوضح المتوسطات الحسابية والآحراف المعياري لترتيب عبارات المحور الأول

\begin{tabular}{|c|c|c|c|c|c|}
\hline اللفظية & الالاحرافي & المتوسط & الرتبة & 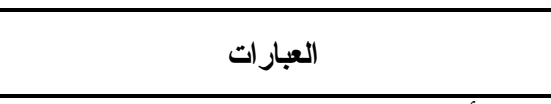 & p \\
\hline مهر جدا &., 914 & $\varepsilon, \leqslant 1$ & 1 & تبرز أهمية الطالب بين زملائه & $\varepsilon$ \\
\hline مهر جدا & $\cdot, \mathrm{AVT}$ & $\varepsilon, r_{0}$ & $\bar{r}$ & تتنمى الثعور بالثقة في النفس لدى الطلاب. & 1 \\
\hline مهر جدا & $\cdot, \wedge \vee$ & $\overline{\varepsilon, Y \mu}$ & $\bar{r}$ & تسهر فى المحافظة على الانجاز ات لدى الطلاب. & 0 \\
\hline מهi & $\cdot, \wedge .7$ & $\$, 19$ & $\varepsilon$ & تشهر في تعزيز نقاط القوة لدى الطلاب. & $\frac{r}{r}$ \\
\hline مهر & $\cdot, \Lambda \vee r$ & $\varepsilon, 1$ & $\circ$ & تسهر في اكتناف الأفكار للدى الطلاب & $\mathrm{v}$ \\
\hline مهر & $\cdot, 9 \vee \mathrm{Y}$ & $\varepsilon,+\wedge$ & 7 & ترشد لاكتشاف المو اهب لدى الطلاب. & $\Lambda$ \\
\hline مهر & $\cdot, \wedge \%$. & $\varepsilon, .4$ & $\bar{v}$ & تحفز على استثمار الوقت لدى الطلاب. & 7 \\
\hline مه & $1, .4 \Lambda$ & $\overline{r, \uparrow}$ & 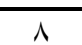 & تسهر في الكثف عن نقاط الضعف لدى الطلاب. & $\Gamma$ \\
\hline مه & $1,1 \lambda 1$ & $r, \Delta r$ & 9 & اكتثاف السلوك اتجاه الآخرين لاى الطلاب. & 9 \\
\hline مهر & $\cdot, \wedge 41 \cdot \vee$ & $r, q \leqslant$ & & 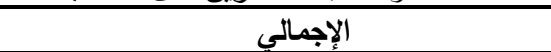 & \\
\hline
\end{tabular}

$$
\text { يتضح من الجدول رقم (ع - 1): }
$$

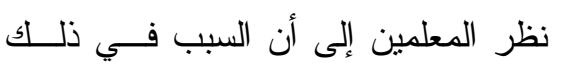

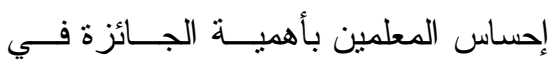

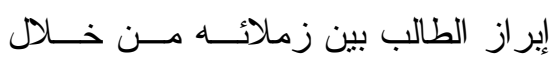

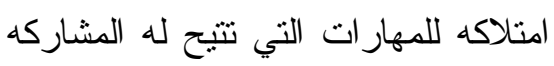

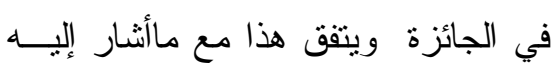

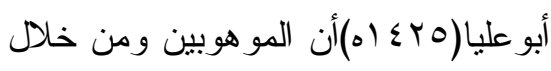

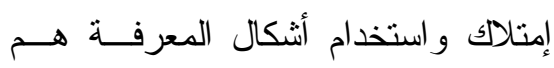

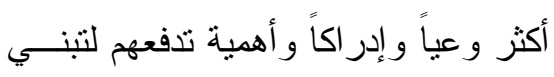

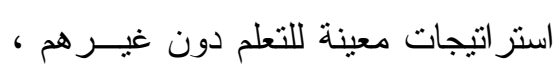

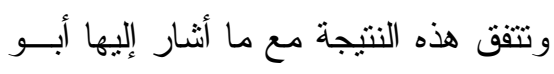

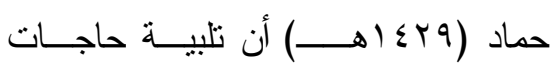

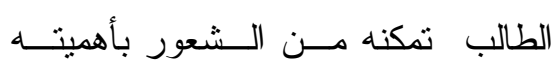
وينعكس هذا أمام زملائه ويكون قـادراً

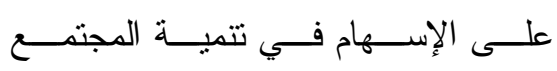

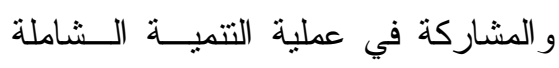
و اكتساب المعلومات من خلال المشاركة

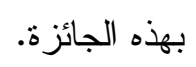

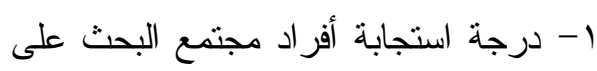

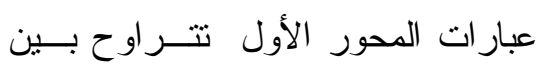
درجة "مهم جداً" ودرجة "مهم "، حيــث الأث

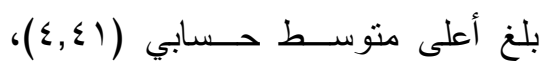

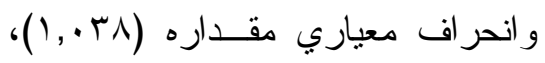

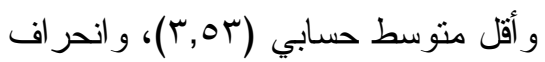

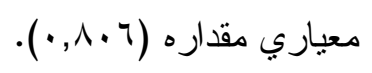

ץ- حصلت ثلاث عبار ات على درجة "مهم

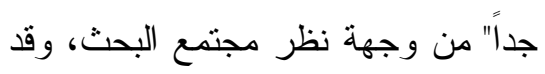

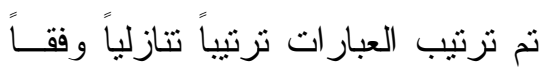
لمنوسطها الحسابي كما يلي:

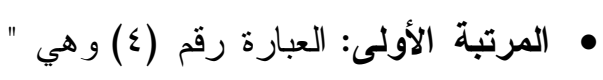

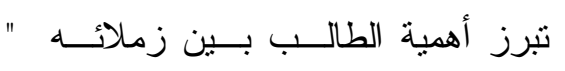

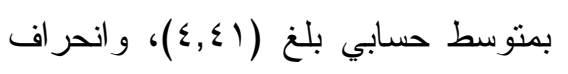

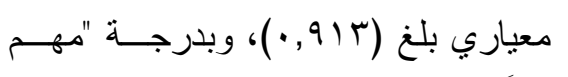

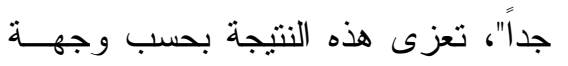


التركيز على تلقين المادة دون الأخـــذ

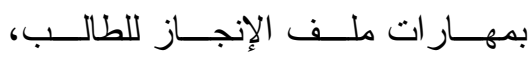

وتشجيع ودعم المعلمـين فــي تلبيـــة احتياج الطالب

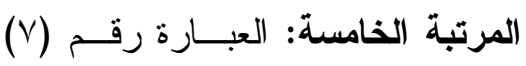

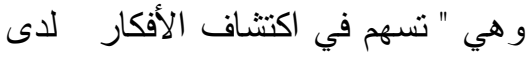

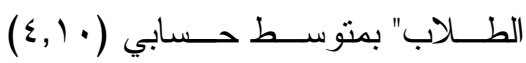

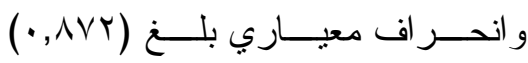
وبدرجة " مهم"، ويرى الباحث أن هذه

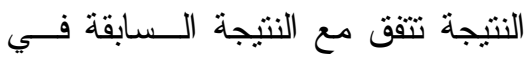
المرتبة الر ابعة حبــث أن دور جـائزة

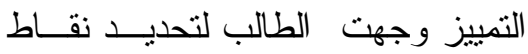

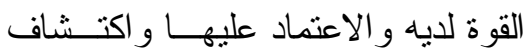
الأفكار المميزة أو قد يعزي الباحــث هذه النتيجــة إلــى استــشعار أهميــة

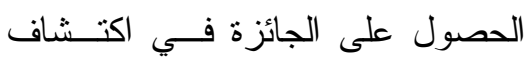
الأفكار ، ومن خلال حساب الانحـــر اف

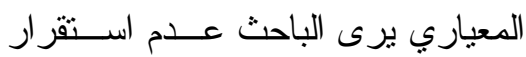

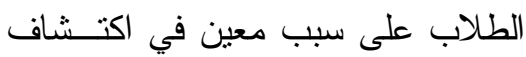

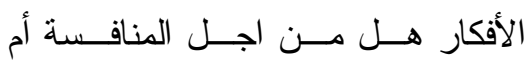
الاكتشاف فقط أم الظهور ومعرفة نقاط لاط

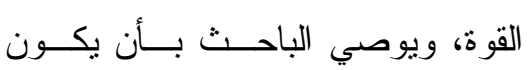
المنافسة في الجـائزة مبنــي بدرجـة كبيرة على الالتحاق بالدور ات التدريبية

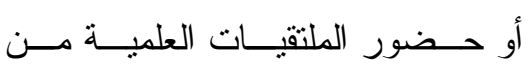

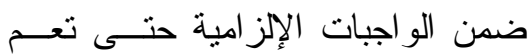
الفائدة.
• المرتبة الثانية: العبارة رقم (1) وهي "

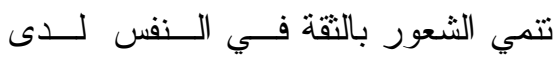

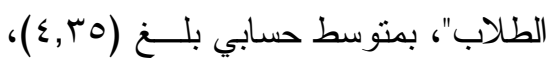

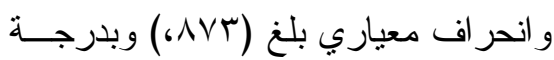

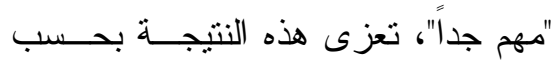
وجهة نظر المعلمين إلى أن السبب فــي لهي ذللك إحساس المعلمين بأهية الجائزة في تتمية الثقة في النفس وفي تكــوين روح

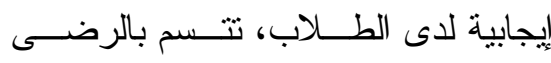

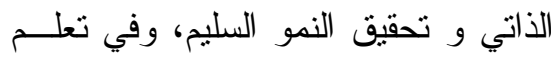
مهار ات جديدة ومنافسة مميزة للحصول ولموليو على الجائزة. وتتفق هذه النتيجة مع مهــــا

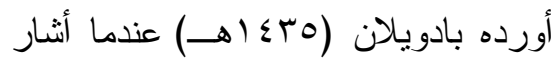
بأن ما يمتلكه الطالب من رغبة داخليــة لاكتشاف ما بمتلكه تعيد بناء ذاته ليصبح إنساناً ذو ثقة عالية قوية . المرتبة الثالثة: العبارة رقم (0) وهي " تسهم في المحافظة على الانجــاز ات

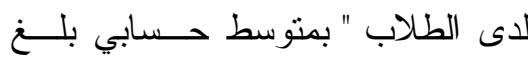
(

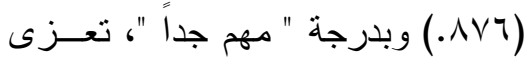
هذه النتيجة بحسب وجهة نظر المعلمين

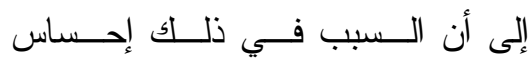
المعلمين بأهمية الجائزة و إسهامها في المحافظة على الانجازات لدى الطلاب

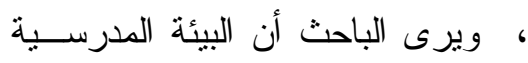

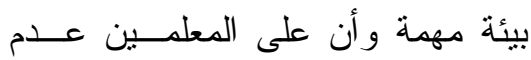


المرتبة الثامنة: العبارة رقم (؟) وهي "تسهم في الكثف عن نقــاط الــــف لدى الطلاب." بمتوسط حسـسابي بلــنغ

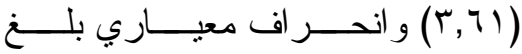

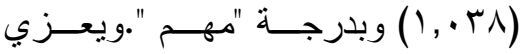
الباحث أن المعلمين يرون أن الجـائزة تظهر للطلاب نقاط الضعف لديهر مسن خلال معايير الحصول علـى جـائزة التميز ومحاولة إصلاحها وتقويمها. المرتبة التاسعة: العبارة رقم (9) وهي " اكتثاف السلوك اتجاه الآخرين لـدى لـى لـ

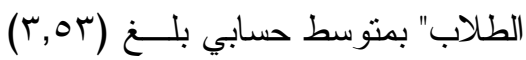

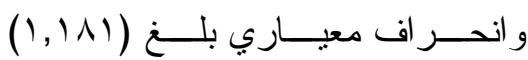
وبدرجة "مهم "، ويعزي الباحث هـــه

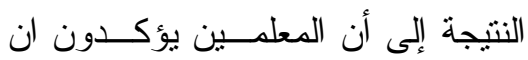

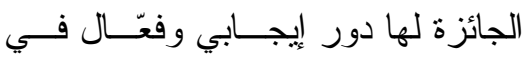
توجيه السلوك لدى الطلاب خاصة وأن

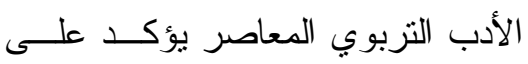

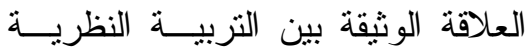
و السلوك لدى الطلاب تجاه الآخرين، فلم يعد هناك تفريق بينهمـــا وكأنهــــا جزئين متصلين، ،و إنما أصبح ينظـــر إلى الــسلوك باعتبــاره نـــاتج عمليـــة التدريس، ويزيد من مهار ات الاتــصلال بين المعلمين و الطلاب، ويرفــع مــن مهن مستوى العطلية التعليمية، بل ويـساعد
المرتبة السادسة: العبــارة رقـم (^)

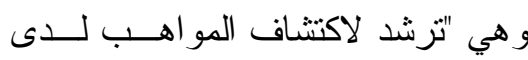

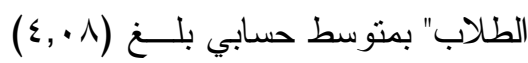

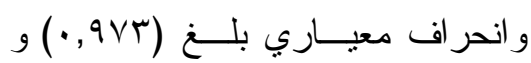

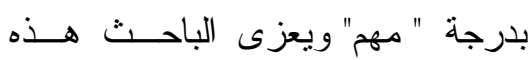

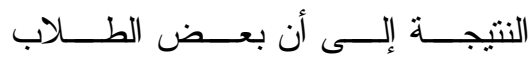

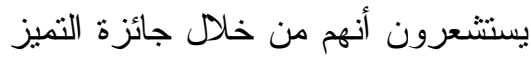
يكتشفو ا ذاتهم منها أو أنها ترشدهم إلى لى

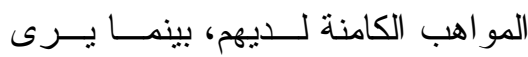
البعض أن عدم النشجيع و التنافس فــي لبن

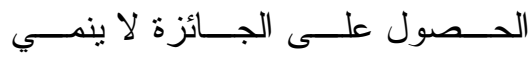

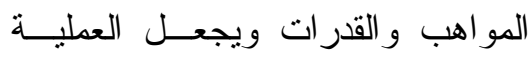
التعليمية تقليدية وروتينية لا تتيــر و لا ولان

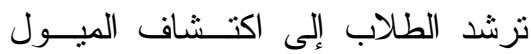
المو اهب و القدر ات. المرتبة السابعة: العبارة رقم (آ) وهي

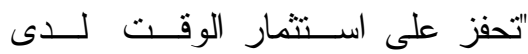
الطلاب " بمتوسط حسابي بلغ (7 •, ع)

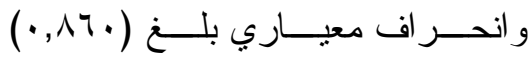
وبدرجة "مهم"، ويعزى الباحث ذلك إلى

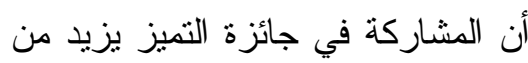

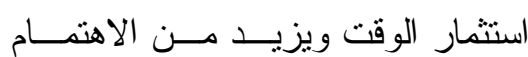

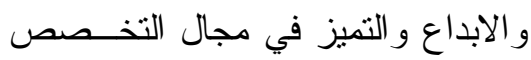

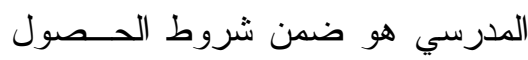
على الجائزة وقد يكون هناك سبب آخر لترون

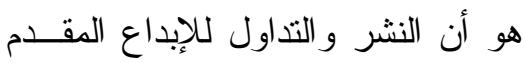
من الطلاب يحتاج لوقتاً وجهداً أكبر . 
تحفيز الأداء، وتؤكد هذه النظريات علــى أن

على حل ما يعترض من مشكلات فـي

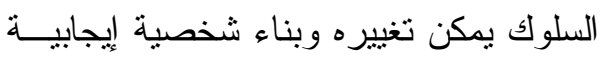

الميدان التعليمي.

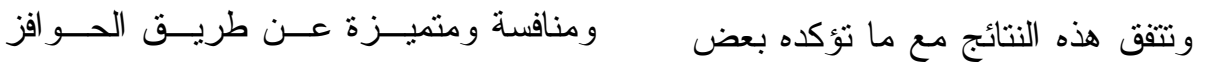

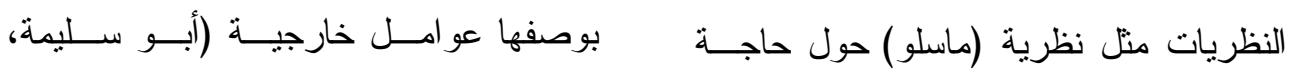

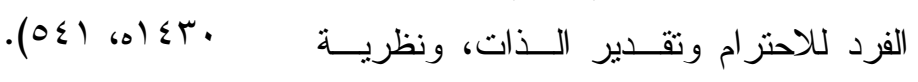

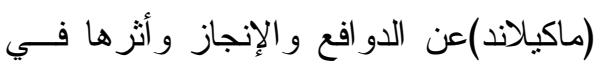

ץ-إجابة السؤال الثاني: ما إسهام جائزة التعليم للتميز في تنمية (تطوير الذات) لــــ طـلاب

المرحلة الثانوية ؟ أبواله

جدول (ع - r) يوضح المتوسطات الحسابية والاتحر اف المعياري لترتيب عبارات المحور الثاني

\begin{tabular}{|c|c|c|c|c|c|}
\hline اللفظية الالة & 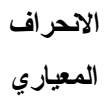 & 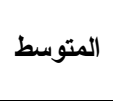 & 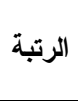 & 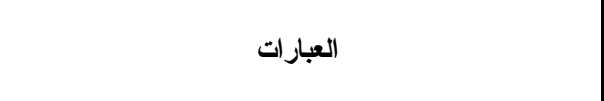 & b \\
\hline مهم جدا & $\cdot, \vee>79$ & $\varepsilon, r_{0}$ & 1 & تتمي الجو انب العلمية المكتسبة لدى الطلاب. & 1 \\
\hline مهم & $1, \cdot r \leq$ & $\varepsilon, 19$ & r & تحفز على استخدام تقنية المعلومات و الاتـصـالات لــدى & r \\
\hline همج & $\cdot, \vee \vee 9 \wedge$ & $\varepsilon, 1 V$ & r & نسهم في اكتساب مهار ات جديدة لدى لطلاب . & 7 \\
\hline مهم & .914 & $\varepsilon, 14$ & $\varepsilon$ & تتمي الموهبة لاى الطلاب. & $\varepsilon$ \\
\hline 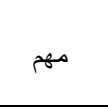 & $\cdot, 941$ & $\varepsilon, \cdot 9$ & 0 & 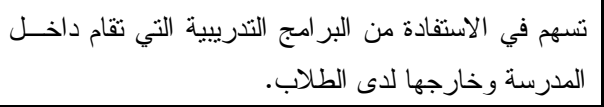 & v \\
\hline مهم & $\cdot, 9 \leq \varepsilon$ & $\varepsilon, \cdot 7$ & 7 & وتحفز على المشـاركة في الندو ات و المحاضـــر ات داخــل & r \\
\hline مهم & $1, .01$ & $\varepsilon, \ldots$ & $\mathrm{v}$ & تعزز الجانب السلوكي لدى الطلاب. & 9 \\
\hline مهم & $1, \cdot 7 \varepsilon$ & r,qv & $\wedge$ & تحفز على العمل بروح الفريق لدى الطلاب. & $\wedge$ \\
\hline مهم & $\cdot, 997$ & r,A & 9 & نتمي الهو اية لدى الطلاب. & 。 \\
\hline 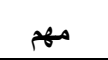 & ., & $\varepsilon, 1 V$ & & 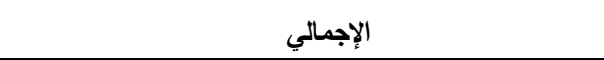 & \\
\hline
\end{tabular}

$$
\text { يتضح من الجدول رقم (؟-r): }
$$

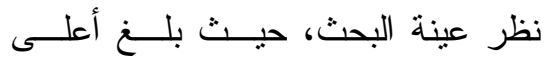

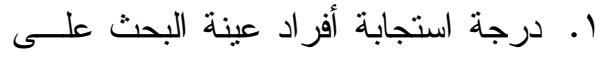

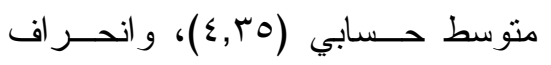

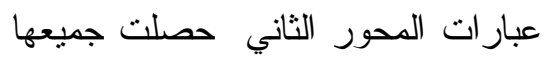

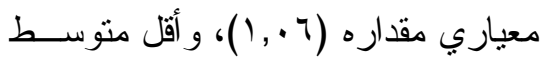
على درجة "مهم جداً- مهم " من وجهة 
التتمية العلمية من أجل المنافسة علـى

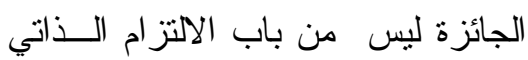

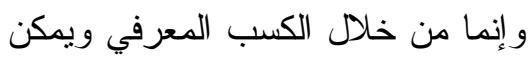

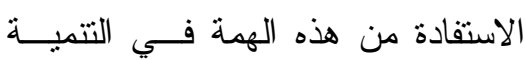

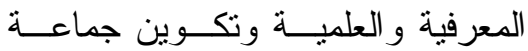
الطلاب المبدعين و المميزين. و هذا مــــا

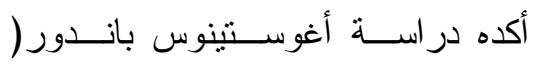
ــــA Agustinus Bandur خلال أهمية نظام الإدارة الذانتــة فـي

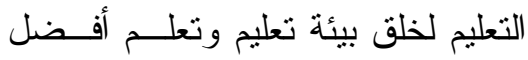

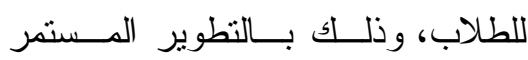
و التدريب في مجال الإدارة و القيادة.

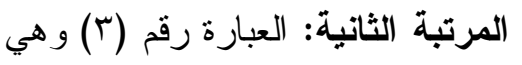

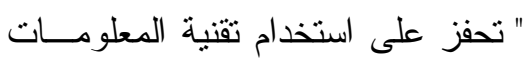

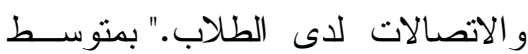

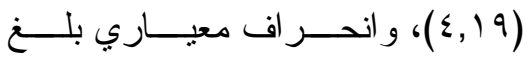

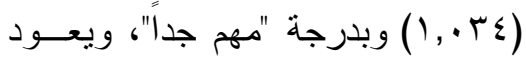
السبب في ذلك لأهمية استخدام تقنيــة

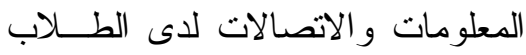

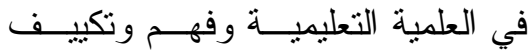

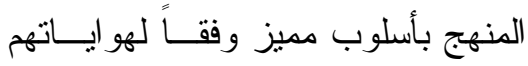
وزمنهم التكنلوجي، وبالتالي فإن هــــا يساعدهم على المنافسة العملية التعليمية

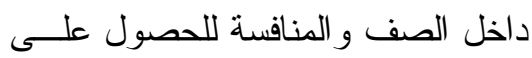

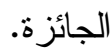
م المرتبة الثالثة: العبارة رقم (؟) وهي "

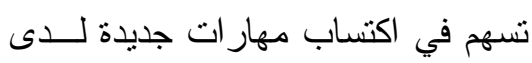
الطلاب " بمتوسط (
حسابي (r,^v)، و انحــر اف معيــاري

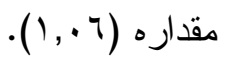
r. حصلت بعض العبار ات علـى درجــة

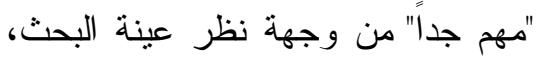

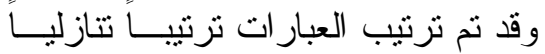
وفقاً لمتوسطها الحسابي كما يلي: • المرتبة الأولى: العبارة رقم (1) وهي

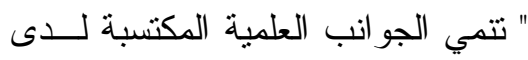

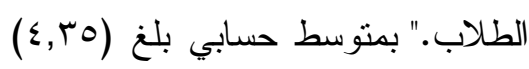

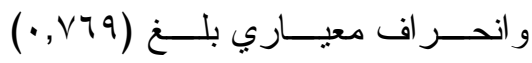
وبدرجة "مهم جدا"، ويعزو الباحث ذلك أن الجائزة تتمي لدى الطلاب الجوانب

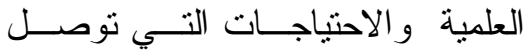
الطالب للحصول على الجائزة بالــشكل المناسب، وكــللك يــستطيعو ا تخيـلـل الموقف التعليمي للارس فهـــ يقومـــوا

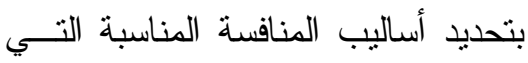
تساعدهم على تحديد معطيات الجوانب

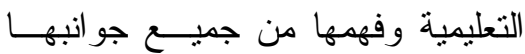
المعرفية و السلوكية و الوجدانية، ويرى

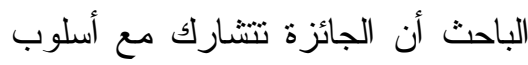

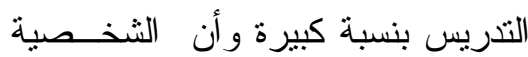

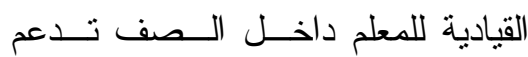

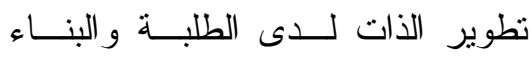

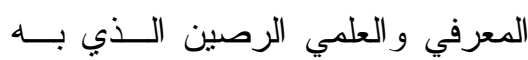
يستطيعو ا المنافسة الفوز على جـائزة

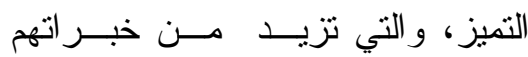

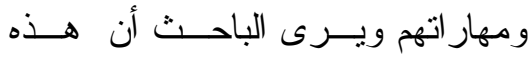


ذالتعليمية وتتمي المو اهب لديهح وتطوير

ذاتهم.

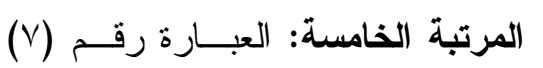

و هي " تسهم في الاستفادة من البـــر امج

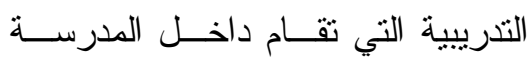

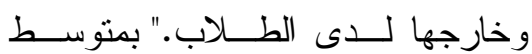

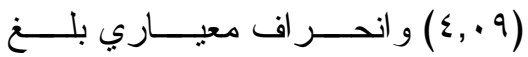

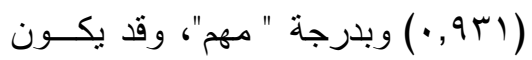

سبب ذلك لما للجائزة من إسهام كبيــر

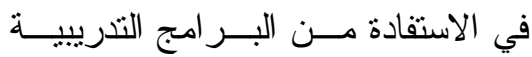

ودور هذه البر امج في تحسين العمليــة

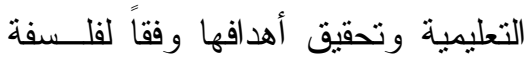

التربية المنبثقة من فلــسفة اجتماعيـة قائمة على التطوير المجتمعي والــذاتي و هـــا يــدعم الرؤيسـة الاســـتر اتيجية

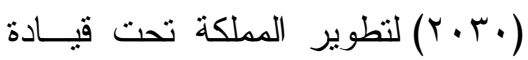
خادم الحرمين الثرفين الملك سلمان بن

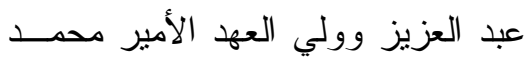
بن سلمان وفقهم الله للخير و التطــــير للبلد ، و لأهمية البر امج التدريبية التي ولفي

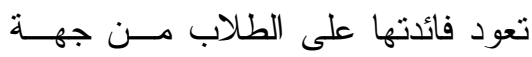

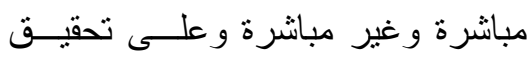

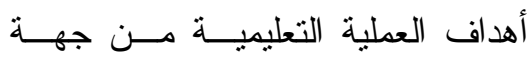
أخرى.

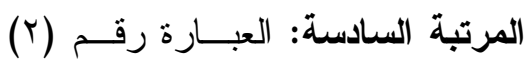

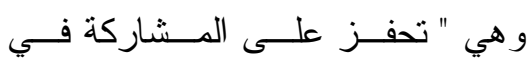

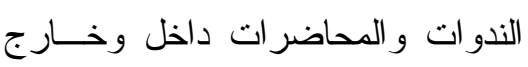

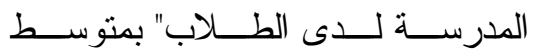

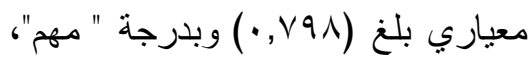

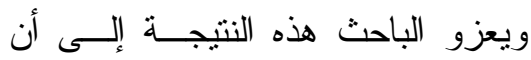
جائزة التميز تساهم بشكل كبيــر فــي لئهي تطوير المهارات الموجودة لدى الطلاب و اكتساب مهار ات وقــدرات جديــدة

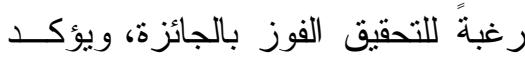
الباحث هنا علـى المعلــم بالاهتمــام بالتخطيط للارس بما يساعد الطـــلاب

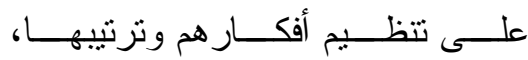

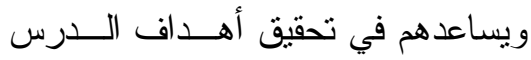

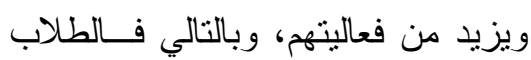

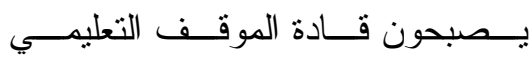
و المهتمين بالتعلم. • المرتبة الرابعة: العبارة رقم (ع) وهي بهي

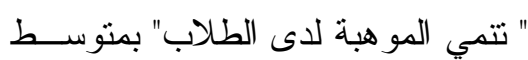

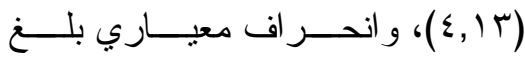

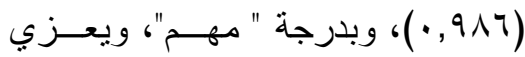

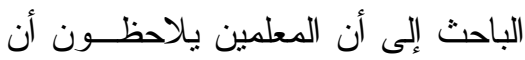

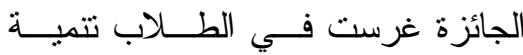

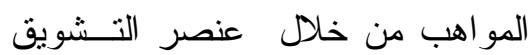
الذي عززته الجائزة كما يرى الباحــث

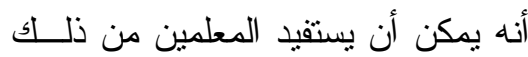

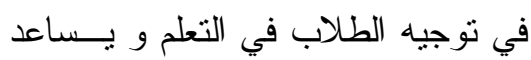

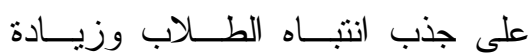

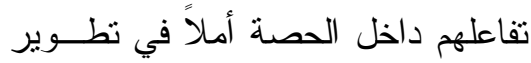

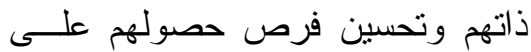
الجائزة وبالتالي يزيد من فعالية العملية 


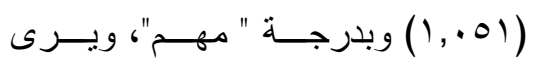

الباحث أن ربط المحتــوى التعليهـي

بالسلوك لدى الطلاب يساعد على تثبيت

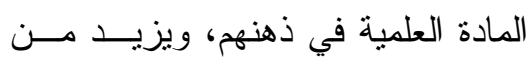
تفاعلهم واتجاههم، ويؤكد على قدرتهم وهيل

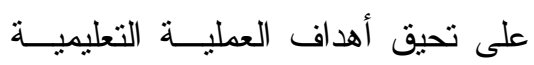

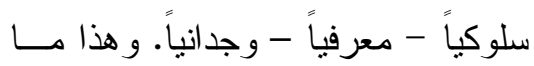

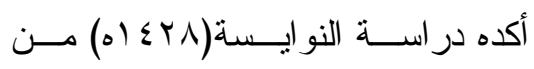
خلال التفاعل بين البرنامج الإرشــادي

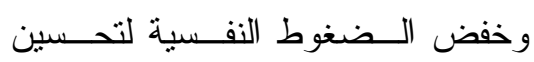
مستوى مفهوم الذات.

• المرتبة الثامنة: العبارة رقم (^) وهي لوني

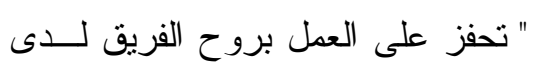

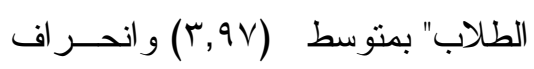

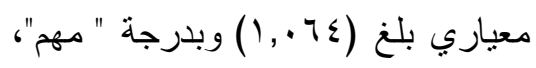

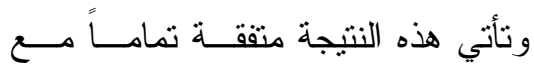
سابقتها فمع تعزيز الجانب الـسلوكي لـاني

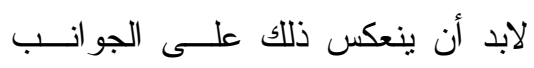

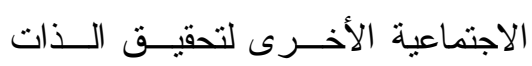
وتطويره من خلال العمل بروح الفريق

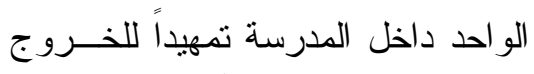

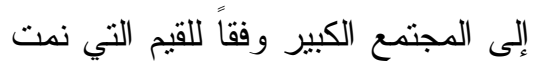

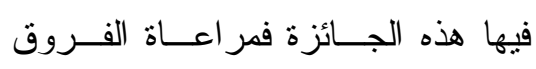

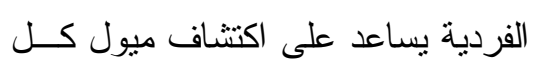
طالب وبالتالي نوظيفها في العمل بروح الفريق الواحد داخل العملية التعليميــة وخارجها.

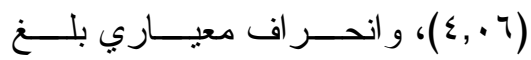

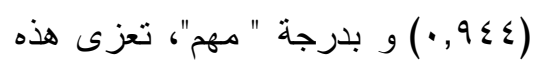

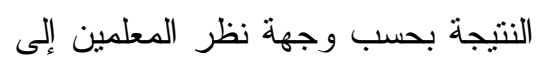
أن السبب في ذللك إحسـساس المعلمـين

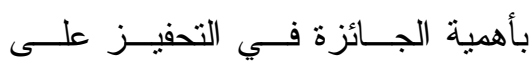
المشاركات وفي الندو ات و المحاضر ات

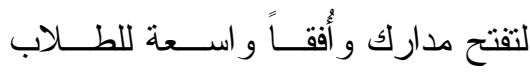

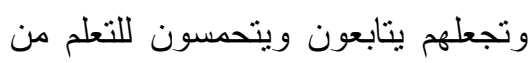

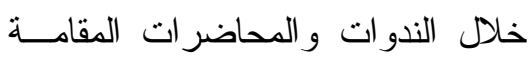
بالمدرسة أو حتى خارج المدرسة سعياً منهم في تطوير قدر اتهم وذواتهم بمـــا

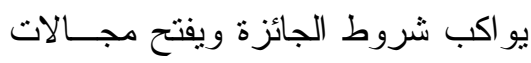
معرفية وذاتية متعددة وبأساليب متتو عة

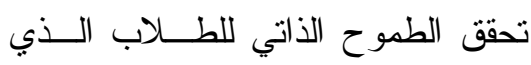
غرسته فيهم هذه الجائزة في البحـــث

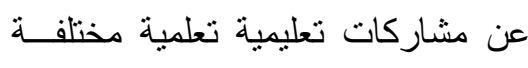

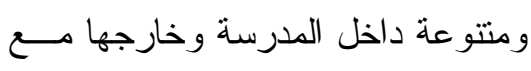
ما يتبعه من القدرة على توظيف هــــه دئه

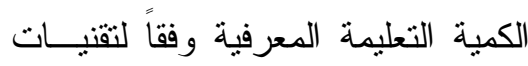
مناسبة للمحتوى التعليمي الذي يمكنهم

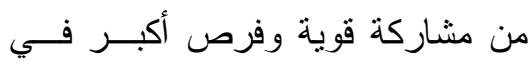

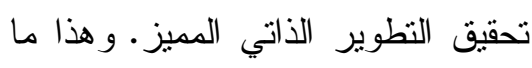

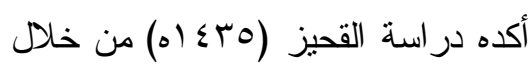

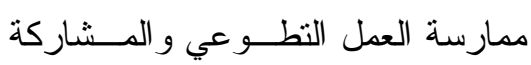
المجتمعية. • المرتبة السابعة: العبارة رقم (9) وهي " تعزز الجانب السلوكي لدى الطلاب."

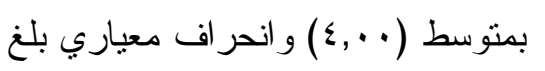


تطوير ذاتهم ايجابياً ومسساعدتهم فـي

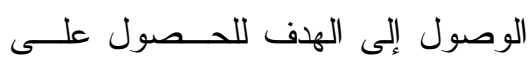
الجائزة، و الاستمر ارية في بناء الهو اية الطولية للطلاب وفقاً لقدرات الطلاب وسماتهم

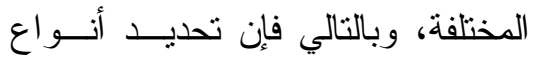
الهوايات المختلفة من تطوير الذات بما

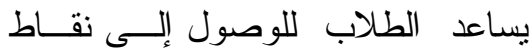

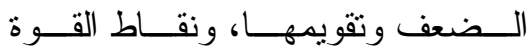

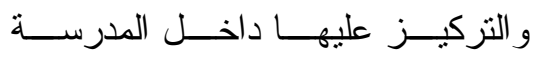
وخارجها، و بالتالي يجعل منهم قـــادة

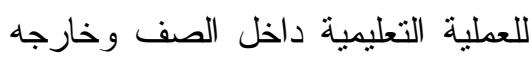
من خلال توجيههم ومسساعدتهم فـي نطوير ذاتهم و هو اياتهم المختلفة. إجابة السؤال الثالث: ما إسهام جائزة التعليم للتميز في تنمية (التطلعات المهنية) لاى طــلاب المرحلة الثانوية؟ الهواله جدول (؟ - ب) يوضح المتوسطات الحسابية والاتحراف المعياري لترتيب عبارات المحور الثالث

\begin{tabular}{|c|c|c|c|c|c|}
\hline اللالالة & الالمعراف & المتوسط & الرتبة & 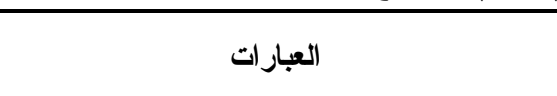 & p \\
\hline مهر & $1, .09$ & $\varepsilon, \cdot 7$ & 1 & تسهم في نتمية الميول المهنية لدى الطلاب. & $r$ \\
\hline 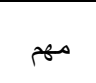 & $1, \cdot \varepsilon \cdot$ & r, १ะ & r & 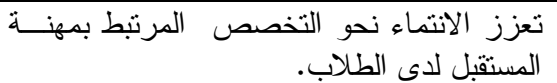 & r \\
\hline مهر & $1, \cdot 1 \mathrm{~V}$ & r,qr & r & 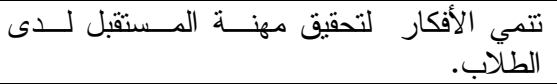 & $\wedge$ \\
\hline 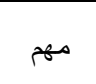 & $1,1 \ldots$ & $r, q 1$ & $\varepsilon$ & تلطلاب. على الالتز ام بأخلاقيــات المهنــة لــدى & 7 \\
\hline مهر & $\cdot, 9 Y 1$ & r,q1 & $\varepsilon$ & لدعز الطلاب. لاطلاع على كل جديد يهنم بالتخـصص & $\varepsilon$ \\
\hline مهر & 1,119 & r, ^o & 0 & تحفز على اختبار مهنة المستقبل لدى الطلاب. & 1 \\
\hline مهر & שד & $r, v q$ & 7 & 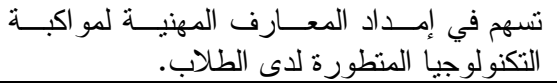 & 0 \\
\hline مهم & ו ו ו & $r, v r$ & V & لدى الطلابل. على التكيف مع الذات في مهنة المستقبل & V \\
\hline 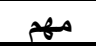 & $\cdot, 9 r \wedge$ & $r, \wedge q$ & & الإجمالي & \\
\hline
\end{tabular}

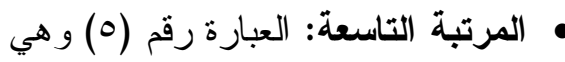

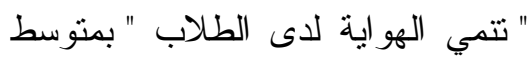

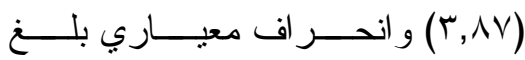

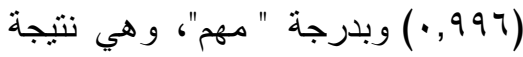
مطابقة لما جاء في المر اتـب الــسابقة ضمن المحور نفـسه. فالجـائزة مسـن وجهة نظر المعلمين تتمي الهواية لدى

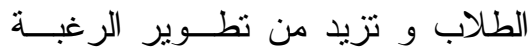

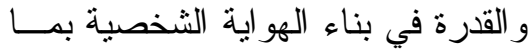

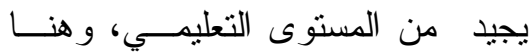
يحث الباحث المعلم بالاستفادة من هذه لهن

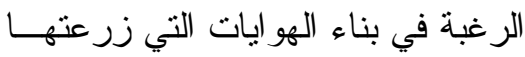
الجائزة، ومحاولة مساعدة الطلاب في لياء 


\section{يتضح من الجدول رقم (ع-ب):}

و الاقتـــــــادية و الفكريـــــة و الثقافيـــــة

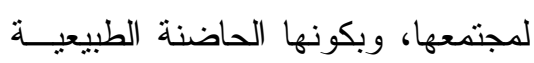

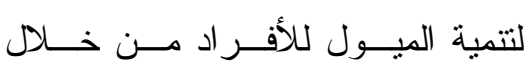

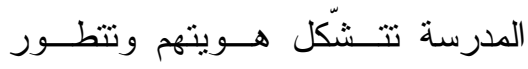

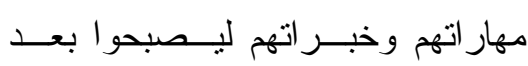

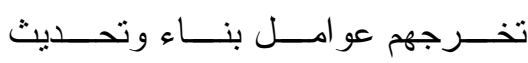

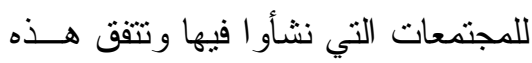

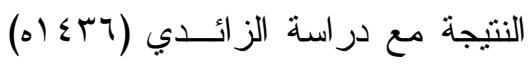

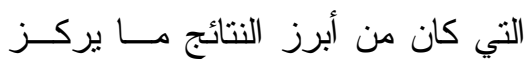

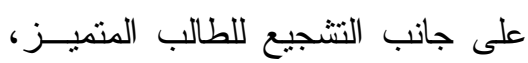
وكذلك تحقيق معيار (الثقافة المؤسسية) بدرجة ممارسة بشكل كبير جداً من قبل مديري المدرسة، وكان من أبرز النتائج

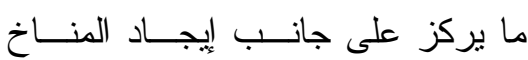

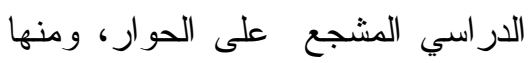
ما يحقق إحدى المعايير بشكل مت أخر كإنثر الك أعضاء المجنمع المدرسي في لهي

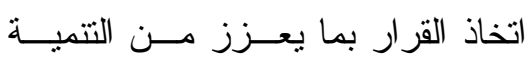
المهنية لكل طالب وفقاً لتصنيفات المهن

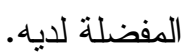
• المرتبة الثانية: العبارة رقم (ץ) وهي " تعزز الانتماء نحو التخصص المرتبط

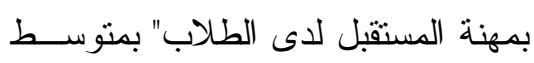

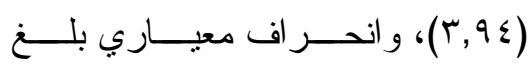

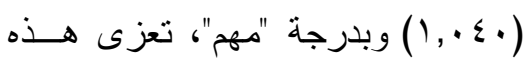
النتيجة بحسب وجهة نظر المعلمين إلى

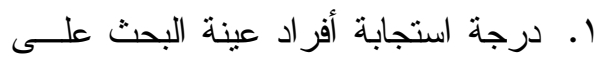

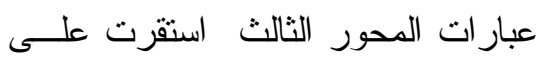
درجة "مهم"، من وجهــة نظــــر عينــة

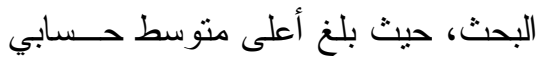

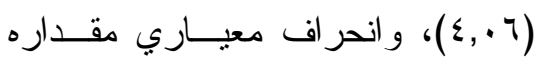

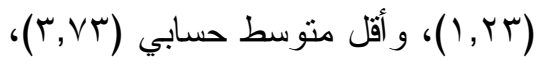

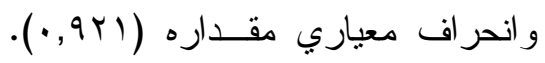
وقد تم نزتيب العبار ات ترتيــاً تتازليــاً وفقاً لمتوسطها الحسابي كما يلي: • المرتبة الأولى: العبارة رقم (r) وهي

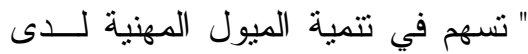
الطلاب " بمتوسط حسابي بلغ (T •, ع)

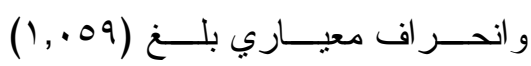

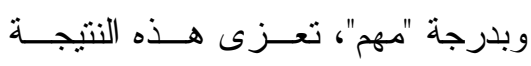

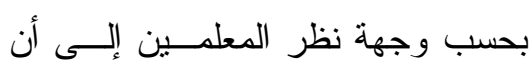
السبب في ذلك إحساس المعلمين بأهمية

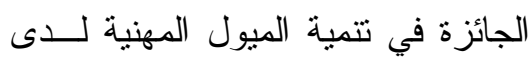

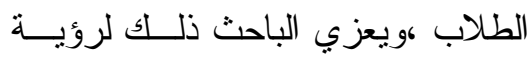
الطلاب ور غبتهم المستمرة في اكتشاف

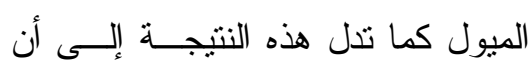

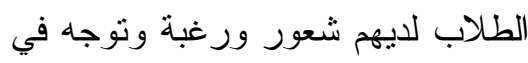
الاهتمام بتطوير و تتمية الميول المهنية

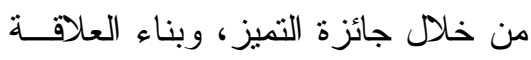

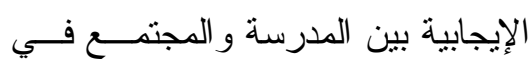
إطار العلاقة الوظيفية المتز امنة كــون

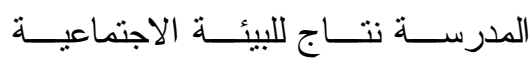


بحسب وجهة نظر المعلىـين إلـى أن فئس السبب في ذلك إحساس المعلمين بأهمية

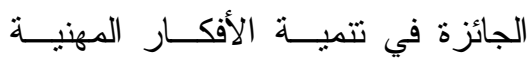

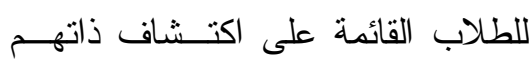
بشكل سليم وتتميتها وتطوير ها بشكل

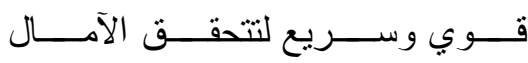

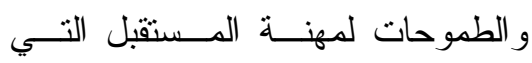

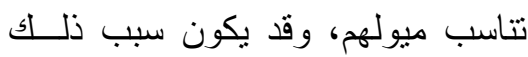

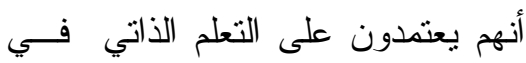

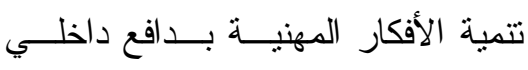

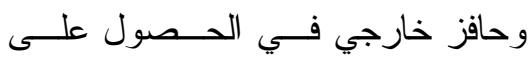
التطور المهني والجائزة معاً، هذا يولد لديه روح التجديد و الابتكار ، وتتفق هذه ولهن

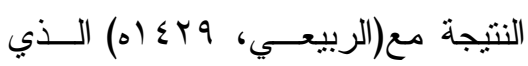

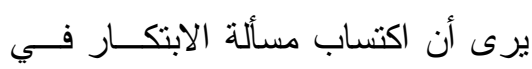

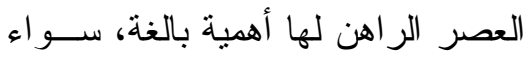

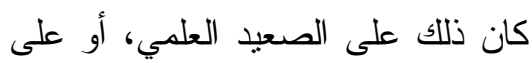

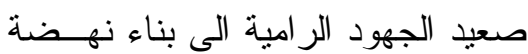
وطنية، وعلى صــعيد ابتكــار أدوات تعليمية لبناء عالم المعرفة الحديث الذي وعي الدي يمثل الإبداع والابتكار عاملاً رئيـسياً

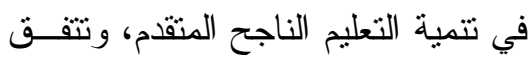

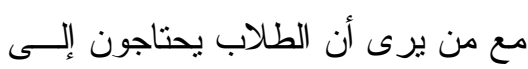

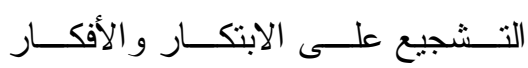

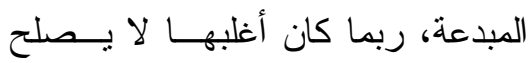

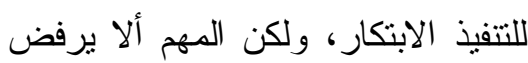

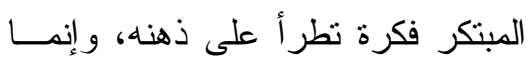

أن السبب في ذلك إحسـساس المعلمــين بأهمية الجائزة في تعزيز الانتماء نحو التخصص ويعزي الباحث هذه النتيجة إلى أن الطلاب لديهم التصور بــشكل

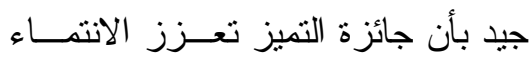

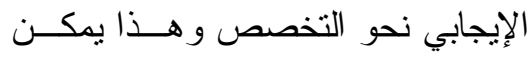

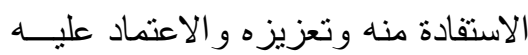

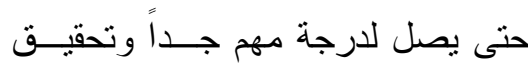

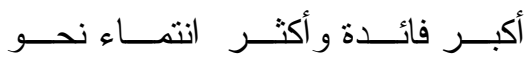
التخصص ومو اكبة التخصصات التـي ولي يحتاجها سوق العمـلـل ، خاصــــة وأن المملكة العربية السعودية أطلقت رؤية لون

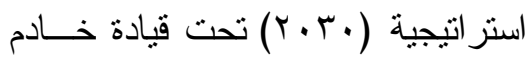
الحرمين الثريفين وولي عهــده التـي التي

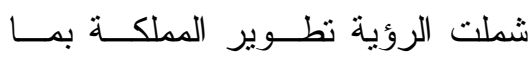
يجعلها منافسة عالمياً في كافة المجالات ويمكن الاستفادة من الخبرات المتقدمة

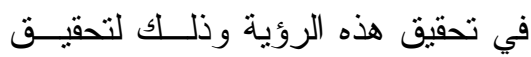

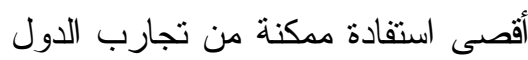

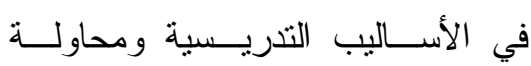

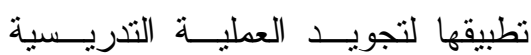
و الاستفادة أكبر من نتائج جائزة التميز . • المرتبة الثالثة: العبارة رقم (^) وهي التي "تتمي الأفكار لتحقيق مهنـــة المـستقبل

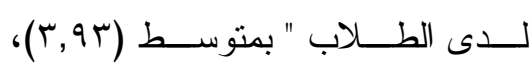

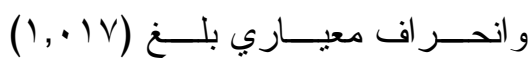

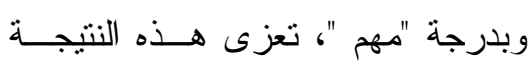


القيم التعليمية التي تعزز في الاطـــلاع

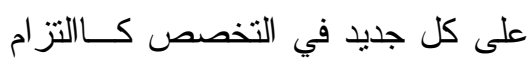

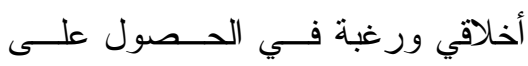
الجائزة أو لظهور المبدعين و المتميزين

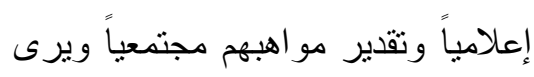

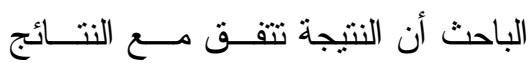
السابقة وتتفق هذه النتيجة مع دراســـة

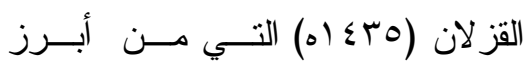

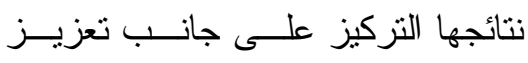

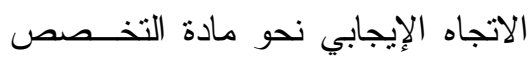

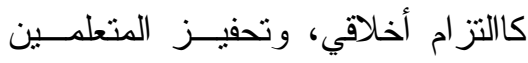

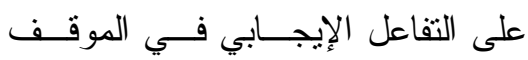
التدريسي، وتحديد الخبــرات الــــابقة

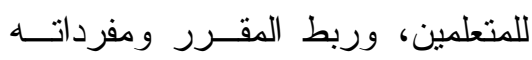
بو اقع المتعلمين وبيئتهم، وتتمية الثعور ولئر بالمسؤولية لدى المتعلمين.

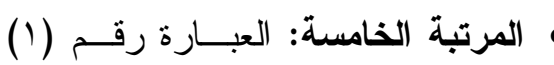
وهي " تحفز على اختيار مهنة المستقبل

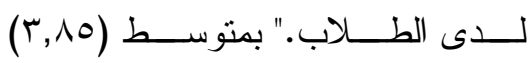

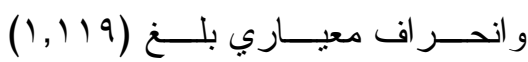

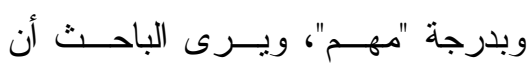

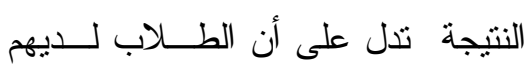

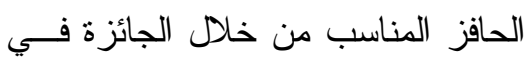
اختيــار مهنـــة المــــتقبل المناســـبه و المتو افقة مع نقاط القوة لديهم بل مـــع جو اهر نقاط القوة التي اكتثفو ها مــن خلال الحافز الخارجي وهو الحــصول
يقع عليه مهمة تجميع أكبر قـدر مـنـ

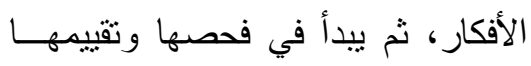
وتصفيتها، فالعبرة هنا بمعــدل إنتــاج الأفكار خلال فترة زمنية معينة.

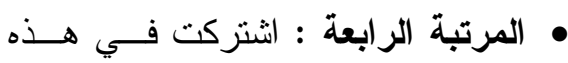

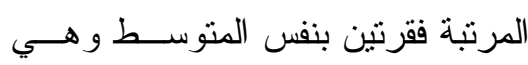

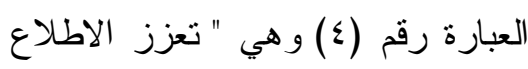

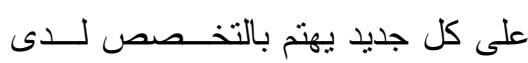

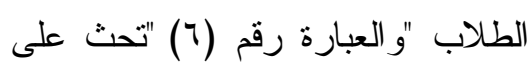

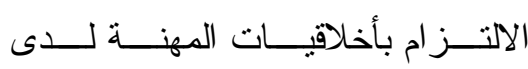

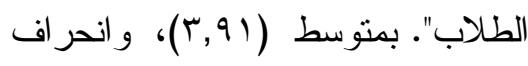

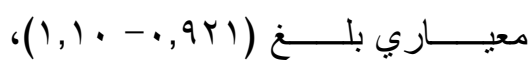

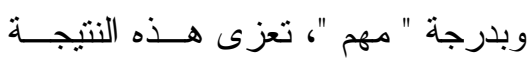

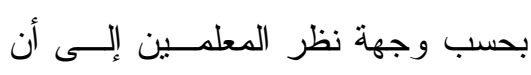
السبب في ذلك إحساس المعلمين بأهمية

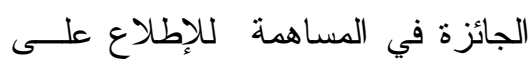
كل جديد في التخصص لدى الطــلاب من خلال كافة وسائل التربية النظامية

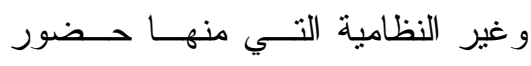

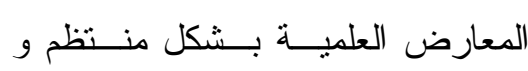

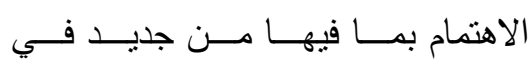
التخصص العلمي، أو قد يعود الــسبب

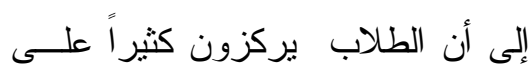
الأنشطة الصفية الطلابية و بناء الذات

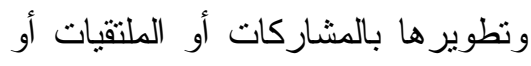

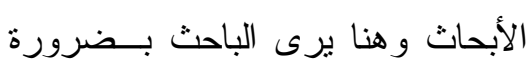
تركيز الإعلام التزبوي في تعزيز هذه 
هناك علاقة قوية بين الحوافز المادية، و الحوافز المعنوية، والتي لا تقل أهمية عنها، وجود معوقات تو اجه اســتخدام

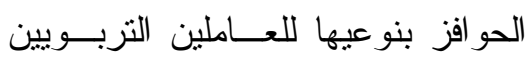
بمختلف فئاتهم، إن مستوى الرضا لدى لئ لاعي

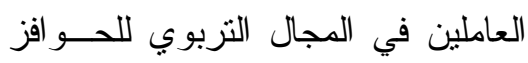
عالياً، وخاصةً فيما يتعلق بالإعلان عن فئري الحو افز في مستوى المدرســـة، وكــان

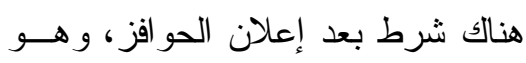
العدالة بين العاملين في تقدم الحو افز . المرتبة السادسة: العبــارة رقــم (0) و هي " تسهم في إمداد المعارف المهنية

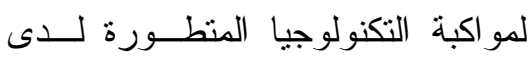

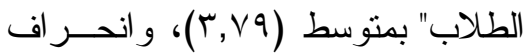
معياري بلغ (ب7979 •) و بدرجة " مهم

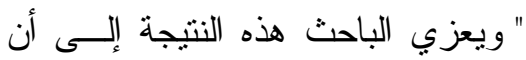

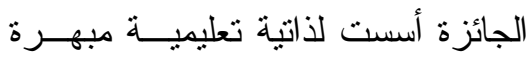
وعملاقة ومنافسة ومثابرة في الحصول

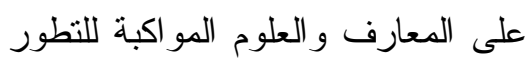
التكنولوجي وهو ما يتطلب من نطوير

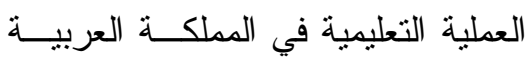

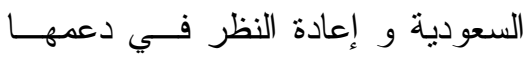

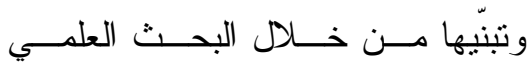

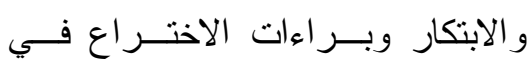

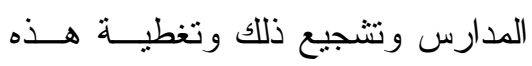
الإنجاز ات إعلامياً حتى تسود المنافسة ولفي

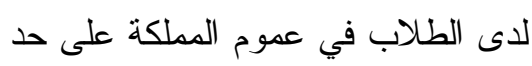

على الجائزة و أدى هذا الحـافز إلـى الاهتمام بالمهنة المستقبلية لهم وبنــاء

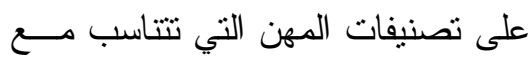
جواهر نقاط القوة لــديهم فــي تقــديم أدوات و أساليب و أفكار إبداعية تخــدم هذه المهن المستقبلية، وقد يكون مــرّد ذلك شعور الطلاب بأهمية الإبداع فــي وني اختبار المهن المستقبلية، أو قوة الدوافع الإباع

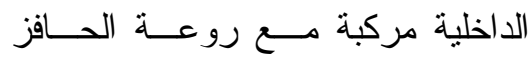

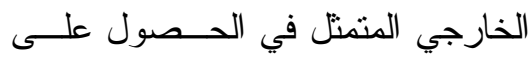
الجائزة ومن الدورات التدريبية التـي تبين أهمية الإبداع في اختيـار المهـن

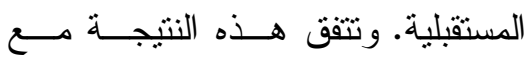

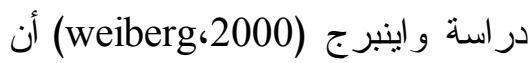
الحو افز المادية المستمرة و القائمة على تقارير الأداء تزيد من رغبة المعلمـين

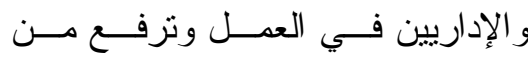
انتمائهم الوظيفي وتتفق أيضاً در اســـة

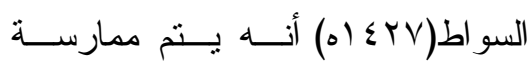
الحوافز التثجيعية مــن قبــلـ الإدارة

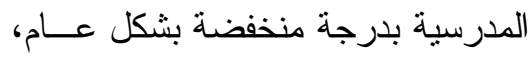

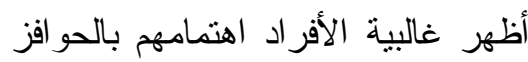

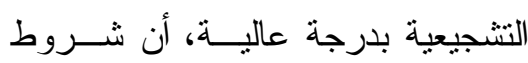
تفعيل الحوافز تطبق من قبــلـل الإدارة

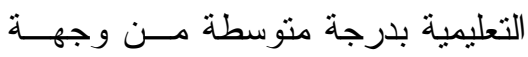

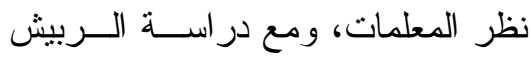

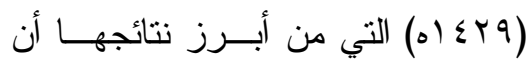


مهنة المستقبل لدى الطلاب" بمتوســ

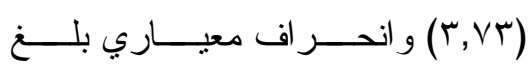

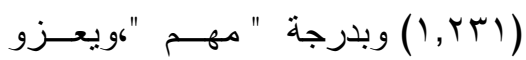

الباحث حصول هذه النتيجــة إلــى أن أن أنس

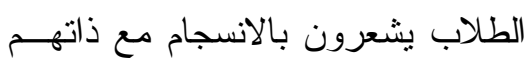

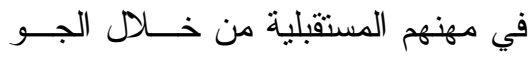

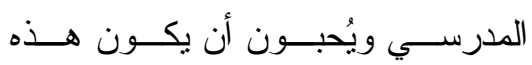

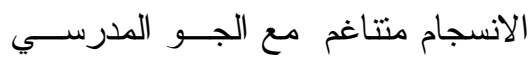

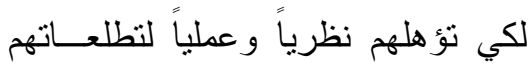
المهنية المستقبلية التي بدأوا في النتافس لهم

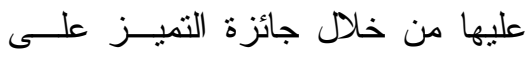
مستوى المدرسة و المنطقة للوصول إلى هنى إطار المملكة بشكل عام.
سو اء،، ويرى الباحسـث أنهـــا نتيجـــة منطقية لما سبق من المراتب الـسابقة

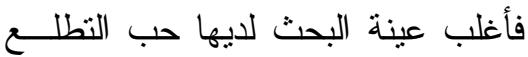
للأفكار وللأساليب الحديثـــة و الأدوات

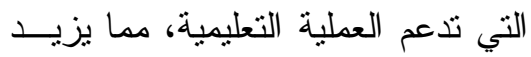
من وجود بر اءات اختراع في مجــال التخصص التدريسي وتتفق هذه النتيجة مع نظرية (ماكيلاند) دافعية الإنجاز إذ هدهي

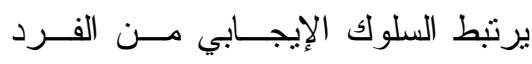

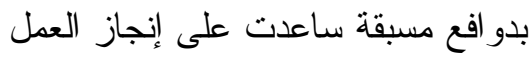

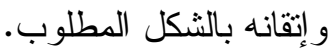

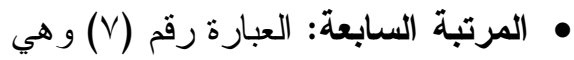

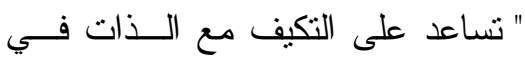

إجابة السؤال الرئيس: ما إسهام جائزة التعليم للتميز في التتمية الذاتية في جوانبهـــا الـثـلاث

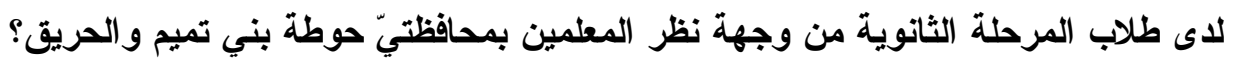
جدول (؛ - ؛ ) يوضح المتوسطات الحسابية والاحر اف المعياري لترتيب جميع محاور البحث

\begin{tabular}{|c|c|c|c|c|c|}
\hline اللالالة & 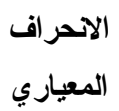 & المتوسط & الرتبة & العبار ات & P \\
\hline هم & 列, TVT & $\varepsilon, I V$ & 1 & 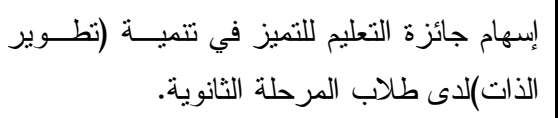 & r \\
\hline مهر & $\cdot, \wedge T 1$ & $r, q \leq$ & r & 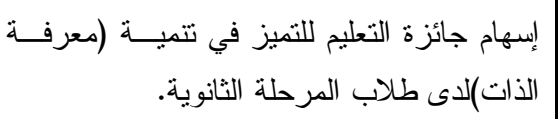 & 1 \\
\hline مهم & •, & $r, \wedge 9$ & $r$ & 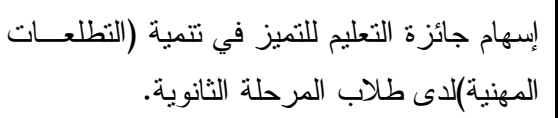 & $r$ \\
\hline مهم & $\cdot, v \leqslant r$ & $r, q r$ & & الإجمالي & \\
\hline
\end{tabular}

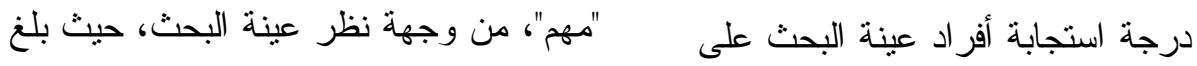

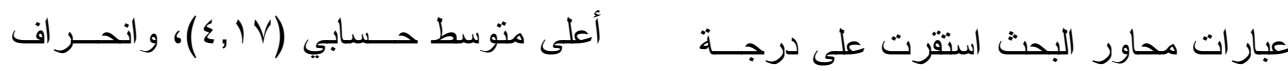


التي تساعده على النهوض و التطـــوير

$$
\text { (صص 10) (ص) (10) }
$$

• ومن ذلك يتضح أهمية تتمية الـذات لدى الطــلاب مــن خـــله تحـسينها وتطوير ها؛ لتحقيق الجودة في المعرفة،

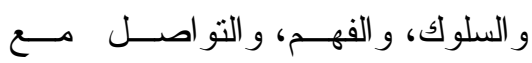

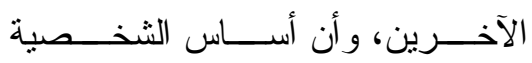
الإيجابية تتم من خلال العلاقة الإيجابية المفعلة مع الذات ومع الآخرين. • المرتبة الثانية: المحور رقم (1) وهي "المحور الأول : إسـهام جائزة التعلــيم للتميز في تتمية معرفة الذات" بمتوسط

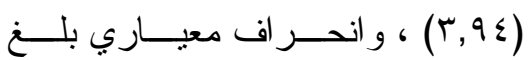

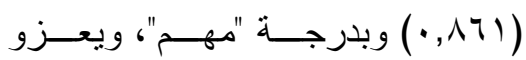
الباحث هذه النتيجة إلـى أن المعلمــين يرون أن على الطلاب لــديهم معرفــة

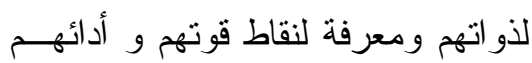
ومعرفة الذات ، أو قد بعزي الباحـــث هذه النتيجة إلــى أن المعلمــين لــديهم الرغبة في بناء علاقــات جيــدة لــدى الطلاب حتى تشتمر العملية الثزبويــة اللاصفية جنباً إلى جنب مع الأنـشطة الصفية لتلبية حاجات الطالب و الثعور بما بمتلكه من مهار ات ليكــون قــادراً

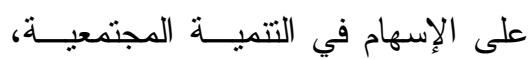
و الاستفادة مــن المنافـسـة الإيجابيـــة للجائزة في معرفة الــذات وتطويرهــــا
معياري مقداره (TVT, · • )، و أقــل متوســط

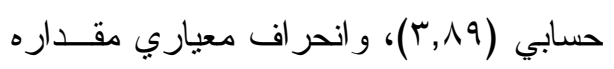

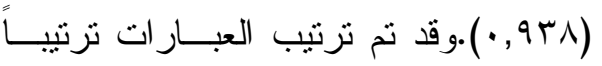
تتازلياً وفقاً لمتوسطها الحسابي كما يلي: • المرتبة الأولى: للمحور رقم (Y) وهو المحور الثاني : إسـهام جـــائزة التعلــيم للتميز في تتميــة تطـــوير الــذات. "

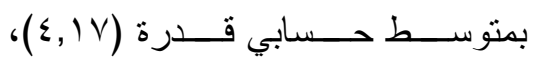

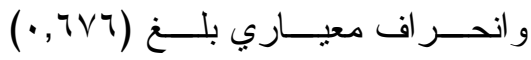

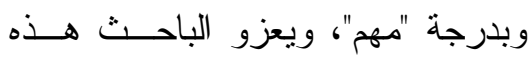
النتيجة أن المعلمين يرون أن الجـائزة لها دور في تطوير الذات لدى الطلاب

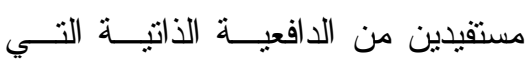
تعطيها الجائزة للطــلاب ويحـــاولون توجيه العملية التعليمية بما يزيــــ مــن تطوير الذات للطلاب، ويساعد الطلاب في التحديات التي تو اجههم من خــلال تتمية وتطوير ذو اتهم ، فهم يبحثون عن الجائزة و يبحثّن على نطوير قدارتهم و ذو اتهم وتتميتها بمـــا يتتاســب مـــع معايير وشروط الجائزة وهذا له الدور المستقبلي الجيد على الطلاب. وتتفــق وهن

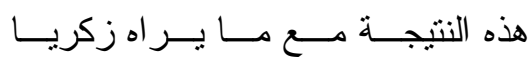

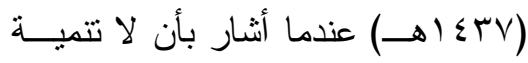
اقتصادية أو سياسية او اجتماعية دون تتمية الطالب، وذلك بتعليمـــه و تثقيفــهـ وتدريبه، على كل الفنون و المهــار ات، 
المرتبة الثالثة: للحور رقم (ץ) وهي " المحور الثالث : إسهام جائزة التعلــيم للتميز في تتمية التطلعــات المهنيــة."

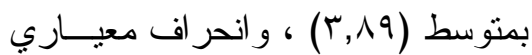
بلغ (^^و, •) وبدرجة " مهم"، ويعزو الباحث ذلك إلى أن المعلمين يرون أن أن الجائزة عززت لاى الطلاب بشكل مهم وكبير التطلعات المستقلية من اختيار التخصص المرتبط بالمهنة المسـتقبلية

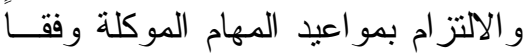

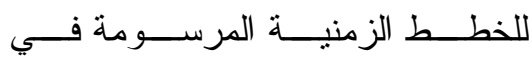

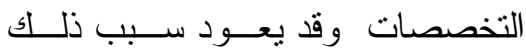
لمعرفة الطلاب بأهمية إنجاز الأعمــال و الو اجبات في مو اعيدها المحددة، وما يترتب على ذلك من تبعات في تحقيــق التطلعات المستقبلية. وتتفق هذه النتيجة مع كل من آونا (ona, 2015, p188) (Domenico, 2007, ودومينيكـــ من اونس (Arasaw, 2014, و وار اســاو p25) (Bora, 2016, p141) وبور ونار (p41) على أن الدو افع، و الطموحات الداخليـــة

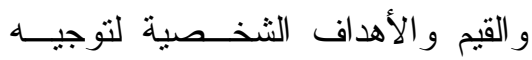

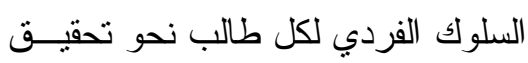

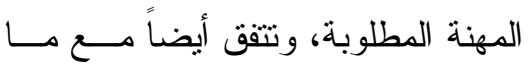

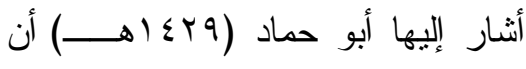

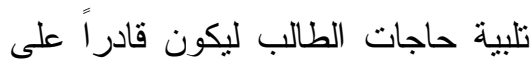
الإسهام في تتمية المجتمع و المــشاركة
وفقاً للقدر ات المناسبة و المبدعة بدوافع

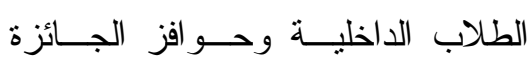
الخارجية لما ذلك من تأثنير إيجابياً على

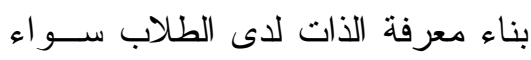
على المستوى التعليمي أو على مستوى الثخصي أو على المستوى الاجتماعي

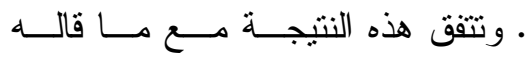

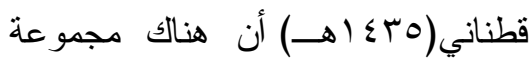
من العوامل لمعرفة الــذات ولتحقيــق

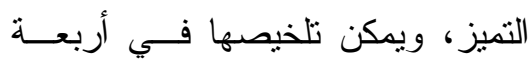

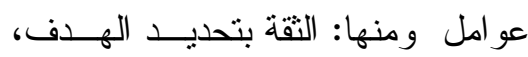
و المرونة لأنها قوة، و التحلي بالإصرار

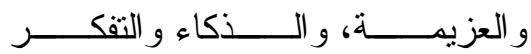

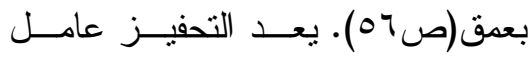
اساسي للتميز فليس بوسع أي طالــب لبع

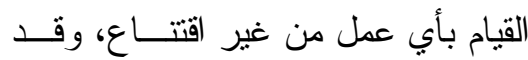

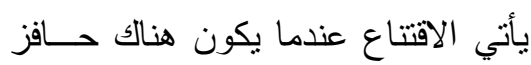
يدفعه للقيام بهذا الفعل، كما يجب على لهى لهن الطالب تحفيز ذاته لمزيد من النــشاط

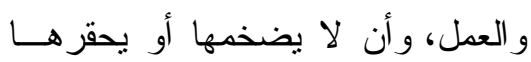

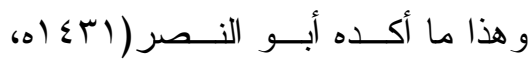

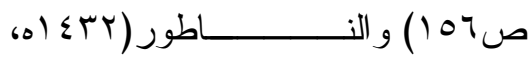
صع (1) بإنشارتهما بأنه كل ما يدور

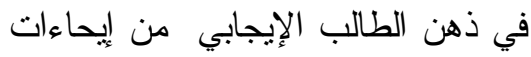
بناءه، تحقق له صور ذهنيــة محفـزة لذاته، ويساعد على اكتشافها وتتميتها. 
ونجاحهم من خلال التوجيه مــن قبـلـل المختصين بالإرشاد المهني.

وهنا يحث الباحث الإعلام التزبــوي

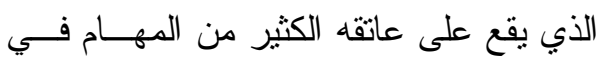
نشر ثقافة التتافس و الإبداع و التميز و الابتكار

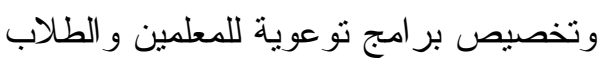

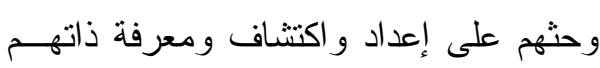

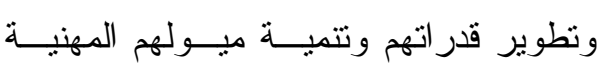
و التخصصية و إقامة الدر اســات و الأبحـــاث

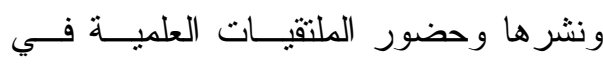

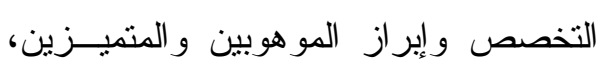

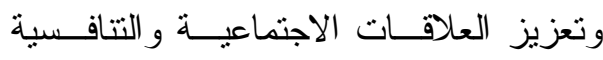
الإيجابية فيما بين المعلمين وبين الطلاب و أن

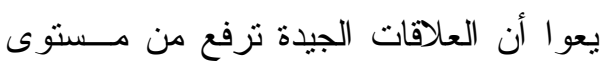
إنجاز هم وتقدير هم، و على المنظومة التربوية

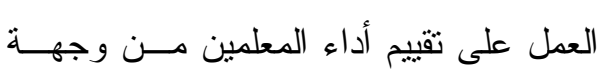

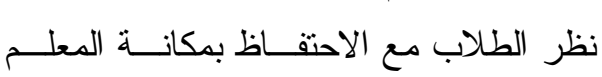

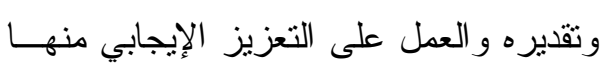
ومعالجة الخلل إن وجد.

كما يرى الباحث أن الإعلام التربوي يقع على عاتقه نولية اهتمام أكبــر بالجــائزة

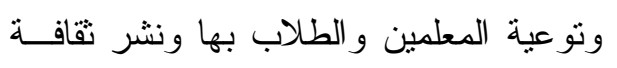
المنافسة الإيجابية للحصول علــى الجــائزة وتغطية الفعالية بشكل أكبر مما يزيد من عدد الإبة لحدول

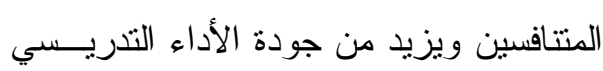
ويكافأ فيه المتميزين معنوياً ومادياً و اجتماعياً

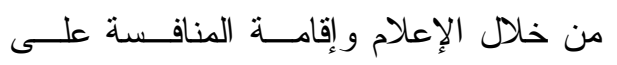

في عملية التتمية الـششاملة و اكتـساب

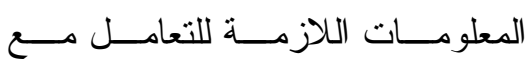
مستحدثات تكنولوجيا التعلـيم مهمـــة

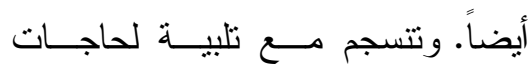

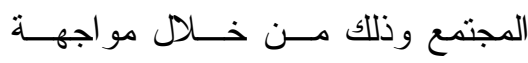
مطالب النمو الاقتصادي والاجتمــاعي الذي يمر به المجتمع، وهذا يتضح من الند خلا أهمية التتمية المهنية في مجــال التخصص و العمل (ص ror). وتتفـق فئه أيضا مع در اسة صنبع (r (

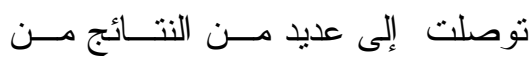
أبرز ها التالي: ارتفاع درجـــة أهميـــة

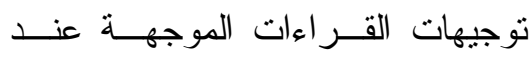

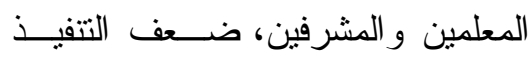
الميداني للقر اءات الموجهة مــن قبـــلـ المعلمين بالر غم من إدر اكهم لأهميتهــا

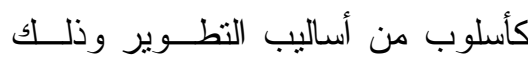
مؤشر لأهمية الحاجة إلى اســتراتيجية

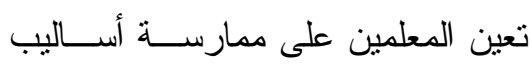

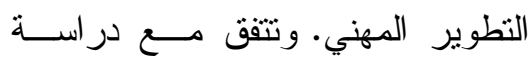

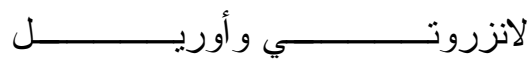
(Lanzerotti \& orr ell،2006) حيث توصلت الدر اسة إلى مجموعــة هانَ من النتائج ومنها أهمية توجيه الطلاب و إرشادهم إلى التخصـــــات المرنيــــة التي نتاسب قدر اتهم العقلية و البدنيـــة، وتكيف الطلاب مع تخصصاتهم المهنية 


$$
\begin{aligned}
& \text { الجائزة.كما أكدت النتيجة أنه مـن خــال ععل الجوائز التحفيزية لا ســيما فـي }
\end{aligned}
$$

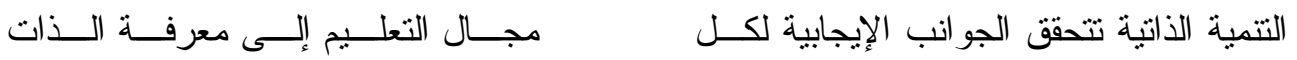

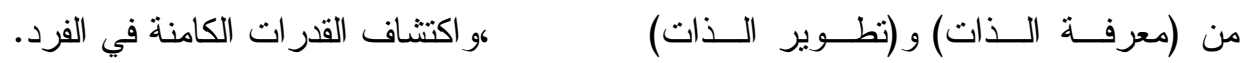

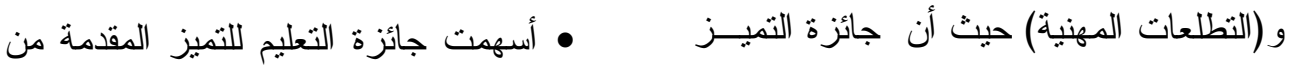

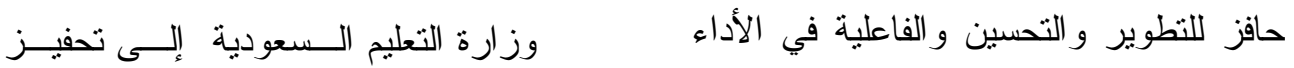

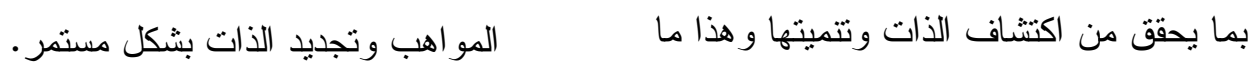

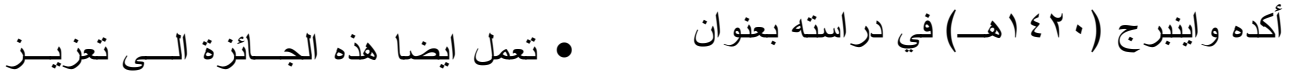

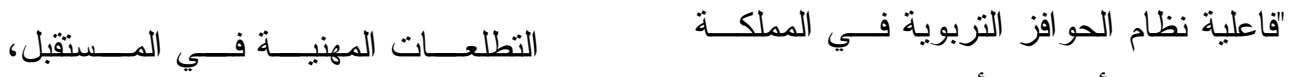

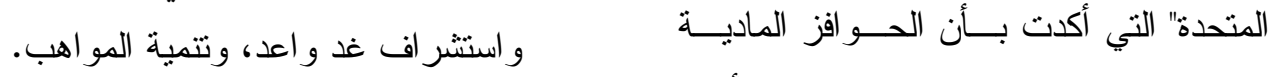

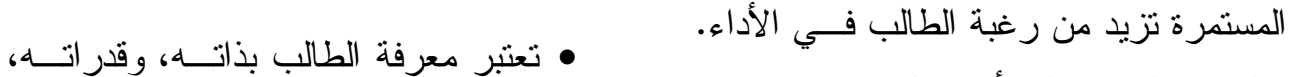

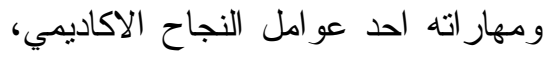

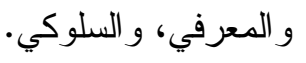

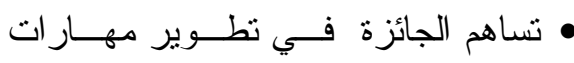

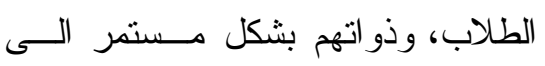

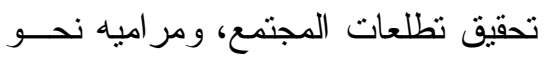

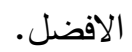

$$
\begin{aligned}
& \text { • تساهم الجـائزة فــي تحقيــق الآمـــال } \\
& \text { و الطموحات التي تتاسب ميول الطـــلاب }
\end{aligned}
$$

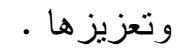

$$
\begin{aligned}
& \text { - توصيات البحث: } \\
& \text { في ضوء النتائج التي توصل إليهـــا البحــث } \\
& \text { يوصي الباحث بما يلي:- } \\
& \text { • ينبغي على المؤسسات التعليمية الاهتمام }
\end{aligned}
$$

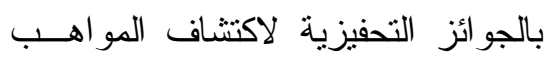

$$
\begin{aligned}
& \text { الكامنة لدى الطلاب. } \\
& \text { ويلخص الباحث إلى أن هنالك علاقة وثثيــــة }
\end{aligned}
$$

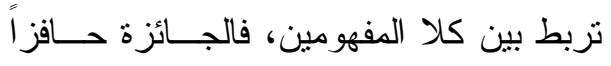

$$
\begin{aligned}
& \text { للأداء المتميز ، وتتجيع الممارسات المتميزة، }
\end{aligned}
$$

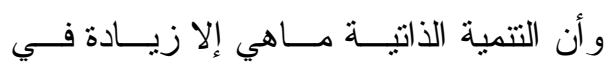

$$
\begin{aligned}
& \text { التحسين و التطوير المستمر للطالب في جميع }
\end{aligned}
$$

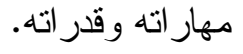

$$
\begin{aligned}
& \text { - نتائج البحث: } \\
& \text { توصلت الدر اسة الى النتائج التالية:- } \\
& \text { • تشكل الجائزة الني تقدمها وزارة التعليم } \\
& \text { بمثابة حافز للتتمية الذاتية، ودعم لتطوير } \\
& \text { المهار ات. } \\
& \text { • يعني تطوير الذات النمو و الثقدم الــذي }
\end{aligned}
$$

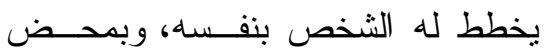

$$
\begin{aligned}
& \text { رغبته و إر ادته لتحقيق أهداف محــدودة، } \\
& \text { وتغيير مستمر بغرض الوصــول إلـى ولى } \\
& \text { مستويات افضل. }
\end{aligned}
$$


• ضرورة أن تكون جوائز التعليم للتميـز

• يجب العمل من قبل إدارة التعليم علـى

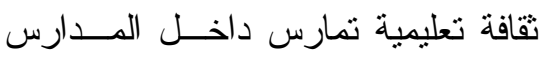

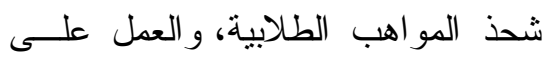

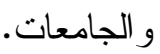

تتمية وتحفيز الذات لدى الطــلاب مـــن

• ينبغي على المعلمين بذل ما بوسعهم من خلال الأنشطة الصفية وللاصفيه.

خلال تقديم الرسالة التعليمية إلى تتميــة

• يجب على كل مكونات المجتــع مـن

الذات الطلابية وتحفيز هم.

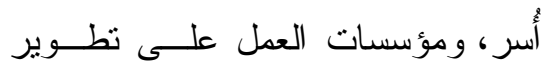

- مقترحات البحث:

ذوات الطلاب، وتعزيز مهار اتهم.

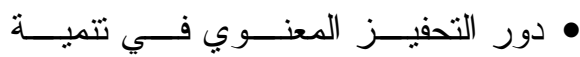

• ينبغي على إدارة التعليم وخاصــة قـسم

المهار ات الاكاديمية لدى الطلاب.

• تأثنير الجوائز التعليمية على رفع معـدل

المو هوبين بمتابعة المو اهب، و اكتــشافها من خلال التحفيز المادي و المعنوي.

التحصيل الاكاديمي لدى الطلاب.

• يجـــب علــى إدارة التعلـــيم الاهتمـــام

• التشكيل السلوكي، و المعرفي لطــلاب لـاب

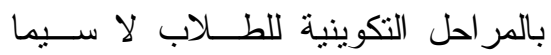

المر احل الثانوية، وتأثيره على مستقبلهم.

المرحلة الثانوية.

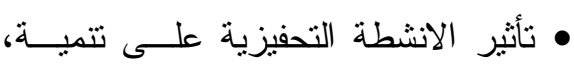

و وتقدير الذات لاى الطلاب .

عالةة معرفة الذات لدى الطلاب بالتفوق

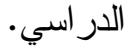

قائمة المصادر والمراجع المانع

القرآن الكريم.

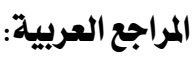

• يجب على المدارس الوقوف على كافة

العقبات، و المعوقات المادية، و النفـــية

الني تعترض جميع الطلاب.

• ينبغي حشد مزيد من الجـــوائز للتميــز

الاكاديمي، و التعليمي بغــرض تفعيـل

المو اهب الكامنة للطلاب ومساعدتهم في لي

ادر الك ذو اتهم.

أبو حماد، ناصر الــدين(9 جـ (ه). الإرشــاد

النفسي والتوجيه المهني. عمان: عالم

• ضرورة تضمين مهار ات تتمية الــذات،

ومعرفتها بالمنهاج الدر اسية التعليمية.

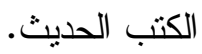

• يجب ان يكون كل طالب ملم، ومدرك

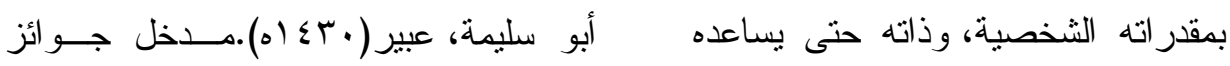

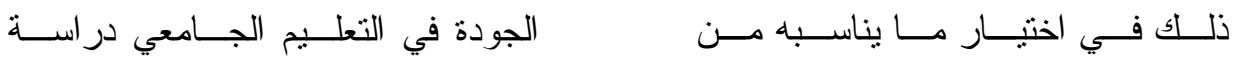

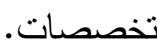


و استثر اف المستقبل. طء: الريــاض: مكتبة الرشد.

خاطر ، تهاني (999 (م). مـشكلات المعلــم

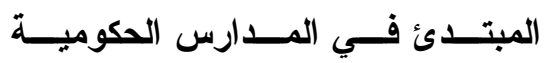

بمحافظات غزة ومقترحسـات حلولهــا.

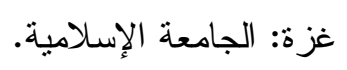

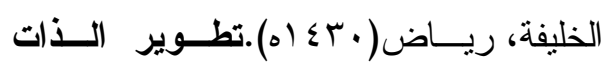

ودوره في تنمية المهـــارات الأمنيــة.

رسالة ماجستير، قسم العلوم الـشرطية،

الرياض: جامعة نايف العربيــة للعلــوم

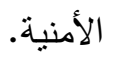

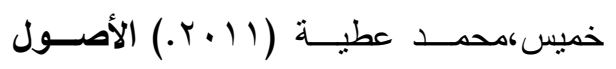

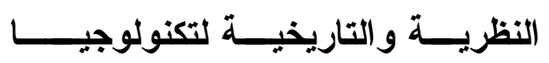

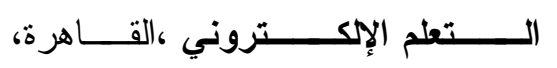

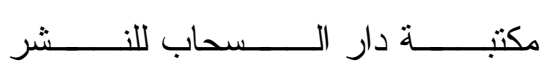
و التوزيع.

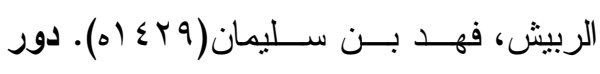

الحوافز في رفع كفاءة أداء العـاملين

في المجال التربوي، رسالة ماجسـنير

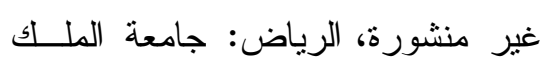

سعود. س سير.

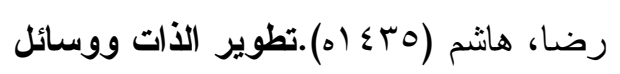

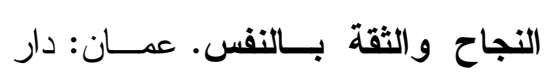
ومكتبة الحادد للتوزيع و النشر .

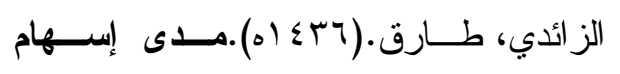

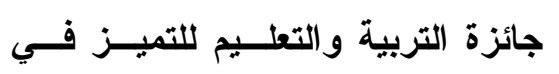

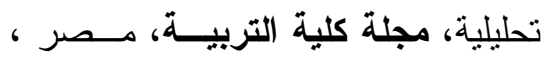

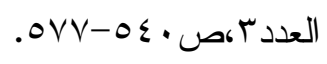

أبو النصر ، مدحت محمــد(اس ـ (ه).إعــادة

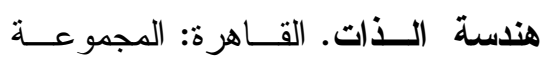

$$
\text { العربية للتنريب و النشر. }
$$

بادويلان، أحمد سالم (0بـ (ه).طور نفـسك

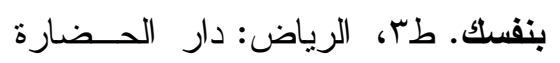

$$
\text { للنشر و التوزيع. }
$$

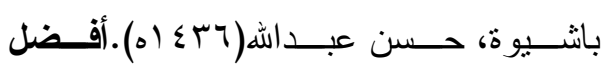

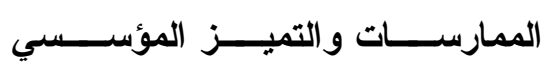

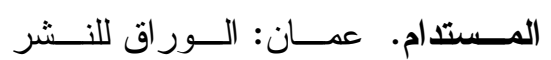
و التوزيع.

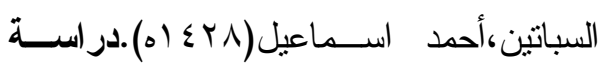

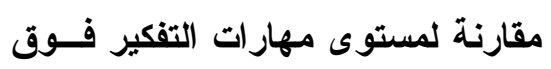

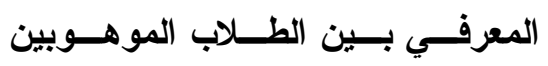
و أقرانهم العاديين بالمرحلة المتوسطة بـان في مدارس مكــة المكرمــة. رســالة ماجستير ،جامعة عمان العربية. التبر، ربيعــة (اباء (ه).خطــوات لتغييـر وتنمية الأات. الرباط: دارة ابي رقر اق رله للطباعة و النشر .

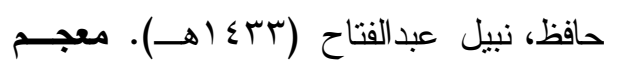
علم نفس النمو ، القاهره: عالم الكتب. الحامد، محمد وزيادة، مصطفى و العتيبـي،

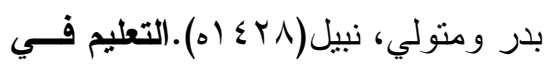

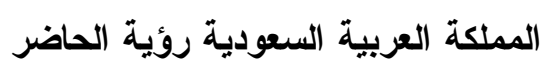


منشورة. الرياض: جامعة نايف العربية لالعلوم الأمنية. شهده، السيد علي السيد (برى اه). المؤتمر العلمي السادس عشر للجمعية المصرية للتربية العلميــة: التربيــة العلميــة.

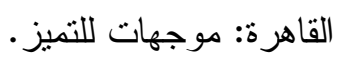

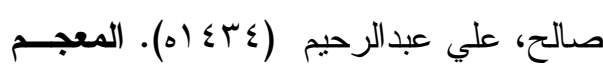
العربي لتحديد المصطلحات النفـسية. عمان: مكتبة الحامد للنشر و التوزيع. صنبع، أحمد بن حسين بن علــي( فT \& (O).

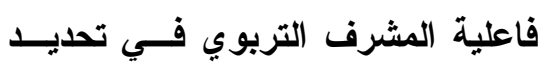
المجالات المعرفية والمهارية للقراءات

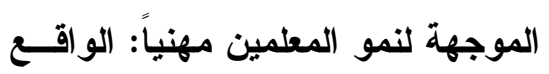

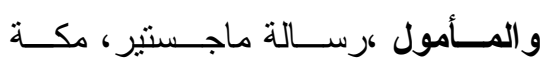
المكرمة: جامعة أم القرى.

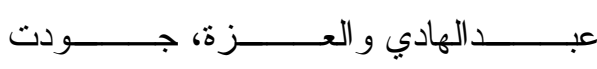

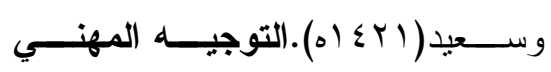

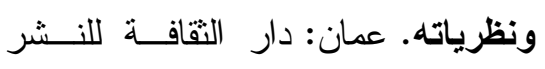
و التوزيع.

العبرية، نعيمة بنت سعيد(س ع (ه). التتميــة

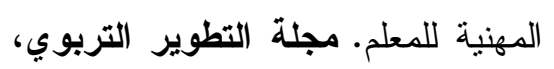

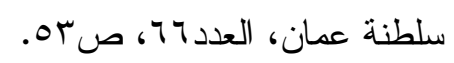

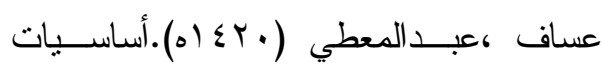

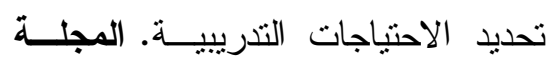
العربية للإدارة ، م(r)، ع(r).
تحسين الأداء الإداري لمديري المدارس

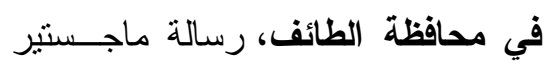

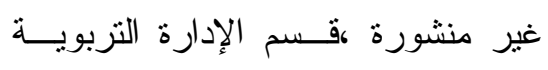
و التخطيط ،كلية التربية ، مكة المكرمة: جامعة أم القرى.

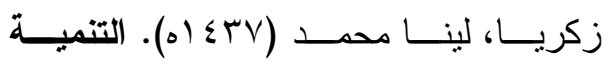
البشرية ومهارات تطوير الأداء و الذات. عمان: دار امجد للنشر و التوزيع. السواط، سامية بنت عيــضة بـن عبــــالله

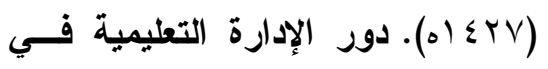
الحوافز التثجيعية لمعلمات المرحلــة لمئة المتوسطة بمدينة مكة المكرمــة بـين

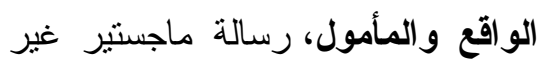

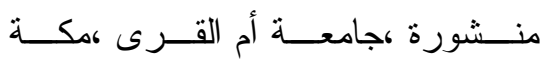
المكرمة.

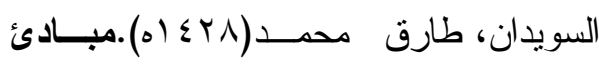

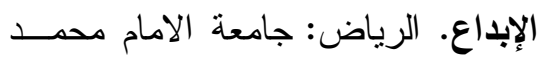

$$
\text { بن سعود الإسلامية. }
$$

الثقاوي ،عبدالرحمن (ع ع اه). التـدريب الإداري للتنمية: دراسة لبرامج التدريب الإعدادي في المملكة العربية السعودية. الرياض: مطابع سمحة.

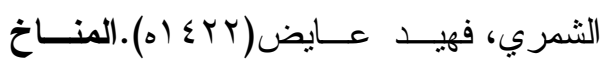
التظيمي في المنافذ الجمركية وعلاقته

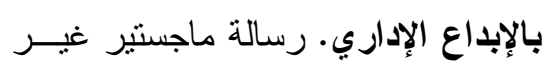


اللغة الاجليزية بمراحل التعليم العسام

في ضوء الواقع والاتجاهات المعاصرة،

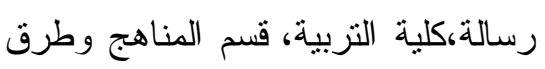

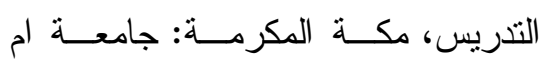

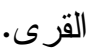

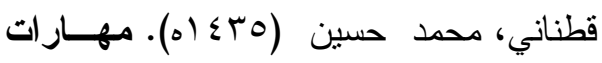
وفن التحفيز.طا، عمان: دار جريــر

$$
\text { للنشر و التوزيع. }
$$

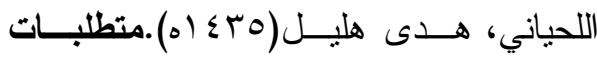

معلمات الثانويات المطورة بمدينة مكة هلئ المكرمة لتفعيل معايير جائزة التعلـيم

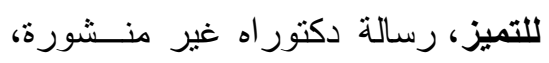
قسم الأصول الإسلامية للتربيــة،كليــة رئة

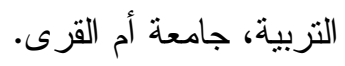

محمد، رجب عبداللظيف (r ؟ اOه). أســرار التميز. المنصورة: دار اليقين للنـشر

$$
\text { و التوزيع. }
$$

محمــود،كــاظم محمــود، ســـهيل ،حسـن

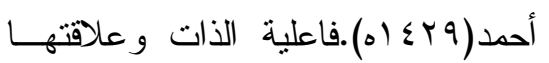
بالسلوك الفوضوي لدى طلاب المرحلة

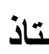

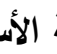

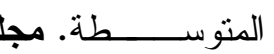
العلمية،(VY)

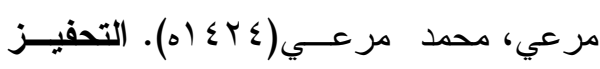
المعنوي وكيفية تفعيله في القطاع العام

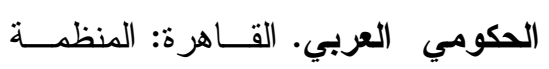
العربية للتتمية الإدارية.

$$
\begin{aligned}
& \text { العساف، صالح (بT\& (ه). المــدخل إلـى } \\
& \text { البحث في العلوم السلوكية. الريــاض: }
\end{aligned}
$$

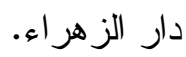

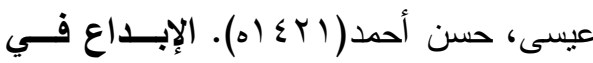

$$
\begin{aligned}
& \text { الفن والعلم. الكويت: المجلس الـــوطني } \\
& \text { للافقة و الفنون و الآداب. }
\end{aligned}
$$

علاونه، عمر محمد(9 و؟ (ه).أثز برنــامج

تعليمي في التربية الإسلامية مستند إلى

تصنيف بلوم للمستويات المعرفية العليا

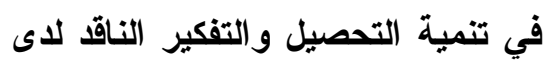

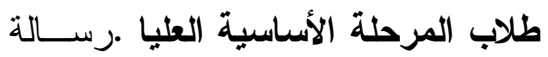
دكتور اه.عمان:جامعة عمــان العربيــة للار اسات العليا.

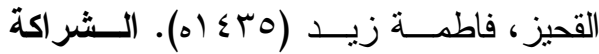
المجتمعية وعلاقتها بالإدارة الذاتية في مدارس تطوير للبنات بمدينة الرياض، رسالة ماجستير، الرياض: جامعة الامام

$$
\text { محمد بن سعود الإسلامية. }
$$

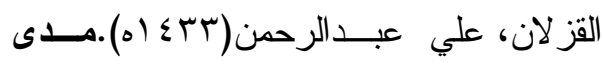
تحقيق معلمي العلوم بالمرحلة الثانوية في مدينة الرس لجودة الأداء التدريسي

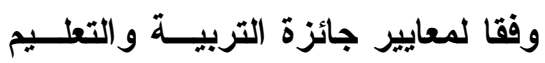

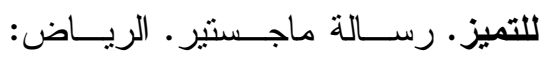
جامعة الامام محمد بن سعود الإسلامية.

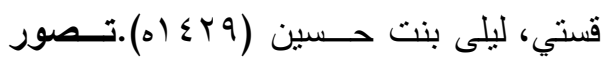
مقترح للتطوير المهني الذاتي لمعلمات 
الودعان، إير اهيم فهـــ (بTـ (ه). عـشرون قاعدة لتطوير ذاتك.

الورثان، عدنان بن أحمد بن راشد، وبنـي دئي

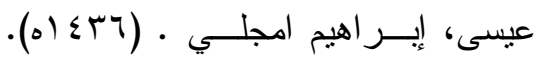

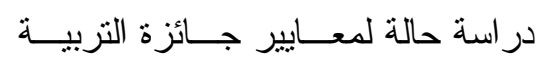

و التعليم للتميز بالمملكة العربية السعودية

في ضوء المعـايير الدوليــة. التربيــة

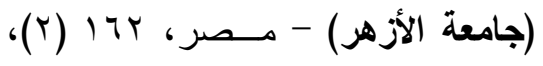

. $\vee 1 \wedge-4 \wedge 9$

وزارة التعليم (10 • rم). الاليل التفـسيري

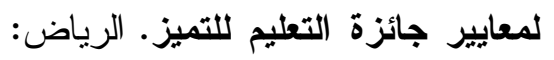

$$
\text { المملكة العربية السعودية. }
$$

المراجع الأجنبية

Agustinus Bandur,(2008).A study of the Implementation of school Based Management in Flores primary schools in lndonesia.

AL_Humaidan,Ibrahim(2012).Impa

ct of the Education Award of Excellence on the Interaction of the field of Education in saudi Arabia,International

Conference for Academic

Disciplines,University of

Nevada,Las Vegas.

Arasaw, S.(2014).Occupational

Aspirations, Expectations,

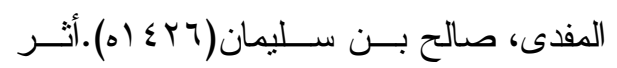

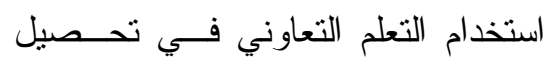

طلاب الصف الثاني الثانوي لمادة الفقه.

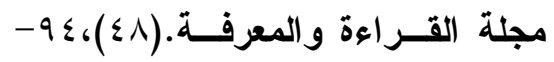

.) $\leqslant \varepsilon$

ملحم، سامي محمد(بT\& (ه).مبادئ التوجيه

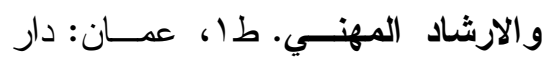

الإعصار العلمي للنشر و التوزيع.

المنصور ، زهير(0 . ـ (ه).مقدمة في منهج

الإبداع. الكويت: دار ذات السلاسل.

ناصر ، إبــر اهيم.(د.ت). علــــ الاجتمـــاع التربوي، بيروت: دار الجيل.

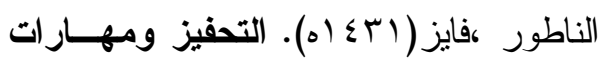
تظوير الذات. عمان: دار أسامة للنـشر وائر و التوزيع.

هارلود، فيونا ( •r؟ (ه). الخطوات الـسبع

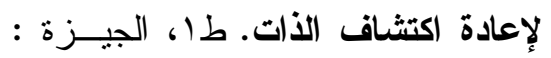
دار الفاروق للاستثمار الثقافة..

الهلالات، صالح علي(0بـ (ه).إدارة التميز. عمان: و ائل للنشر و النوزيع.

هيجان، عبد الرحمن بـن أحمــد (9 (1) (ه).

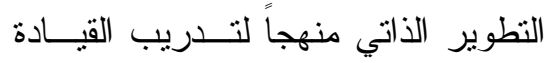

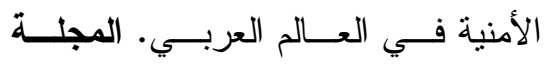

العربية للاراسات الأمنية والتـدريب،

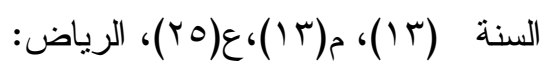

جامعة نايف العربية للعلوم الأمنية.

And Occupational Prestige 
in Education \& Technology, 3

(2), 56-58.

Domenico, M. \& Karen, H. (2007).

Career Aspiration of

Pregnant and Parenting

Adolescents. Journal of Family

and Consumer Sciences

Education, 25(1),24-33.

Jensen,M. (2010). The Impact of

Self-Knowledge on the

Leadership Practice of

Educators. Ph.D, University of

ST. Thomas.

Knappik,F.

(2015). Self-

knowledge about attitudes:

rationalism

meets

interpretation. Philosophical

Explorations , 18 (2), 183-198.

Langland-Hassan,p. (2015). Self-

knowledge and imagination.

Philosophical Explorations,

18 (2), 226-245.

Lanzerotti,m.\& orrell,j.(2006). The

aps professional development

resource guide,aps committee

on careers and professional

development one physics

ellipse .college park,uk.
Judgments Of Preparatory

School Adolescents In Addis

Ababa. Ph.D , Addis Ababa

University.

Bora,B. (2016). Educational and

Occupational Aspiration In

Relation To School

Environment of the

Secondary School Students of

South Kamrup Area of

Assam- A Study. The International Journal of Indian

Psychology, 4 (82), 141-1161.

Creed, P., Wong, O, Hood, M. (2009). Career decisionmaking, career barriers and occupational aspirations in

Chinese adolescents.

International Journal for

Educational and Vocational

Guidance, 1-28.

Das,A \& Bhagabati, N. (2016). A Study on Occupational Aspiration of Higher Secondary Girls Students in Nagaon District. International Journal of Advanced Research 


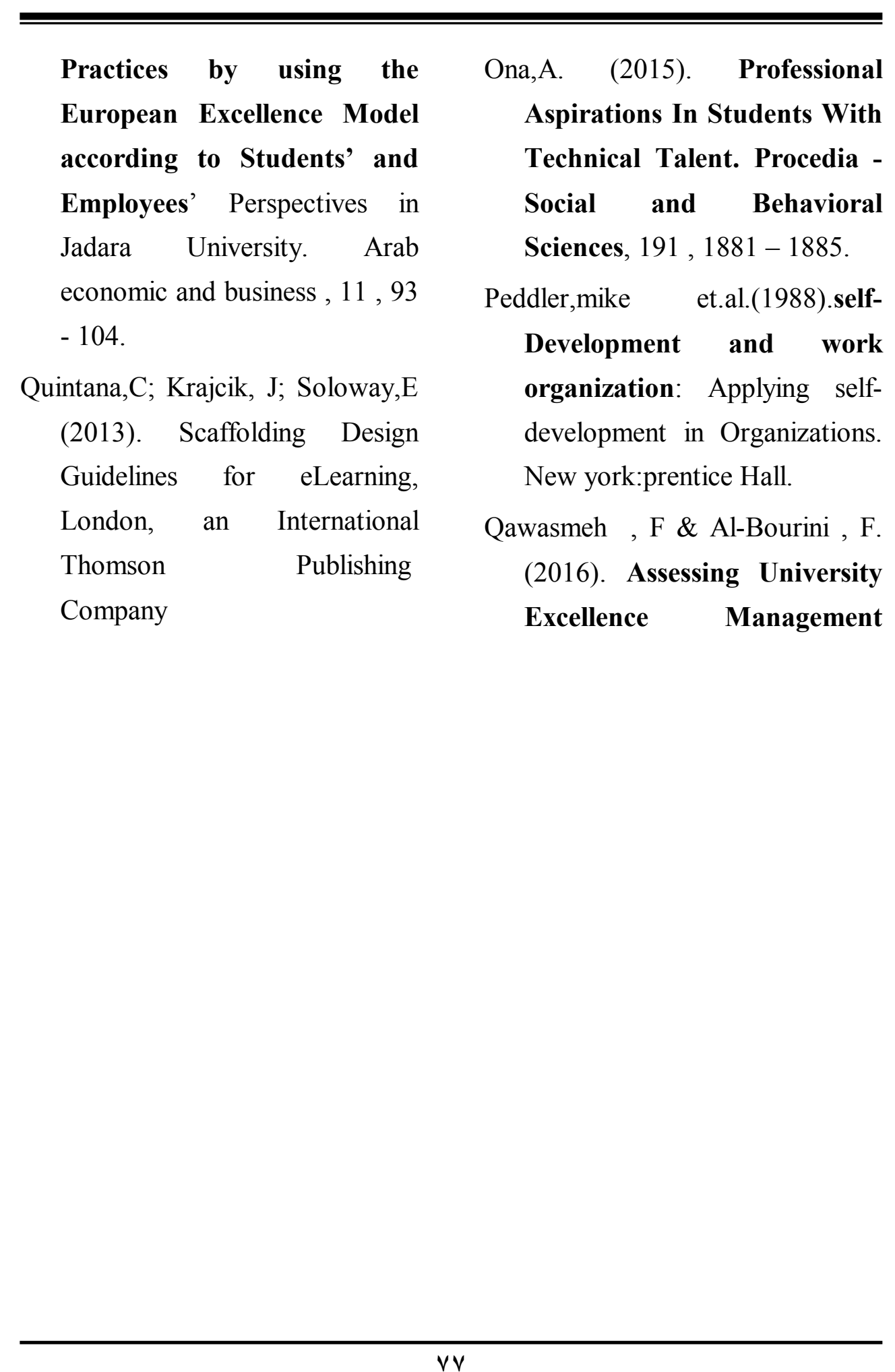

